\title{
Desiccant Contamination Research: Report on the Desiccant Contamination Test Facility
}

\author{
SERI/TP- $-254-3457$
}

DE91 002193

Ahmad A. Pesaran

Carl E. Bingham

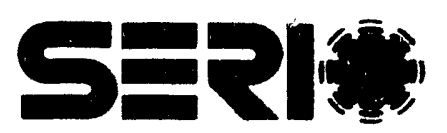

Solar Energy Research Institute 1617 Cole Boulevard

Golden, Colorado 80401-3393

A Division of Midwest Research Institute Operated for the U.S. Department of Energy under Contract No. DE-ACO2-83CH10093

Prepared under task No. SB811141

July 1991 


\section{NOTICE}

This report was prepared as an account of work sponsored by an agency of the United States government. Neither the United States government nor any agency thereof, nor any of their employees, makes any warranty, express or implied, or assumes any legal liability $r$ responsibility for the accuracy, completeness, or usefulness of any information, apparatus, product, or process disclesed, or representm that its use would not infringe privately owned rights. Reference herein to any specific commercial product, process, or senvice by trade name, trudemark, manufacturer, or othenwise does not necessarily constitute or imply its endorsement, recommendation, or favoring by the United States government or any agency therect. The views and opinions of authors expressed herein do not necessarily state or reflect those of the United States government or any agency inereot.

Printed in the United States of America

Available from:

National Technicis! Information Service

U.S. Department of Commerce

5285 Port Royal Road

Springfield, VA 22161

Price: Microfiche A01

Printed Copy A06

Codes are usio for pricting all publications. The code is determined by the number of pages in the publication. Information pertaining to the pricing codes

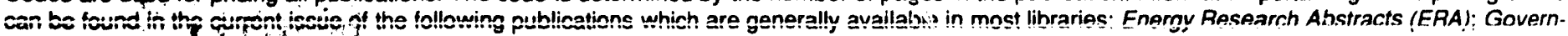
ment Reports Ambuhcements and Index (GRA and I); Scientific and Technical Abstract Reports (STAR); and publication NTIS-PR-360 available from NTIS at the above address. 


\section{PREFACE}

In keeping with the national energy policy goal of fostering an adequate supply of energy at a reasonable cost, the U.S. Department of Energy (DOE) supports a variety of programs to promote a balanced and mixed energy resource system. The mission of the DOE Solar Buildings Research and Development Program is to support this goal, by providing for the development of solar technology alternatives for the buildings sector. It is the goal of the Program to establish a proven technology base to allow industry to develop solar products and designs for buildings which are economically competitive and can contribute significantly to building energy supplies nationally. Toward this end, the program sponsors research activities related to increasing the efficiency, reducing the cost, and improving the long term durability of passive and active solar systems for building water and space heating, cooling, and daylighting applications. These activities are conducted in four major areas: Advanced Passive Solar Materials Components and Systems Research, Collector Technology Research, Cooling Systems Research, and Systems Analysis and Applications Research.

Advanced Passive Solar Materials Components and Systems Research-This activity area includes work on new aperture materials for controlling solar heat gains, and for enhancing the use of daylight for building interior lighting purposes. It also encompasses work on low-cost thermal storage materials that have high thermal storage capacity and can be integrated with conventional building elements, and work on materials and methods to transport thermal energy efficiently between any building exterior surface and the building interior by nonmechanical means.

Cooling Systems Research-This activity area involves research on high performance dehumidifiers and chillers that can operate efficiently with the variable thermal outputs and delivery temperatures associated with solar collectors. It also includes work on advanced passive cooling techniques.

Systems Analysis and Applications Reseanch-This activity area encompasses experimental testing, analysis, and evaluation of solar heating, cooling, and daylighting systems for residential and nonresidential buildings. This involves system integration studies, the development of design and analysis tools, and the establishment of overall cost, performance, and durability targets for various technology for system options.

This report describes the work conducted to improve the durability of solid desiccant dehumidifiers by investigating the causes of degradation of desiccant materials from airborne contaminants and thermal cycling. The performance of a dehumidifier strongly depends on the physical properties and durability of the desiccant material. To make durable and reliable dehumidifiers, an understanding is needed of how and to what degree the performance of a dehumidifier is affected by desiccant degradation.

This report, an account of work under Cooling Systems Research, documents the efforts to design and fabricate a test facility to investigate desiccant contamination based on industry and academia recommendations. It also discusses the experimental techniques needed for obtaining high-quality data and presents plans for next year. Researchers of the Mechanical and Industrial Technology Division performed this work at the Solar Energy Research Institute in FY 1988 for DOE's Office of Solar Heat Technologies. 
The assistance of Centennial Engineering Inc., Behrent Engineering Company, MeycrWeddle Company, Fidus Instrument Corporation, and SERI's Facilitics Branch, particularly B. McCoy, is greatly appreciated.

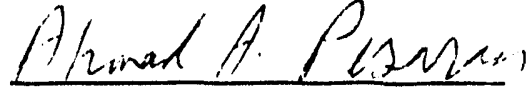

Ahmad A. Pesaran

Task Leader

Approved for

SOLAR ENERGY RESEARCH INSTITUTE

$\frac{\text { Terry R. Penney, Manager }}{\text { Thermal, Fluid, and Optical Sciences Branch }}$

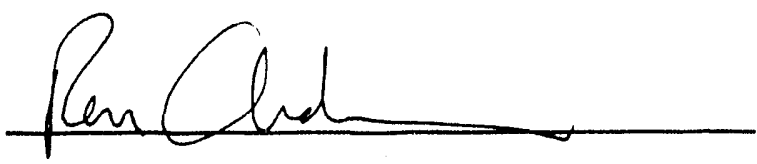

R. Anderson, Program Leader

Building Energy Technology Program

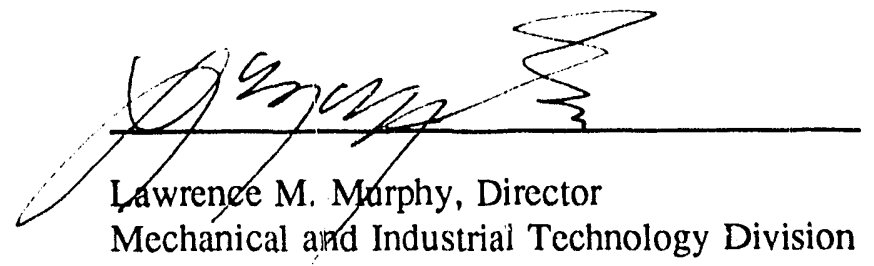




\section{SUMMARY}

The objective of this project is to fabricate a test facility to investigate the impact of desiccant contamination from airborne pollutants on the sorption properties of desiccant materials. The results will be used to estimate the impact of desiccant degradation on the performance of solar desiccant cooling systems. This report focuses only on the effort to build the desiccant contamination test facility. The experimental results are documented in FY 1989/1990 reports.

In FY 1987, we designed a desiccant contamination test facility based on the recommendations of the desiccant Materials Contamination Workshop hosted by DOE in June 1987 and on general experimental requirements for desiccant cooling applications. We also took into consideration the use of our existing experimental facilities, quality of data, and cost of fabrication and operation.

The facility is designed to expose desiccant samples in a test cell to air charged with airborne contaminants (cigarette smoke was the first contaminant of choice). In a second test cell, similar desiccant samples are exposed to pollutant-free air, i.e., no exposure to pollutants. The samples are also subjected to thermal and moisture cycles that desiccant materials experience during actual operation of desiccant dehumidifiers. The samples can be removed periodically to measure their sorption properties. Any difference between the samples processed with clean or polluted air is attributed to contamination and thermal cycling.

A local engineering firm, Centennial Engineering Inc., assisted us in detailed engineering design (mechanical and electrical) and cost estimation of the facility. In FY 1988, Centennial's initial engineering drawings of the desiccant contamination test facility were revised after internal and external reviews. The external reviews were provided by the DOE Solar Cooling Program Peer Review conducted at SERI on February 17, 1988. The internal reviews were provided by the SERI desiccant team and members of the SERI Facilities Branch. After incorporating these reviews in the engineering design of the facility, Centennial provided final mechanical and electrical drawings and design of the facility.

In October 1988, following a competitive procurement process, we contracted with a local enginecring firm, Meyer-Weddle Company, to fabricate the facility based on the final design. The mechanical and electrical fabrication, started in November 1988, was completed in January 1989.

In addition to designing and fabricating the facility and contaminating desiccant materials, we contacted several manufacturers of smoking machines for fabrication of a fresh cigarette smoke generator. Based on its expertise and qualifications, we contracted with Fidus Instrument Corporation to build a smoking machine for our unique application. The machine will generate cigarette smoke at a rate of six cigarettes per hour for 24 hours in one day. The design and fabrication began in the first week of December 1988. Fidus delivered and installed the smoking machine in March 1989.

To control, monitor, and record the operating parameters of the test facility, we assembled hardware and software for a data-acquisition system. The system was made operational by May 1989 . A gas chromatograph is in place to measure the concentratic $n$ of the gaseous pollutants in the test cells.

We have also identified the experimental procedure to obtain high-quality data. After the desiccant samples are exposed intermittently to clean and polluted air, they are removed from the test cells at predetermined intervals for measurement of their sorption properties. These sorption properties include the moisture capacity and rate, measured by a gravimetric technique in the SERI sorption test facility; the elemental composition and oxidation states of surface components on the internal surfaces of desiccants, measured by SERI surface analysis equipment (e.g., x-ray photoelectron spectroscopy and scanning electron microscopy); and surface area, pore volume, and pore size distribution of desiccants, measured 
using the mictometric techniques of commercial laboratories. The components adsorbed into the internal surfaces of desiccants will be analyzed using residual gas analyzers. Gas chromatography and nitrogen cold finger techniques will be used to analyze the components present in the airstreams.

The contamination experiments were started in mid-August 1989 and were completed in July 1990. We prepared a draft report documenting the interim findings of the contamination experiments in January 1989, as part of FY 1989 activities and later in December 1990 as part of FY 1990 activities. 


\section{TABLE OF CONTENTS}

$\underline{\text { Page }}$

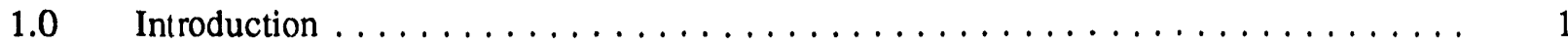

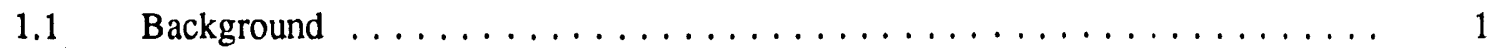

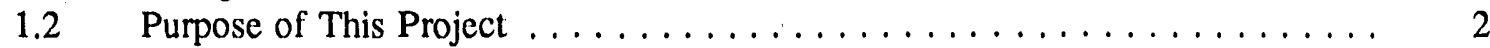

2.0 Description of the Desiccant Contamination Test Facility $\ldots \ldots \ldots \ldots \ldots \ldots$

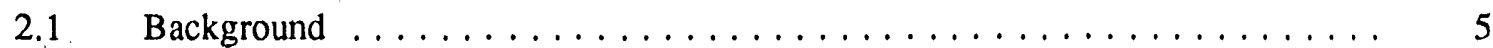

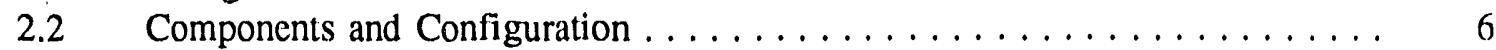

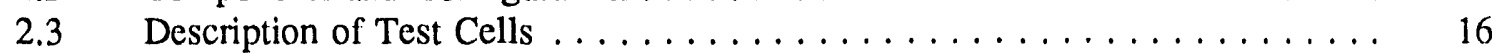

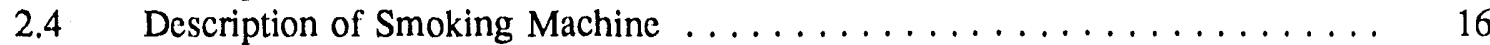

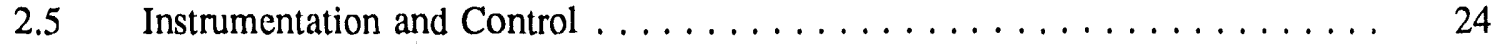

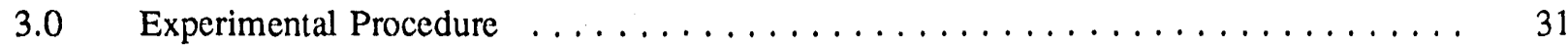

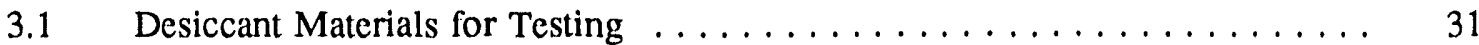

3.1.1 Number of Desiccants to be Tested . . . . . . . . . . . . . . . 31

3.1.2 Materials Considered ...................... 31

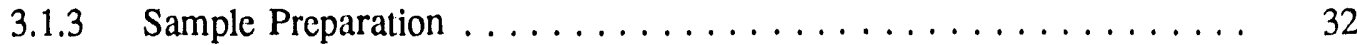

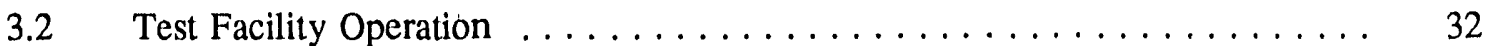

3.3 Desiccant Material Characterization $\ldots \ldots \ldots \ldots \ldots \ldots \ldots \ldots \ldots$

3.3.1 Capacity Measurements . . . . . . . . . . . . . . . . . 34

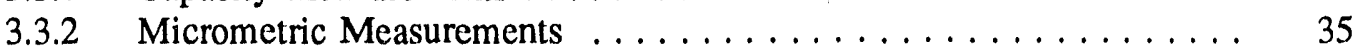

3.3.3 Surface Analysis . . . . . . . . . . . . . . . . . 35

$4.0 \quad$ Future Work $\ldots \ldots \ldots \ldots \ldots \ldots \ldots \ldots \ldots \ldots \ldots \ldots \ldots \ldots$

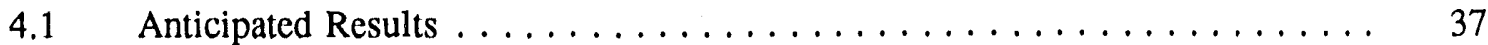

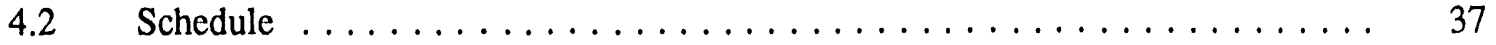

$5.0 \quad$ References $\ldots \ldots \ldots \ldots \ldots \ldots \ldots \ldots \ldots \ldots \ldots \ldots \ldots \ldots \ldots \ldots$

Appendix A. Viewgraphs of FY 1988 Presentation to DOE Solar Desiccant

Cooling Peer Review . ...................... A-1

Appendix B. Electrical Diagrams of the Desiccant Contamination

Test Facility . . . . . . . . . . . . . . . . . . . .

Appendix C. Selected Distribution List $\ldots \ldots \ldots \ldots \ldots \ldots \ldots \ldots \ldots \ldots \ldots \ldots \ldots$ 


\section{LIST OF FIGURES}

1-1 Roadmap to the problem of desiccant contamination $\ldots \ldots \ldots \ldots \ldots$

2-1 Schematic of desiccant contamination test facility $\ldots \ldots \ldots \ldots \ldots \ldots$

2-2 Desiccant contamination test facility flow sheet $\ldots \ldots \ldots \ldots \ldots \ldots$

2-3 Flow diagram of desiccant contamination test facility during clean test cell adsorption (contamination test ccll

regeneration) cycle. No flow through dashed line.

2-4 Flow diagram of desiccant contamination test facility during contamination test cell adsorption (clean test cell regeneration) cycle. No flow through dashed line.

2-5 Desiccant contamination test facility general arrangement-plans

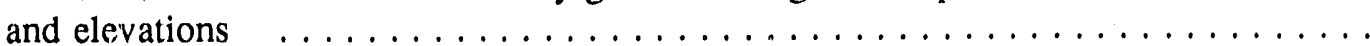

2-6 Desiccant contamination test facility layout in desiccant cooling laboratory

2-7 Photograph of the desiccant contamination test facility

2-8 Details of desiccant test cell $\ldots \ldots \ldots \ldots \ldots \ldots \ldots \ldots \ldots \ldots \ldots \ldots$

2-9 Sample test tube with silica gel and screens $\ldots \ldots \ldots \ldots \ldots \ldots$

2-10 Photograph of an uninsulated test cell $\ldots \ldots \ldots \ldots \ldots \ldots \ldots \ldots \ldots \ldots$

2-11 Photograph of desiccant test cell (open) showing sample holder sleeves

2-12 Photograph of smoking machine $\ldots \ldots \ldots \ldots \ldots \ldots \ldots \ldots \ldots \ldots$

2-13 Desiccant contamination test facility P\&ID flow sheet showing control strategies and instrumentation .

2-14 Sensor locations :or data-acquisition system $\ldots \ldots \ldots \ldots \ldots \ldots \ldots \ldots$

2-15 Data-acquisition system flow chart ...................... 29

2-16 Photograph of data-acquisition system hardware running LabTech

Notebook software

3-1 Cross section of tesi cells, showing sample tube locations

4-1 Anticipated hypothetical results from the desiccant 


\section{LIST OF TABLES}

Page

4-1 Schedule of Activiti's to Perform for Desiccant Contamination

Research in 1989

$y$ 


\subsection{INTRODUCTION}

\subsection{Background}

Open-cycle desiccant cooling and dehumidification systems have received considerable attention from public and private organizations in the past several years. They are considered alternatives or supplements to conventional vapor compression machines for air conditioning of buildings and spaces with high latent loads. The desiccant material in a dehumidifier removes the moisture from the process air to be dried. The desiccant is regenerated later with air heated by an energy source: the sun, natural gas, or electricity.

The cost, efficiency, and reliability (or durability) of a desiccant cooling system depend on its components. A desiccant dehumidifier is a major component in the system. After several years of research and development, the cost, efficiency, and size of solid desiccant dehumidifiers have improved by a factor of two, and further improvements are being pursued through cooperation with industry. The reliability of desiccant dehumidifiers is also of concern, particularly the degradation of the desiccant material.

In FY 1984, the ASHRAE SP-48 committee revie'w of DOE's Active Heating and Cooling FY 1984-1988 Research Plan noted strong concern regarding the historical problems with contamination of desiccant beds in field operation. Desiccant degradation has been observed in industrial applications in which the process stream contains high concentrations of harsh pollutants. However, the degradation may be less for commercial and residential air conditioning applications in which the concentration level of pollutants may be quite low, especially for ventilation cycle systems.

In any case, there are limited quantitative data in the open literature on the effects of contaminants on desiccants for cooling applications. In a literature search (Pesaran et al. 1986), only two pertinent investigations on desiccant contamination were found: Farouk, Brusewitz, and Bloome (1980) found that the rate of moisture adsorption of three desiccants (molecular sieves, alumina, and silica gel) was reduced by the presence of $5 \%$ dust, typically found in agricultural grain-processing areas. However, they found that dust particles did not affect the equilibrium moisture capacity of the desiccants. Moseman and Bird (1982) carried out experiments for desiccant dehydration of natural gas and fcund that, after only 284 regenerations, the silica gel capacity dropped by almost 20\%. Fesaran et al. (1986) also established methods to measure sorption degradation of contaminated solid desiccants (using a gravimetric technique) and to determine the identity and nature of the contaminants (using a surface analysis technique). To date, no results from a controlled desiccant contamination experiment for air-conditioning applications have been published.

In FY 1987, in ouder to address the issue of desiccant contamination, we started an in-depth engineering investigation. We found that although most desiccant investigators believe contamination will not be a problem, few if any quantitative data exist on the subject in the open literature. To address the problem of desiccant contamination, we proposed a roadmap (Figure 1-1). In June 1987, we presented the results of our literature and analytical studies to the participants of the Desiccant Materials Contamination Workshop hosted by DOE in Washington, D.C. The participants were from academia, industry, and public organizations. The major recommendations of the workshop were that controlled contamination experiments and base-case and worst-case experiments are needed.

In the base case, desiccants are cycled between absorption and regeneration temperatures with clean humid air. In the worst case, desiccants are cycled between two temperatures with humid air that is charged with cigarette smoke (probably the worst pollutant in a residential environment). In each case, after defined periods of testing (up to 10 months) the desiccants are removed and their sorption properties measured. 


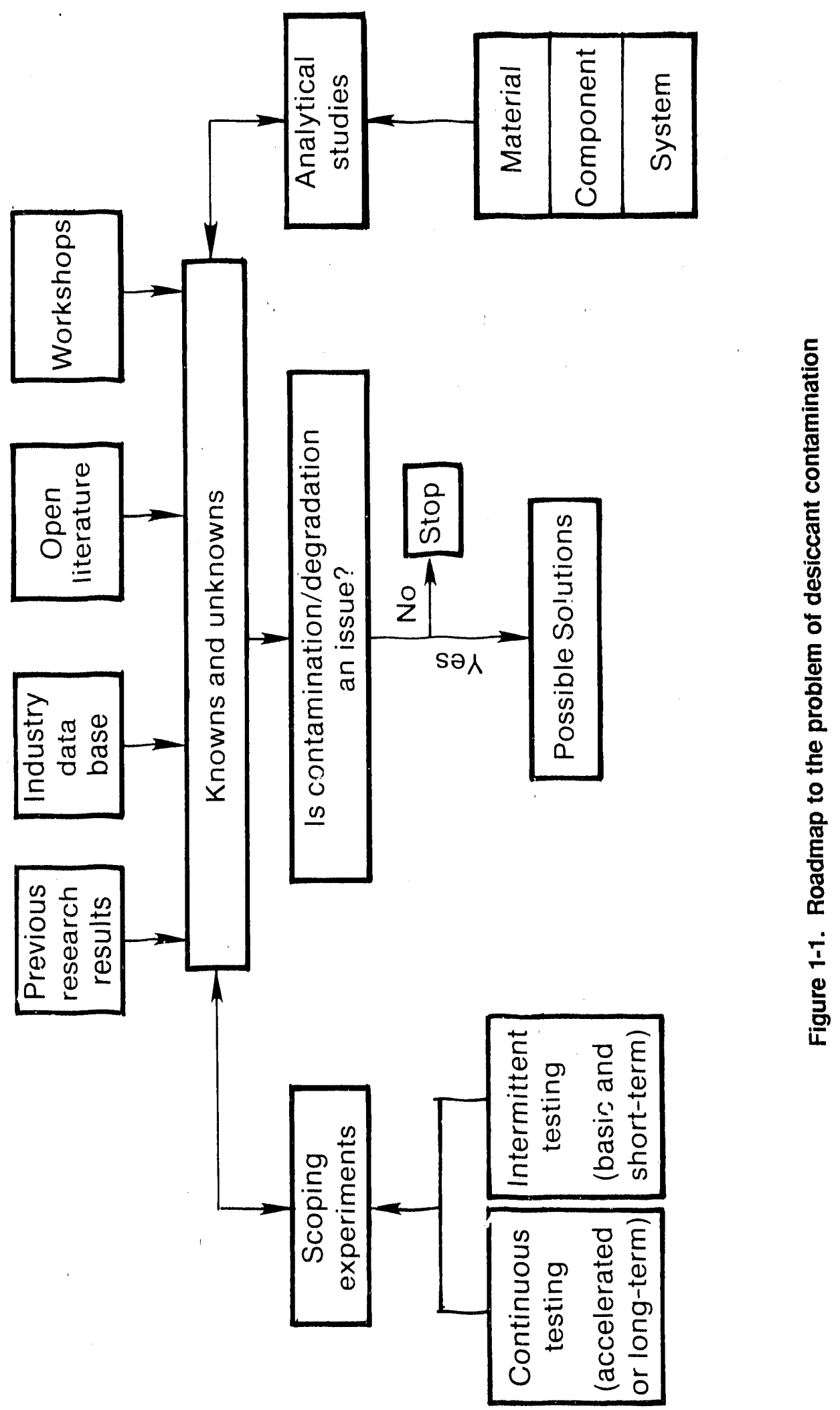


The differences between the virgin (a sample not thermally cycled or exposed to ambient air), base-case, and worst-case samples provide data on degradation caused by thermal cycling and contaminants. Pesaran (1987) presented the results of the workshop and the preliminary analysis.

Based on a preliminary system performance study, we found that desiccant degradation may have a significant impact (up to $40 \%$ reduction) on a desiccant cooling system's performance (Pesaran and Parsons 1987). Performance reduction was dependent on the hypothesis for desiccant degradation over time. Experimental data are needed to evaluate reaiistic degradation effects.

Using the workshop recommendations, general experimental requirements for desiccant cooling applications, our existing experimental facilities, quality of data, and cost issues, we decided to design and fabricate a desiccant contamination test facility (Pesaran and Parsons 1987). We proposed a conceptual design and contracted with Centennial Engineering to assist us in a detailed mechanical and electrical design and cost estimation of the facility. The 1987 Solar Cooling Peer Review concurred with our approach and our proposed conceptual design. Comments from the peer review about the analysis methods and facility design were carefully studied, and action was taken to incorporate them. Appendix A provides the viewgraphs of our presentation at this review meeting and contains information on the investigation we performed in FY 1987.

\subsection{Purpose of Thls Project}

The overall (long-term) objective of this research is to improve the durability and reliability of desiccant dehumidifiers for solar cooling applications. To achieve this objective, experimental data are needed to quantify the impact of airborne pollutants on desiccant materials in dehumidifiers.

The specific objective of this project was to fabricate a test facility to investigate the impact of contamination from airborne pollutants on the sorption properties of desiccant materials. The results from the experiments done in the facility can be used to estimate the impact of desiccant degradation on the performance of solar desiccant cooling systems. In this report we present the final design of the facility; instrumentation, experimental operation, and required material measurements; and future activities. 


\subsection{DESCRIPTION OF THE DESICCANT CONTAMINATION TEST FACILITY}

\section{1 r lckground}

The recommendations of the DOE 1987 Desiccant Materials Contamination Workshop (Pesaran 1987) were the basis for the final design of the desiccant contamination test facility. As discussed in Section 1.0, two types of experiments were recommended:

Base Case in which a desiccant is cycled between absorption and regeneration tempe 'atures with clean humid air.

Worst Case in which the desiccant is cycled between the absorption and regeneration temperatures with humid air that is charged with cigarette smoke (probably the worst pollutant in a residential environment).

In each. case, after predetermined periods of testing, the desiccant is removed and its sorption propertics are measured. The differences among the virgin, clean, and contaminated samples provide data on degradation from thermal cycling and contamination. Testing should be done for a sufficient period of time, at least 10 months. Fresh cigarette smoke was recommended by the workshop participants as the worst pollutant because it has both gaseous and particulate constituents which may be harmful to desiccants. Cigarette smoke is a "soup" of many components found as indoor air pollutants; see Appendix A for the composition or the smoke. After the initial screening it was suggested that indoor contaminants such as cooking oils also be used as the pollution source. We decided to conduct these preliminary experiments to see if even in the worst, case measurable degradation exists.

In addition to the workshop recommendations, we considered other requirements for the needed experiments (Pesaran and Parsons 1987). These include data useful for solar desiccant cooling applications, cost effectiveness, quality of data, and conclusiveness of results. Considering the operating conditions for a typical solar cooling application, the following experimental conditions are required:

Adsorption temperature:

Regeneration temperature:

Air humidity ratio:

Cycle between adsorption and regeneration:

Air face velocity: $30^{\circ} \mathrm{C}$ to $40^{\circ} \mathrm{C}$

$65^{\circ} \mathrm{C}$ to $95^{\circ} \mathrm{C}$

0.010 to $0.016 \mathrm{~kg}$ water $/ \mathrm{kg}$ dry air

1 to 10 minutes

0.4 to $1.5 \mathrm{~m} / \mathrm{s}$

Also, the pollutant concentrations should be typical of those found in residential and commercial buildings. The maximum smoke concentration was found to be $6 \mathrm{mg} / \mathrm{m}^{3}$ of total particulate matter. In addition, multiple desiccant samples were needed for testing different desiccants.

The purpose of the desiccant contamination experiment is to degrade desiccant samples under typical solar desiccant conditions (stated above), in a controlled manner, so that the time history of degradation is known. Measurements to quantify degradation in sorption properties can be done elsewhere.

We compared the above requirements with the existing experimental facilities at SERI and elsewhere and could not find an experimental apparatus that met all the requirements and would provide satisfactory results (Pesaran and Parsons 1987). We decided to fabricate a desiccant contamination test facility based on our requirements. We identified the specifications of the facility as follows: 
- Two fixed test cells, each containing 64 desiccant samples: one test cell for base-case experiments and the other for worst-case experiments

- Two air streams at either adsorption or regeneration temperatures for each test cell

- Air flow rate of each air stream set at $20 \mathrm{crm}(9.5 \mathrm{~L} / \mathrm{s})$

- Multiple desiccant samples

- Average regeneration temperature at $85^{\circ} \mathrm{C}$

- Average adsorption temperature at $35^{\circ} \mathrm{C}$

- Average air humidity at $0.014 \mathrm{~kg}$ water $/ \mathrm{kg}$ dry air

- Filtered ambient air for base case

- Cigarette smoke at burn rate of six cigarettes per hour for worst case

- 24 hours per day operation for at least 10 months.

Based on these specifications we designed a test facility. Centennial Enginecring prepared the detailed mechanical and electrical engineering design and cost breakdown of the facility. We presented the results of our FY 1987 efforts to the 1987 Solar Cooling Peer Review in February 1987. They concurred with the conceptual design of our proposed test facility. They also provided a few comments that were incorporated into the final design of the facility. For example, they suggested testing several different desiccant samples. To accommodate this, we increased the number ve sample holders in each test cell to 100 from 64 . The initial design was reviewed internally by the SERI desiccant team and members of the SERI Facilities Branch to assure proper, dependable, and safe operation of the facility. After incorporating these reviews, the design was finalized and Centennial provided final mechanical and electrical design drawings.

In October 1988, following a competitive procurement process, we contracted with a local engineering firm, Meyer-Weddle Company, to fabricate the facility based on the final design. The electrical and mechanical fabrication began in November 1988 and was completed in January 1989.

In the following sections we discuss descriptions of the test facility, test cells, instrumentation and control, and the sme, king machine.

\subsection{Components and Configuration}

The desiccant contamination test facility consists of two test cells containing 100 sample holders, two heaters, air filters, a humidifier, a smoking machine, and an air blower. Instrumentation is provided to measure the air flow rates, air temperature, pressure, and air humidity at several locations. The components are connected via 3-in., 2-in., or 1.5-in. galvanized steel pipes with screwed fittings. All the components of the facility are cleaned with appropriate solvents to make them oil and particulate frec. The internal areas of the facility were purged with cleaning foam after completion of the fabrication.

Figure 2-1 is a schematic of the facility, and Figure 2-2 shows its detailed flow sheet. Ambient air cnters through a silencer air filter to remove particulate matter. A steam humidifier (Model VPC-2, manufactured by DRI-STEEM) injects water vapor into the air stream to bring the air humidity to a desired level (typically $0.014 \mathrm{~kg}$ water $/ \mathrm{kg}$ dry air). The $208-\mathrm{V}$, single-phase humidifier generates a maximum of $2.6 \mathrm{~kg} / \mathrm{hr}$ steam and has a time-proportional module for stand-alone control via feedback from a dewpoint hygrometer.

After steam is injected, the air flow rate is measured by a flowmeter. The humid air then branches into two lines. Each line contains a flowmeter, an electrically actuated butterfly valve, and a feedback control mcchanism to provide about $20 \mathrm{cfm}$ of air in each line. 


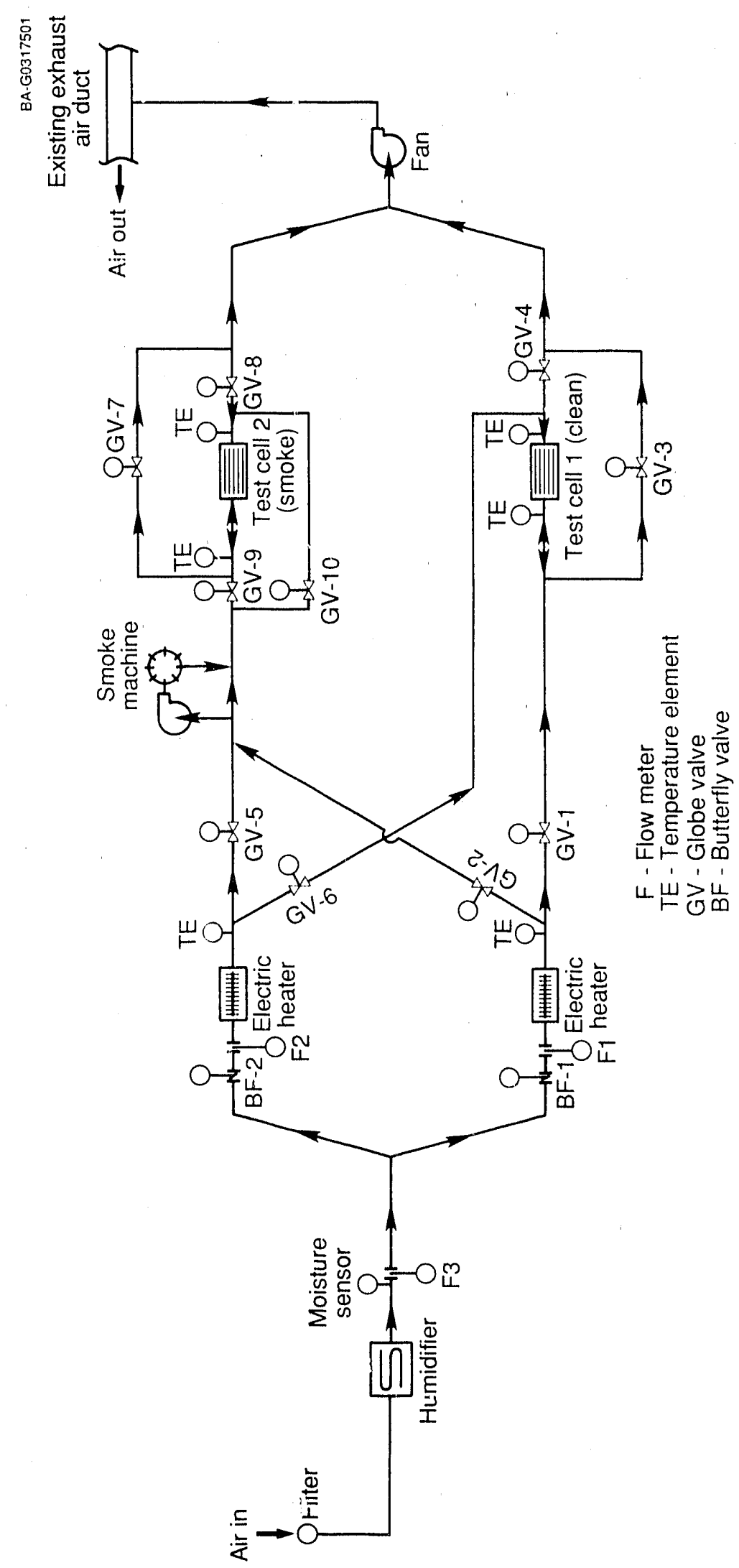

छِ 


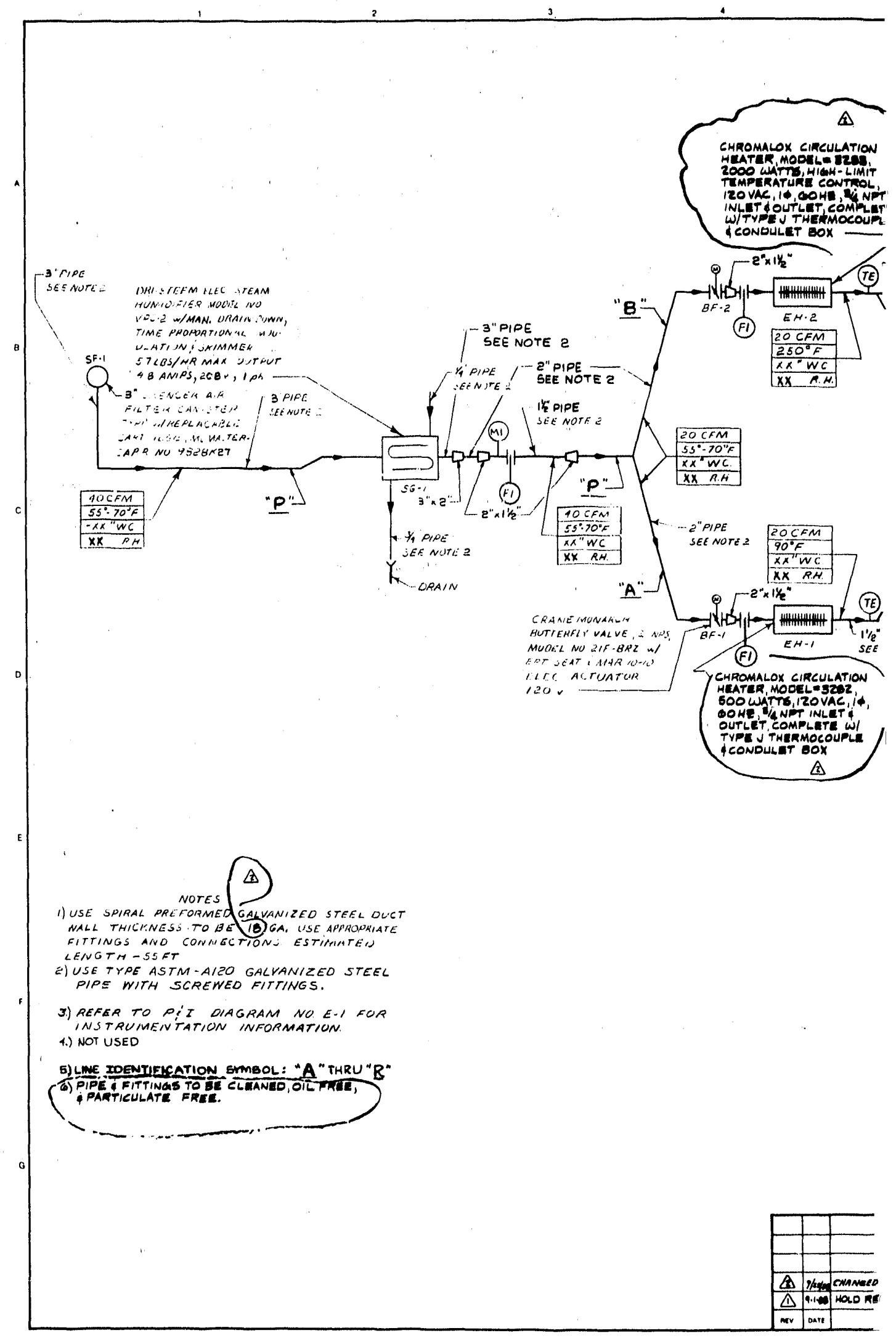




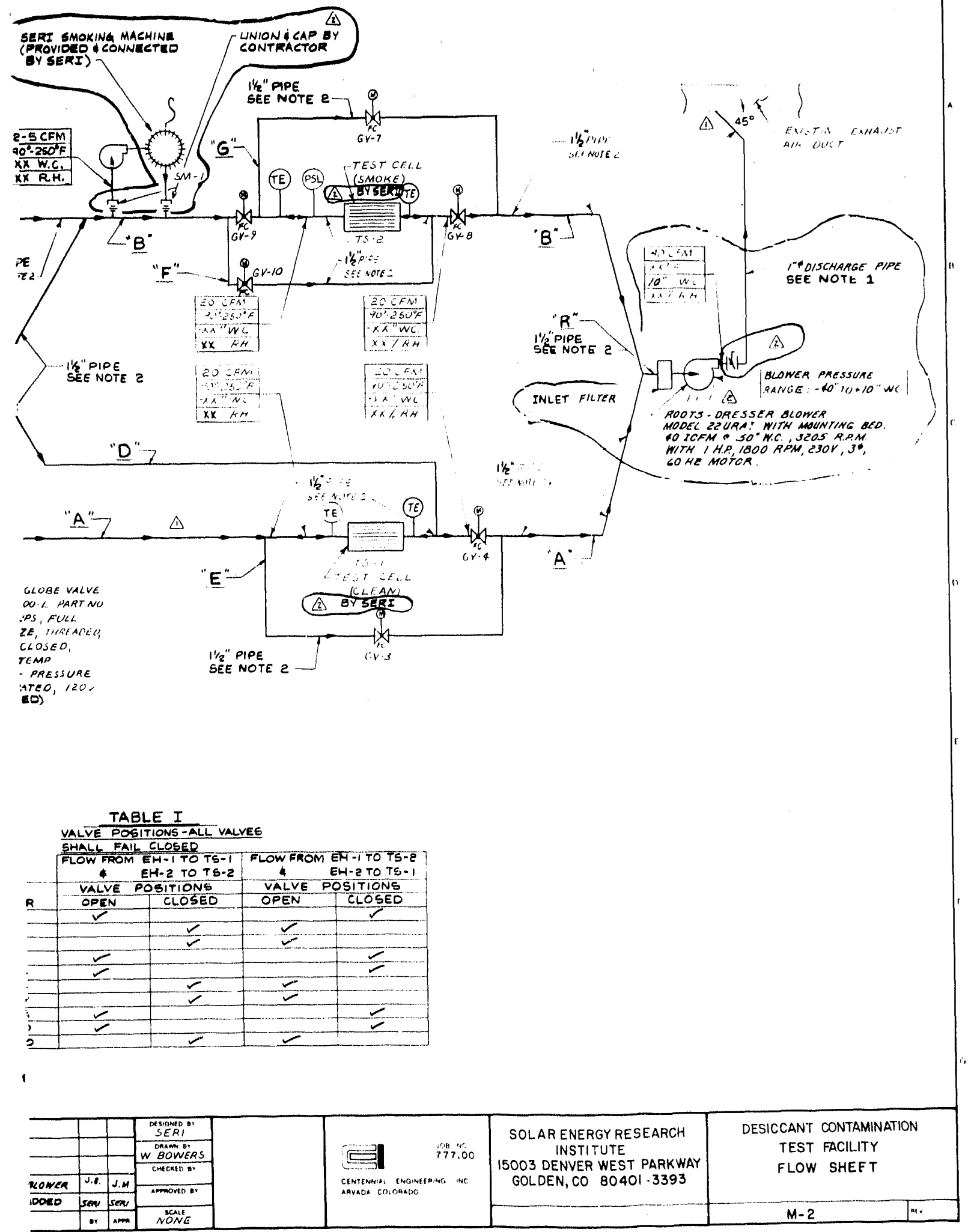

Figure 2-2. Desiccant contamination test facility flow sheet 
Line 1 (the lower line in Figures 2-1 and 2-2) contains a 500-W heater and a clean test cell for base-case experiments. The 500-W heater (Model 3282, manufactured by Chromalox) warms up the air to adsorption temperatures of $30^{\circ} \mathrm{C}$ to $45^{\circ} \mathrm{C}$. Line 2 (the top line in Figures 2-1 and 2-2) contains a $2000-\mathrm{W}$ heater, a smoking machine, and a contaminated test cell for worst-case experiments. The 2000 -W heater (Model 3285, manufactured by Chromalox) heats up the air to a regeneration temperature of $75^{\circ} \mathrm{C}$ to $95^{\circ} \mathrm{C}$. Both heaters are $120 \mathrm{~V}$ and single phase and are supplied with thermostats to control air temperature. The heaters also have high temperature switches which automatically turn off in case of low air velocity through the heaters or a malfunction in the control mechanism.

The heaters are connected to test cells and the smoking machine via 1.5-in. pipe sections and 10 electrically actuated globe valves (series $200-\mathrm{L}$, manufactured by Magnatrol). By opening and closing these globe valves, the air stream going through each test cell is either warm (for adsorption) or hot (for regeneration).

As can be seen from Figure 2-3, when the globe valves 1, 4, 5, 8, and 9 are open and the remaining valves are closed, air heated by the $2000-\mathrm{W}$ heater (to regeneration temperatures) passes through the contaminated test cell. In this configuration, warm air produced by the $500-\mathrm{W}$ heater passes through the clean test cell for moisture adsorption by the desiccant samples. In another configuration (Figure 2-4), the globe valves $1,4,5,8$, and 9 are closed and the remaining valves are open. In this configuration, warm air from the 500-W heater is directed toward thi contaminated test cell for the adsorption process, and hot air from the 2000-W heater passes through the clean test cell for regeneration. In both figures, the flow paths are shown with s,olid lines and the closed pipes are shown with dashed lines. The valves are turned on or off with a repeat cycle timer (Series DA 100 Miniflex, manufactured by Eagle Signal Industrial Controls) to simulate the cycle time between adsorption and regeneration for dehumidificrs.

It is important to note that the regeneration and adsorption air streams pass through the desiccant samples in opposite (i.e., countercurrent) directions, a condition similar to that in operation of fixed and rotary dehumidifiers. A detailed analysis (Pesaran 1988) showed that a parallel-flow configuration results in a desiccant temperature and moisture content that are not typical of those encountered in the operation of typical dehumidifiers. The facility was designed to simulate the countercurrent conditions in spite of its added conplexity.

Air streams leaving the test cells merge together into one stream which passes through a filter, for removing cigarette particles, before entering a blower (Model 22 URAI, manufactured by Roots-Dresser). The blower ( $230 \mathrm{~V}, 3$ phase and $1 \mathrm{hp}$ ) draws the ambient air through the components and then discharges it to the existing building exhaust air duct. The air from the facility is finally discharged to the outside of the building via the building ventilation system.

Although use of three- or four-way valves would have reduced the iumber of pipe sections and crossovers, we selected two-way valves because they are more reliable, available, and inexpensive. These valves are normaily closed. In case of power failure, all the valves will be automatically closed to stop smoke from reaching the clean test cell.

Figure 2-5 shows the general arrangement, including the plan and elevation of the test facility. The facility is located near the west wall of the desiccant cooling laboratory at the SERI Field Test Laboratory Building (FTLB), as shown in Figure 2-6. A photograph of the facility is shown in Figure 2-7. 


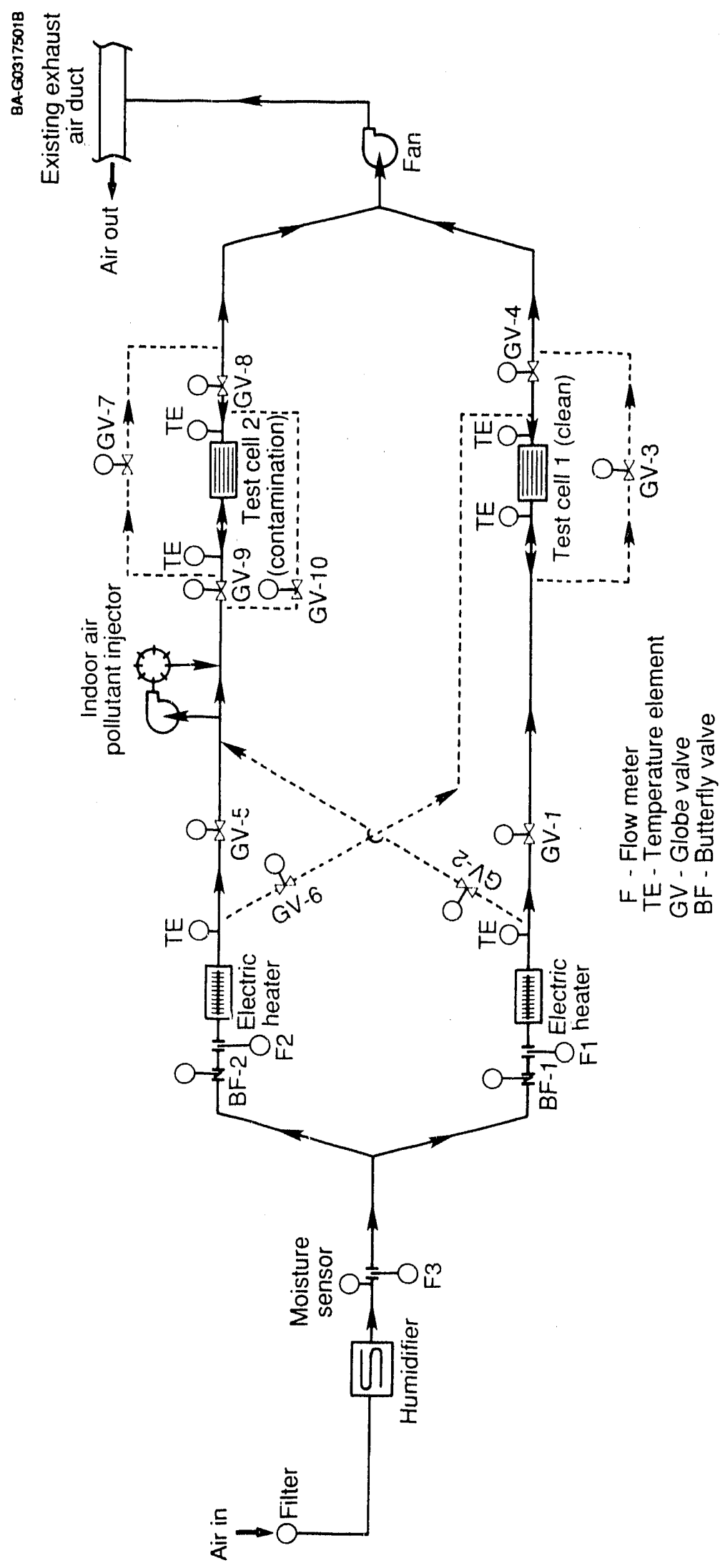




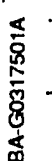

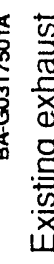

市

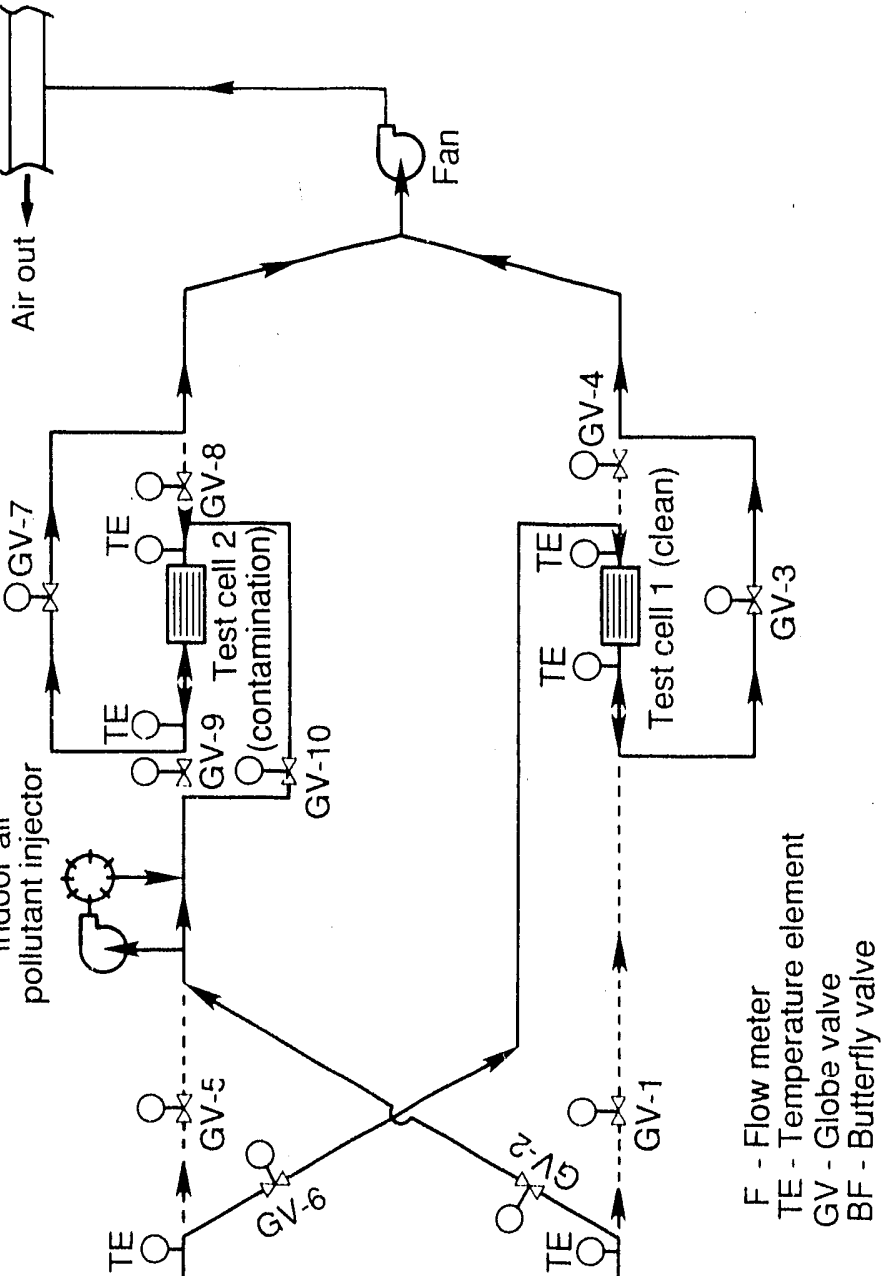

$\frac{5}{8}$

음

$\overline{8}$

Ð

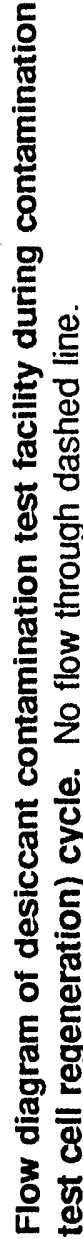

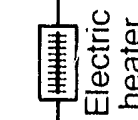

園害离

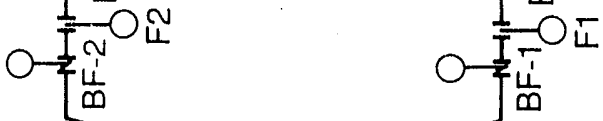

迹
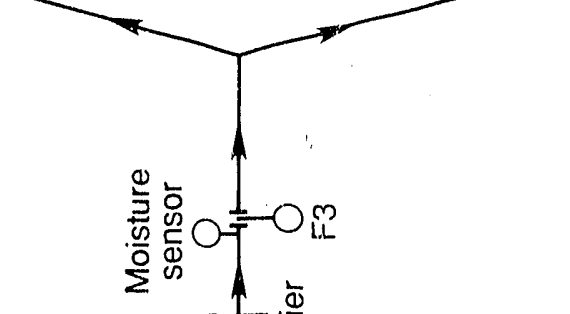

Uी

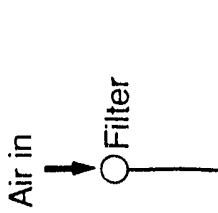

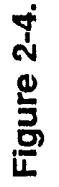




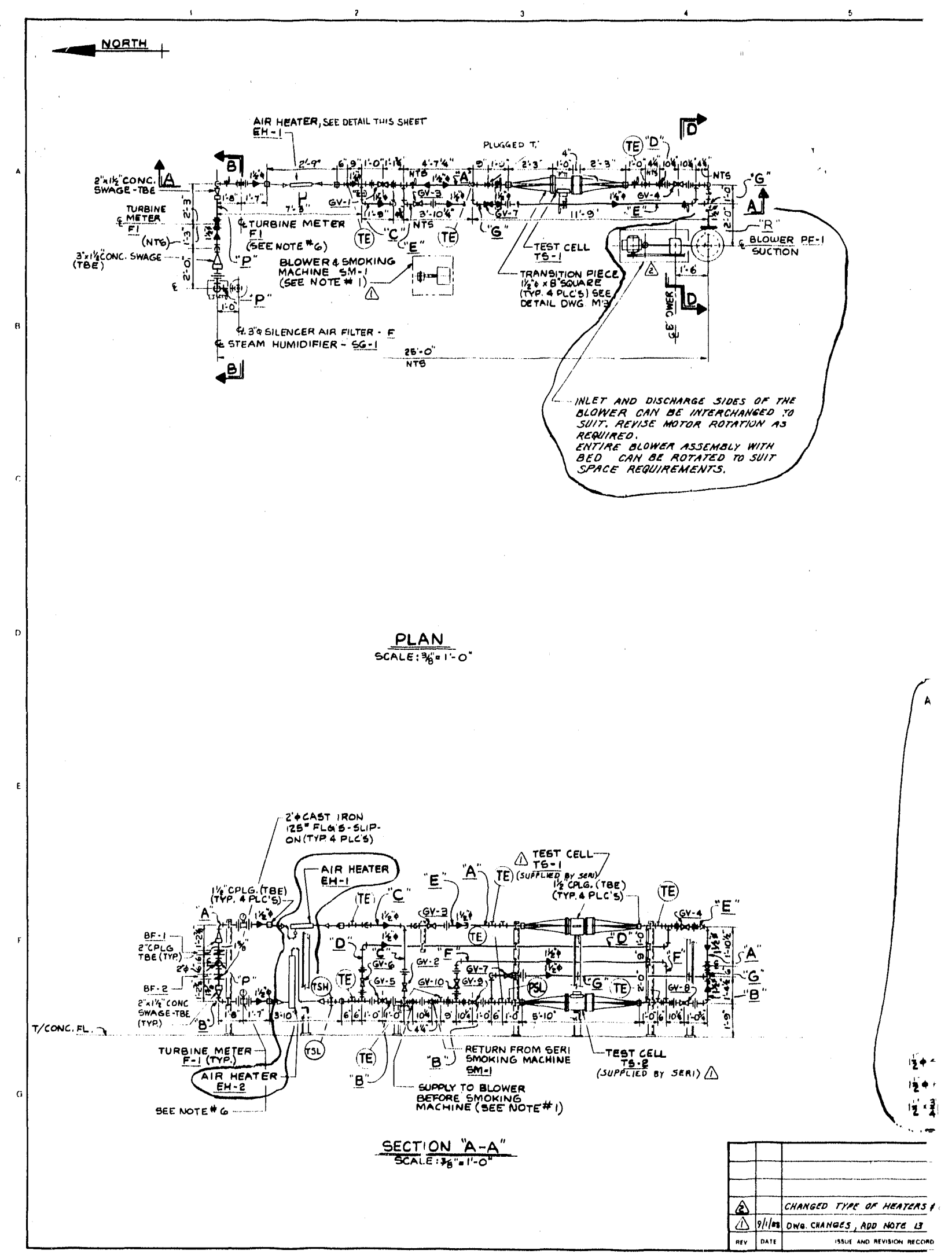


TP-3457

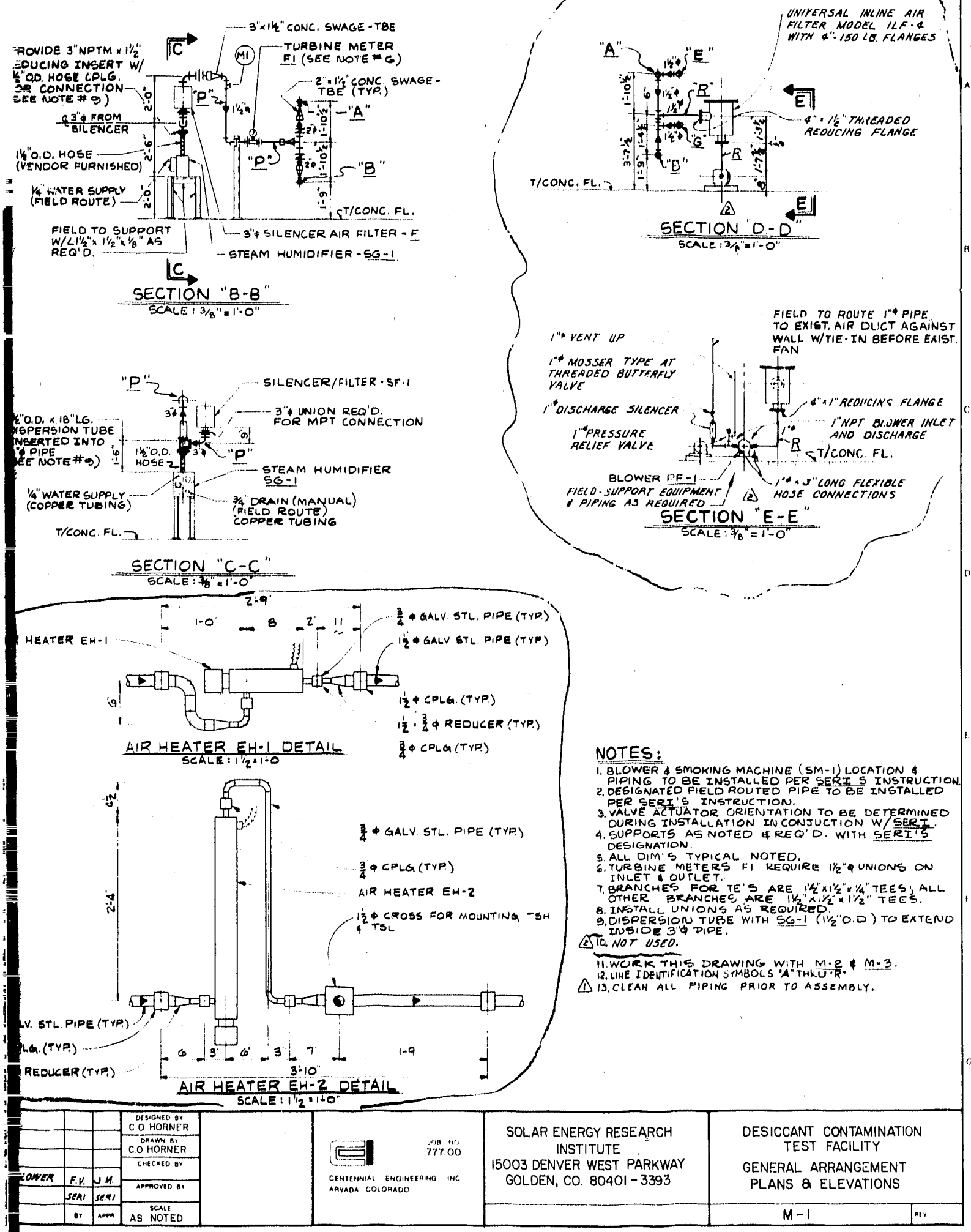

Figure 2-5. Desiccant contamination test facility general arrangement-plans and elevations 


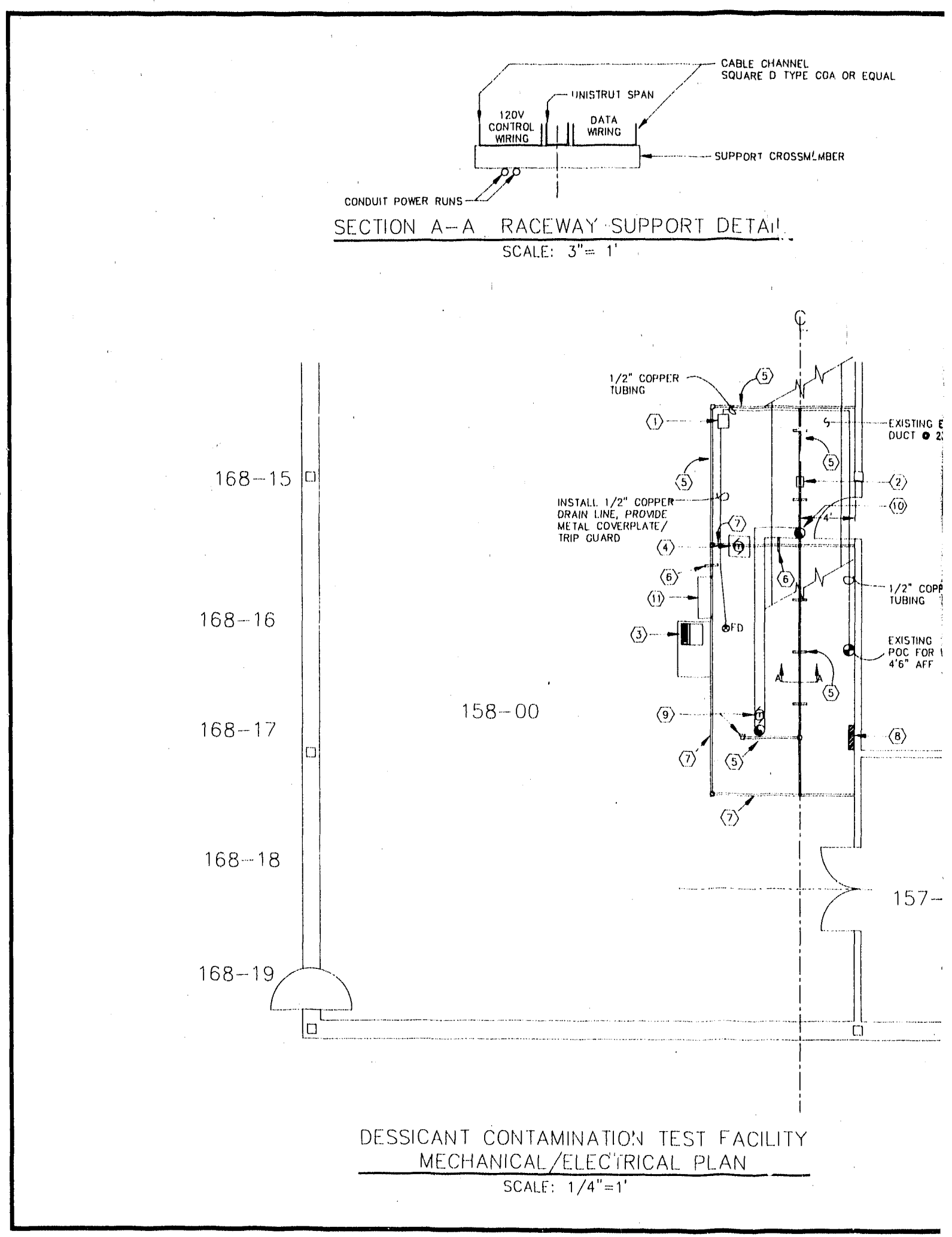




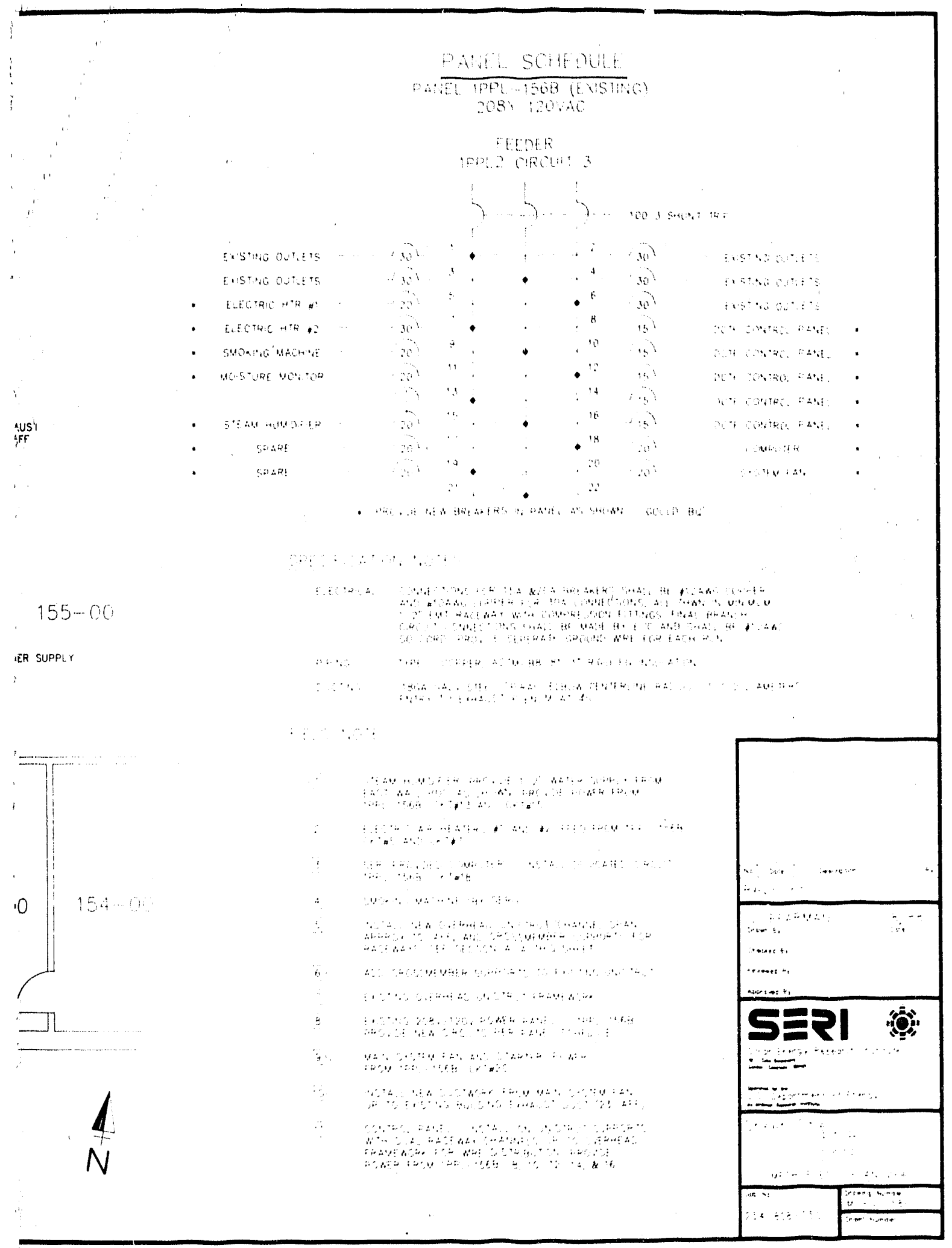

Figure 2-6. Desiccant contamination test facility layout in desiccant cooling laboratory 


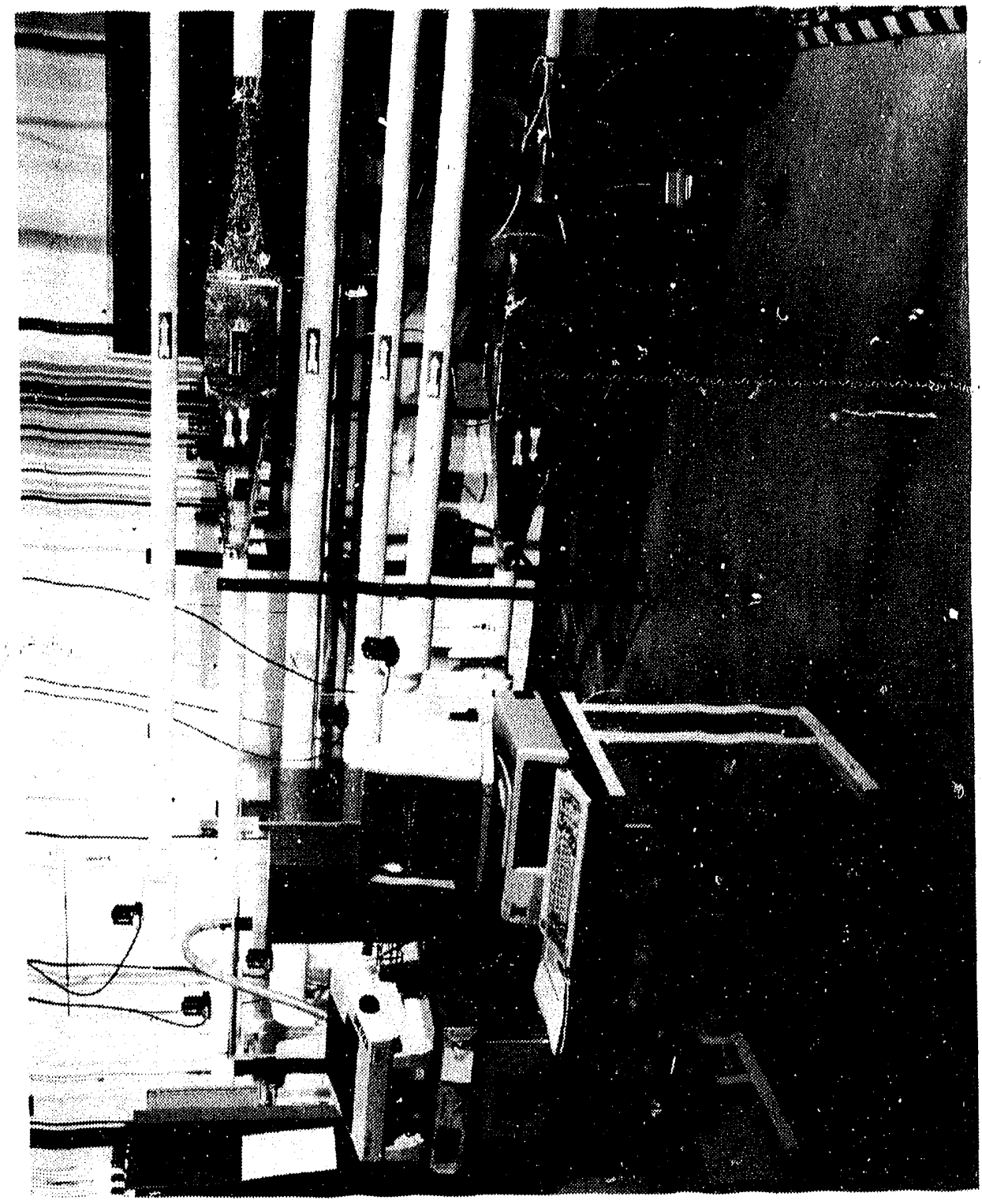

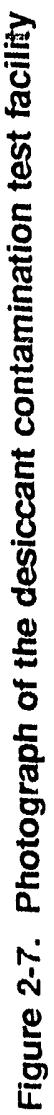




\subsection{Description of Test Cells}

Each test cell was designec to hold 100 sample test tubes containing desiccant material. Each cell contains a test cell holder with 100 cylindrical sleeves attached to it, $a$ test cell box enclosing the holder, and two reducers for connecting the test cell to the other components of the facility (Figure 2-8).

The sample test tubes are made of brass and have the following dimensions:

$\begin{array}{ll}\text { Outer diameter: } & 11 / 32 \mathrm{in} . \\ \text { Wall thickness: } & 0.014 \mathrm{in} . \\ \text { Length: } & 3.0 \mathrm{in} .\end{array}$

Each test tube can hold either desiccant particles (with screens on both ends for holding them in place) or a desiccant matrix (with walls coated or impregnated with desiccant materials). Figure 2-9 shows a sample test tube with desiccant silica gel particles and two screens.

The sample test tubes can be inserted into the sleeves of the test cell holder (see detail A in Figure 2-8). About $1 / 4$ in. of each sample tube will be wrapped with Teflon tape so the tube does not go into the sleeve completely and can easily be removed. The brass sleeves have an outer diameter of $3 / 8$ in., wall thickness of 0.014 in., and are 3 in. long. The test cell holder is mounted at the end of the test cell box with 12 bolts. The test cell box, which is made of $1 / 8$-in. stainless steel sheets, has a cross section of 8 by 8 in. and is $11-5 / 8$ in. long. The box has a removable door for easy access to the sample test tubes in the sleeves of the test cell holder. The walls of the box also serve as mounting bases for measuring sensors. A section at the other end of the test cell holder which is 3-7/8 in. long and 8 by $8 \mathrm{in}$. in cross section is used for mounting measuring sensors.

The air from the 1.5-in. pipe enters a reducer that smoothly goes from a round cross section to a square cross section of the test cell box. The reducer is designed for smooth and uniform transition of the air flow. The air passes through the test tubes containing desiccants and enters another reducer for smooth and uniform transition of air from the square cross section of the test cell to the round aross section of the piping. Both reducers are about 25 in. long, having a 1.5 -in. round cross section on ore end and an 8 -by -8 in. square cross section at the other end. The reducing angle is 7.5 degrees. A pilotc graph of the test cell is shown in Figure 2-10. The opened test cell with the 100 sleeves showing is tepicted in Figure 2-11.

\subsection{Descriptlon of Smoking Machine}

To contaminate desiccant materials with fresh cigarette smoke for the worst-case experiments, a smoking machine was needed. We contemplated various ideas, from in-house design and fabrication to purchasing commercial smoking machines. We contacted Phillip Morris of Richmond, Virginia, a major tobacco company, to assist us. They provided useful information and the names of two major manufacturers of smoking machines: Filtrona of Englant and Borgwaldt of West Germany.

We contacted the U.S. representatives of these two companies and obtained further information about their products. Neither had machines to meet our unique applications. We also found that in-house fabrication of a smoking machine required a basic knowledge about cigarette handling unavailable at SERI. We then specified our unique needs to the U.S. representatives of two machine manufacturers. Fidus Instrument Corporation, the U.S. representative of Filtrona ${ }_{4}$ accepted the task of assembling a smoking machine to our specifications. 


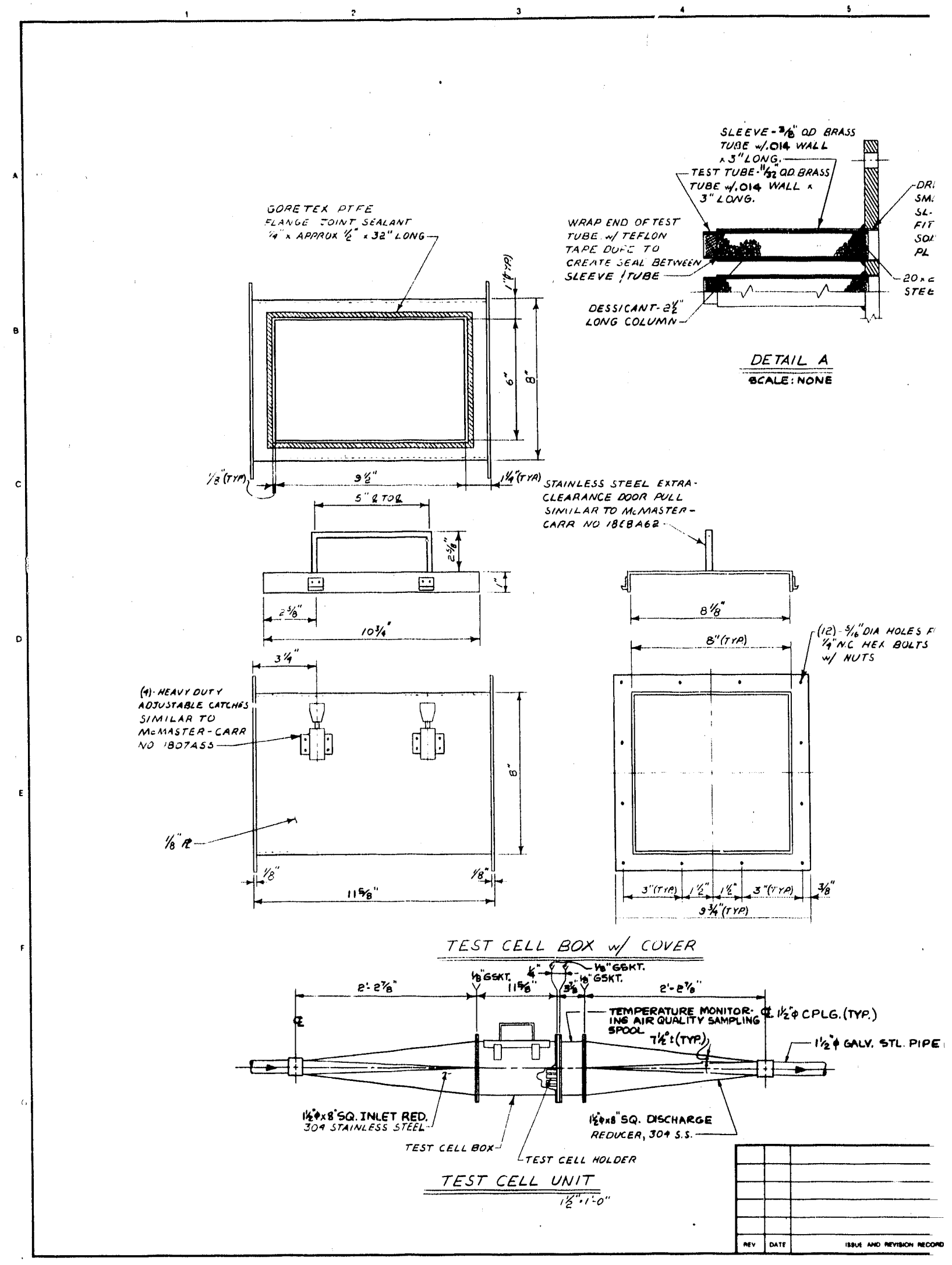


L HOLE OOOS"DIA

VER THAN O.D. OF

VE. HEAT SHRINK

LEEVES TEGVES TO

MESH STAINLESS SCREEN PLUG. (TYP) $\vdots$

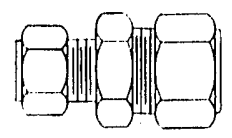

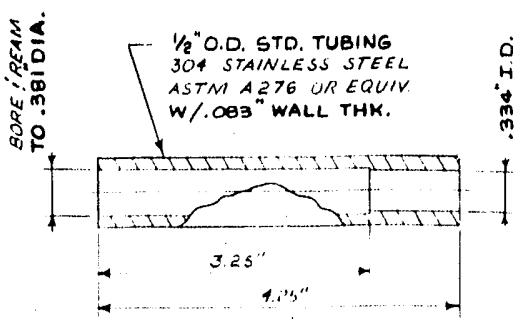

AIR PURGE TEST LELL HOLDER

$\frac{\text { AIR PURGE TEST LELL HOL OLR }}{\text { SCALE: NONE }}$
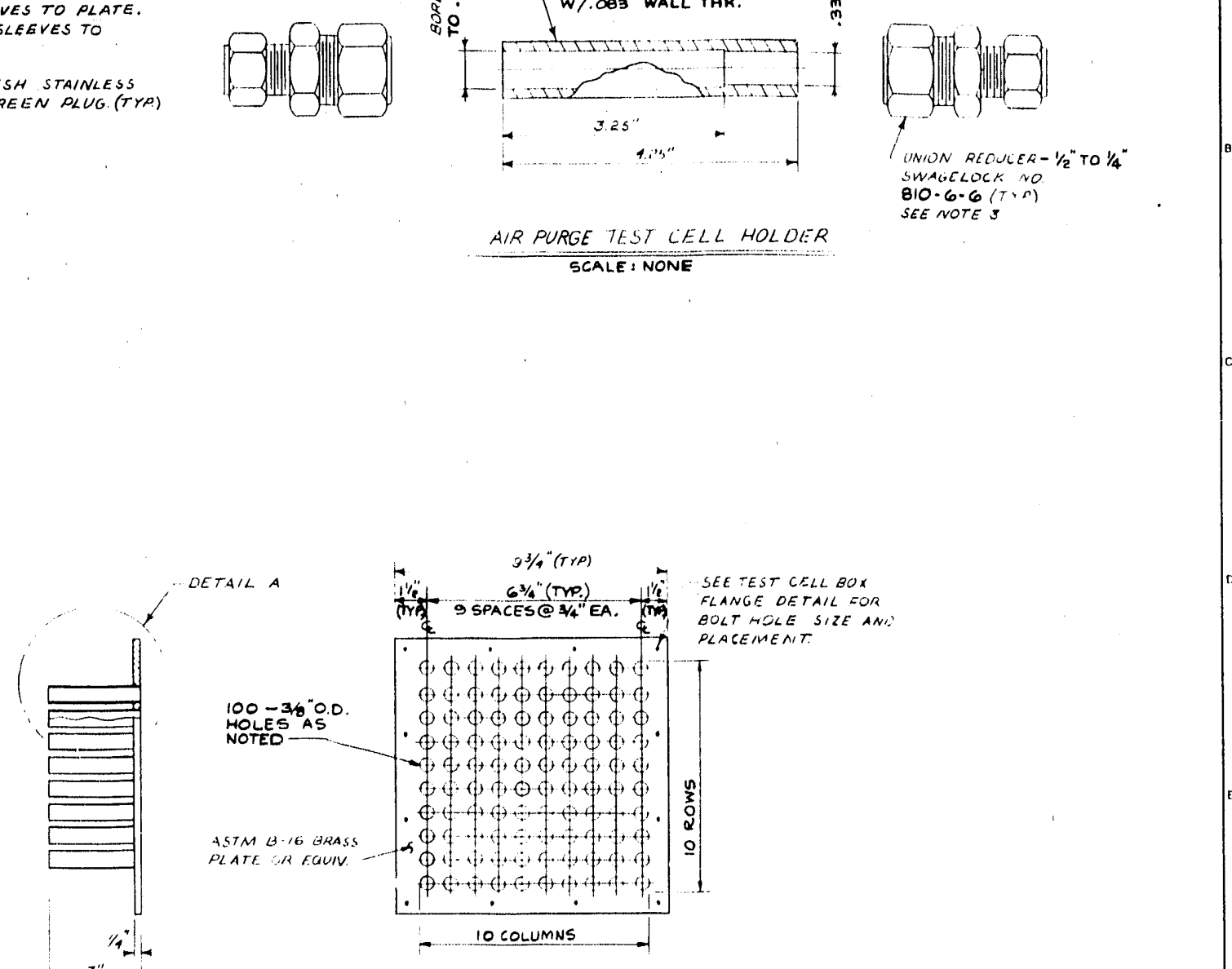

$810 \cdot 6-6(T, A)$
TEST GELL HOLDER
SCALE : NONE

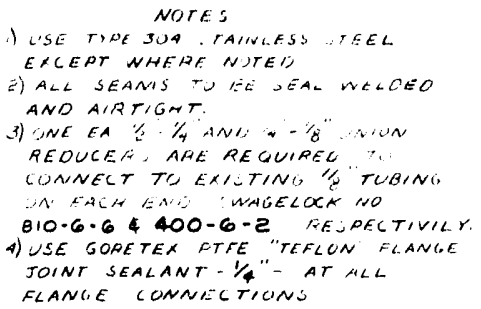

IYP.)

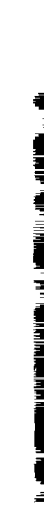

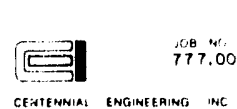

CEATEnNiai Enginetaing INC
SOLAR ENERGY RESEARCH INSTITUTE 15003 DENVER WEST PARKWAY GOLDEN, CO. $80401-3393$
DESICCANT CONTAMINATION

TEST FACILITY

DESSICANT TEST CEL L 


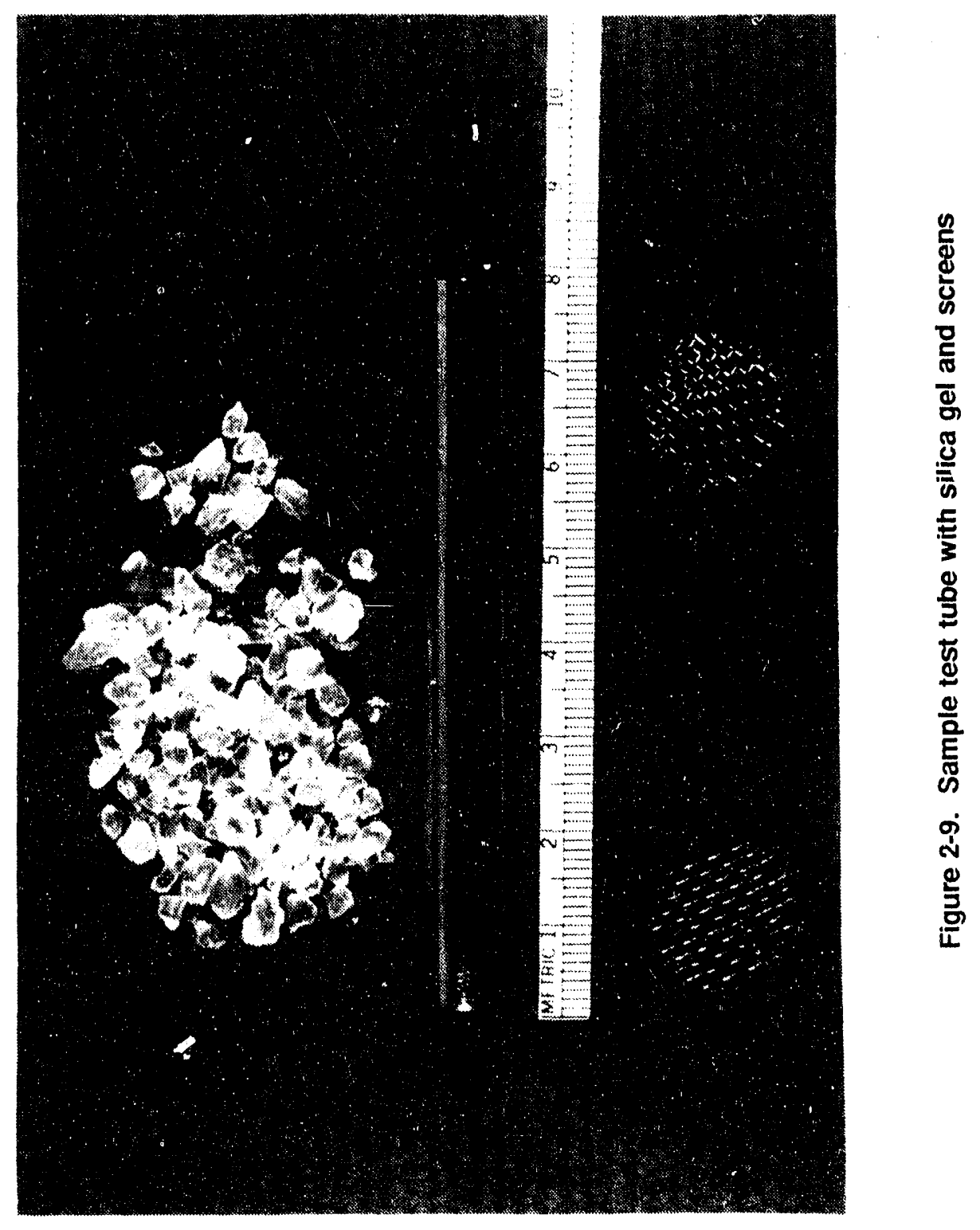




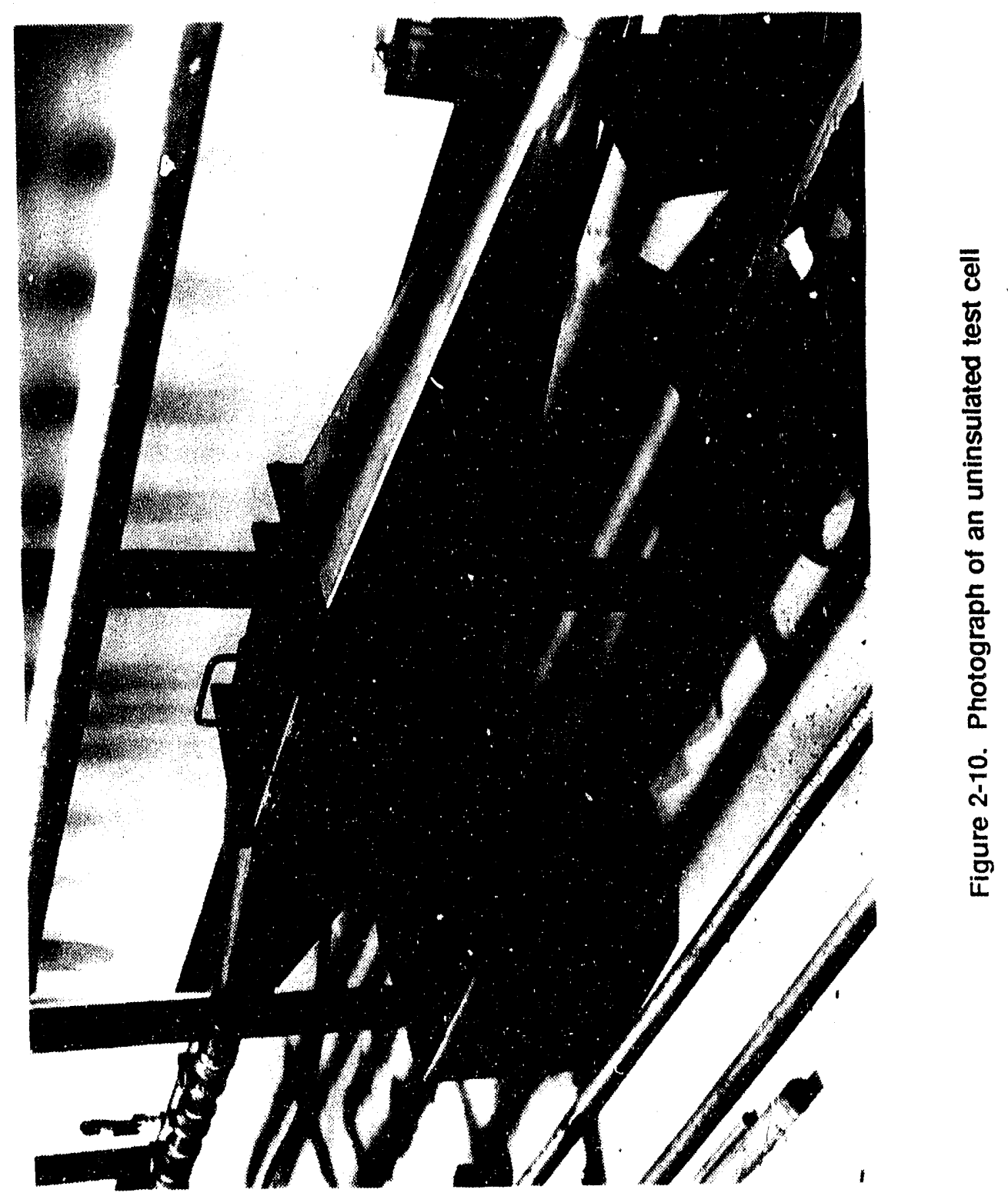




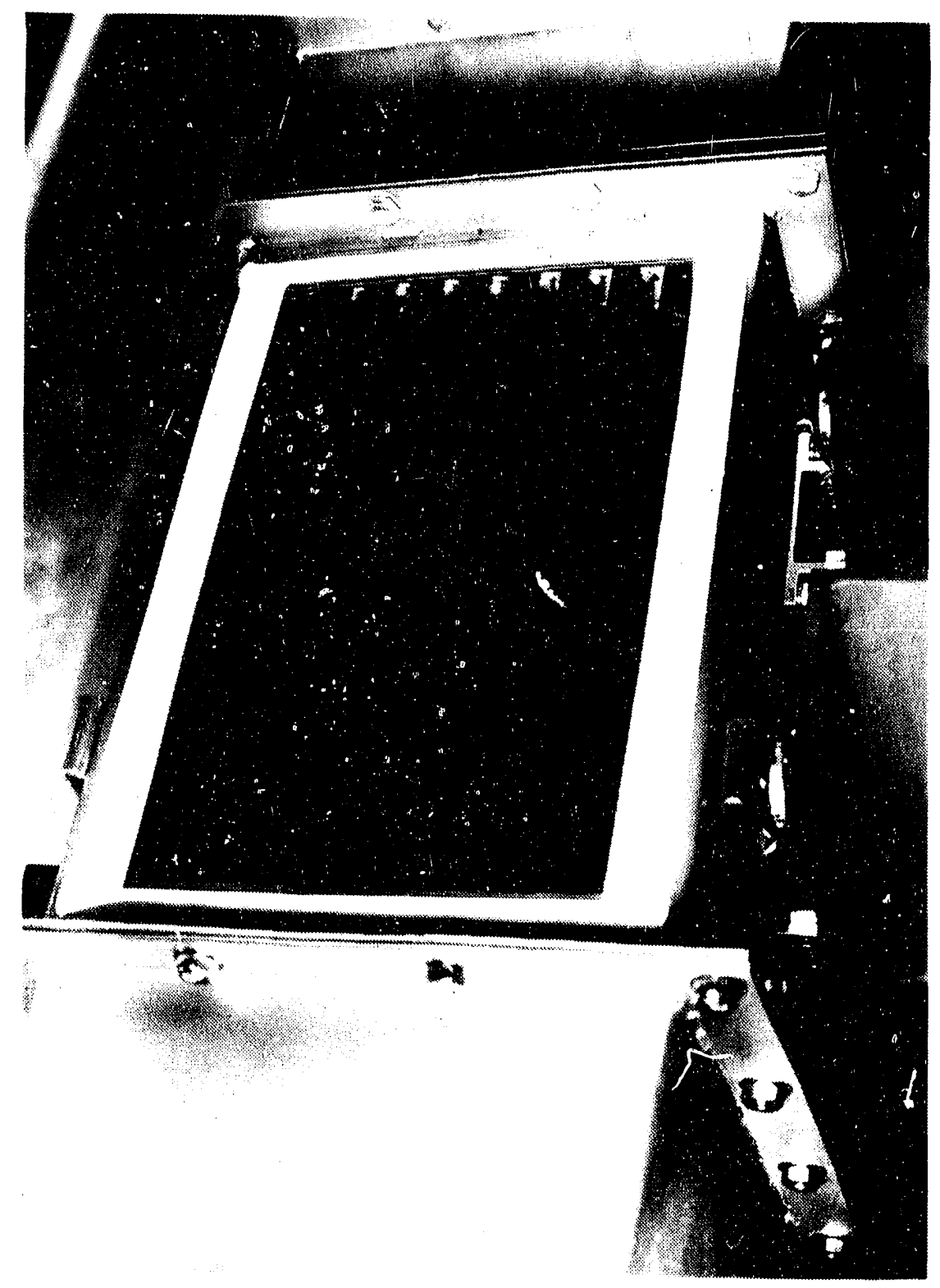

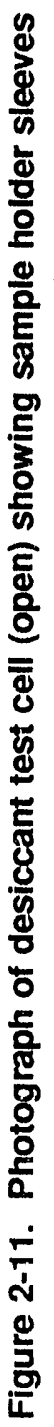


We identified the following specifications for the smoking machine:

- The machine must burn an equivalent of six cigarettes per hour continuously.

- The machine must smoke for at least 24 hours a day, requiring a minimum capacity of 144 cigarettes.

- The machine should generate smoke for three days without reloading, requiring a capacity of 432 cigarettes.

- The machine must be in an enclosure that is air tight except for about $0.3 \mathrm{cfm}$ air drawn from ambient through a 1-in. hole in the enclosure.

- The generated smoke must be supplied to the contaminated test cell via a 1.5 -in. pipe.

- The cigarette or tobacco ashes must be prevented from going into the main air stream in the facility. Ashes should be easily collected and removed from the machine for proper disposal.

- The overall dimensions of the machine should not exceed $4 \mathrm{ft} \times 4 \mathrm{ft} \times 5 \mathrm{ft}$.

Fidus Instrument Corporation was contracted to build the smoking a nachine and started fabrication in December 1988. The machine was installed at SERI in March 1989.

According to Fidus, the smoking machine can burn 530 cigarettes consecutively (1 every 10 minutes) without reloading and with no operating or maintenance requirements after start-up. The machine consists primarily of the following parts:

- Plexiglass-fronted, air-tight cabinet with fixtures for venting to the test cell of the desiccant contamination test facility

- Frame for smoking machine

- Hopper to hold 530 cigarettes, with an approximate run time of 3.5 days

- Smoking drum to hold cigarettes in front of lighter

- Hopper drum to transfer cigarettes from hopper to the smoking drum

- Electric cigarette lighter

- transformer

- timing circuits with photoelectric sensors.

The machine operates with $120-\mathrm{V}$ single-phase power. During operation, the hopper drum transfers one cigarette thit the hopper to the smoking drum. The smoking drum holds the cigarette toward the lighter to be lit. The cigarette is burned horizontally. Then the smoking drum rotates, drops the butt, and grabs another cigarette from the hopper drum. The process repeats every 20 minutes. Figure 2-12 shows the smoking machine. 


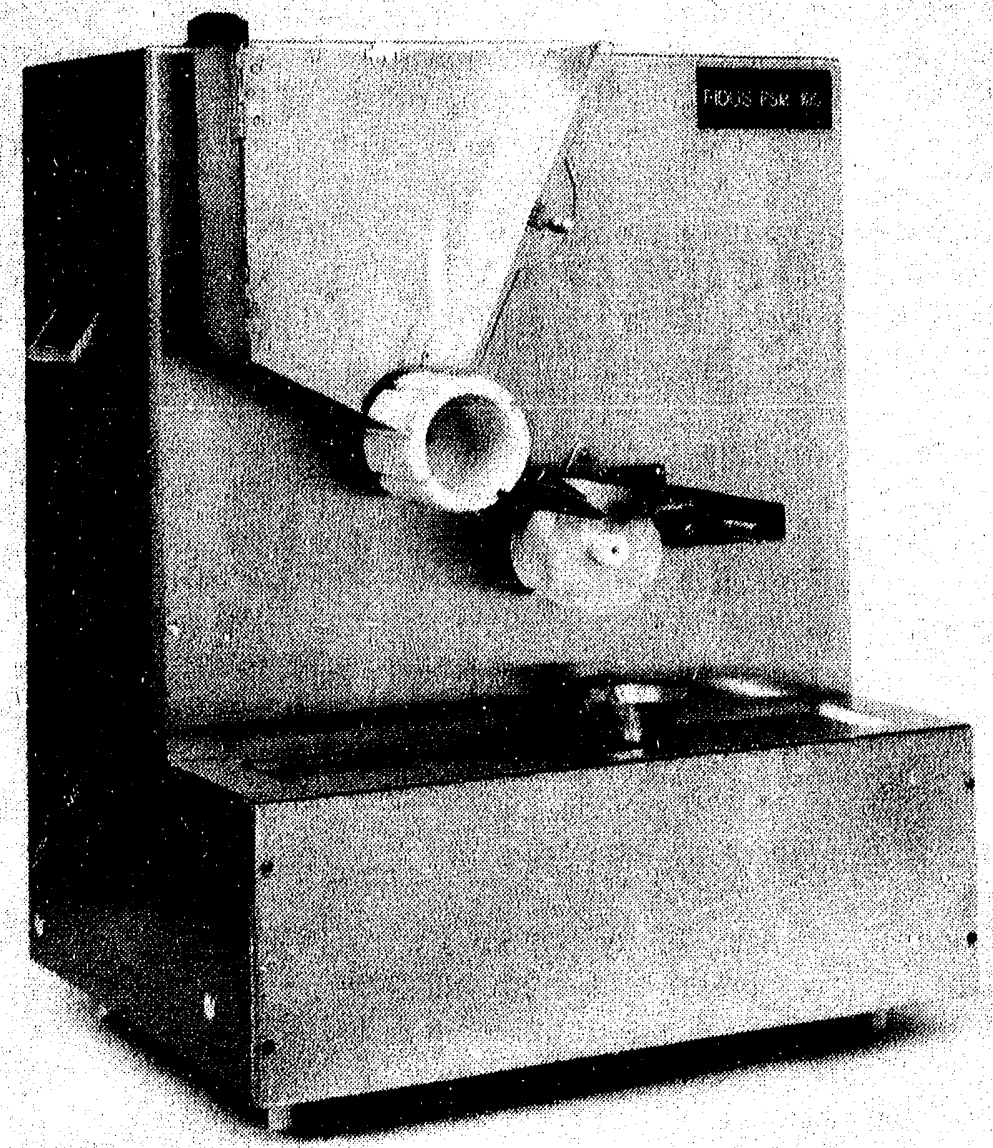

Figure 2-12. Photograph of smoking machine 


\subsection{Instrumentation and Control}

The experimental parameters of the desiccant contamination test facility are monitored, controlled, and recorded by various software and hardware. The air temperatures, air humidity, and air flow rates are controlled by stand-alone control hardware like thermostats and humidistats. Figure 2-13, the process and instrumentation diagram (P \& ID) flow sheet of the facility, shows the control strategies and the instrumentation.

The humidifier is controlled with a humidistat. The air humidity is measured with a dewpoint hygrometer (Model 1100DP, manufactured by General Eastern) and is fed back to the humidistat and compared with the set-point dewpoint. The humidistat, in turn, will energize or de-energize the electric humidifier to obtain the desired set-point temperature.

The heaters are controlled with thermostats. Type $\mathrm{T}$ thermocouple probes are used to sense the air temperature in the two main lines of the facility and send signals to the thermostat. The air temperature is compared with the set-point temperature, and necessary action is relayed to the heaters to obtain the desirea set-point.

The flow rate in each line is controlled with a flowmeter, a flow controller, a position controller, and a butterfly valve. The flowmeter measures the flow rate and a signal to the flow controller, which compares this flow rate with the set-point flow rate. Depending on the offset, a signal is sent to the position controller, which opens or closes the butterfly valve to obtain the desired set-point flow rate.

The cycling time between regeneration and adsorption in each test cell is controlled by simultaneously opening (or closing) one set of valves $(1,4,5,8$, and 9) and closing (or opening) another set of valves $(2,3,6,7$, and 10$)$ by a repeat cycle timer (Series DA 100 Miniflex, manufactured by Eagle Signal Industrial Controls).

The electrical design and wiring diagrams were prepared by Behrent Engineering Company, a subcontractor of Centennial. The electrical diagrams and wiring for start-up, control, and instrumentation of the facility are given in Appendix B. An annunciator/control panel with on/off lights to show the status of various components of the facility has been designed and fabricated. For example, the panel can show if heaters, the humidifier, the smoking machine, and the blower are operating or have failed. During continuous and unattended operation of the test facility, this panel is very useful for indicating which components are working properly. Figure B-4 in Appendix B shows the layout of the pancl.

In the event of shutdown of the air blower (accidentally or purposefully), other components of the facility are automatically turned off to prevent any damage to the test facility.

The data-acquisition system for the test facility combines software and hardware to handle the collection and analysis of data. The air flow rates are measured with three 1.5-in. turbine flowmeters (Model 6822, manufactured by Hydril) in each branch and in the main flow into the facility. These units provide a 4-20 ma signal proportional to the air flow rate. Humidity measurements are taken with a General Eastern Model 1100DP dewpoint hygrometer with 1111D chilled-mirror sensors. Temperatures along the flowstreams are measured with six type $T$ thermocouple probes (manufactured by Thermetrics). 'A cross section of the air temperatures in and out of each test section is measured with four type T thermocouples, using an array similar to that used at the SERI heat- and mass-transfer test facility. Also used are two MKS Baratron 221A differential pressure sensors to monitor the pressure drop across each test cell. The total pressure in each test cell is measured with a MKS 220A pressure transducer. The location of scnsors is shown in Figure 2-14. 


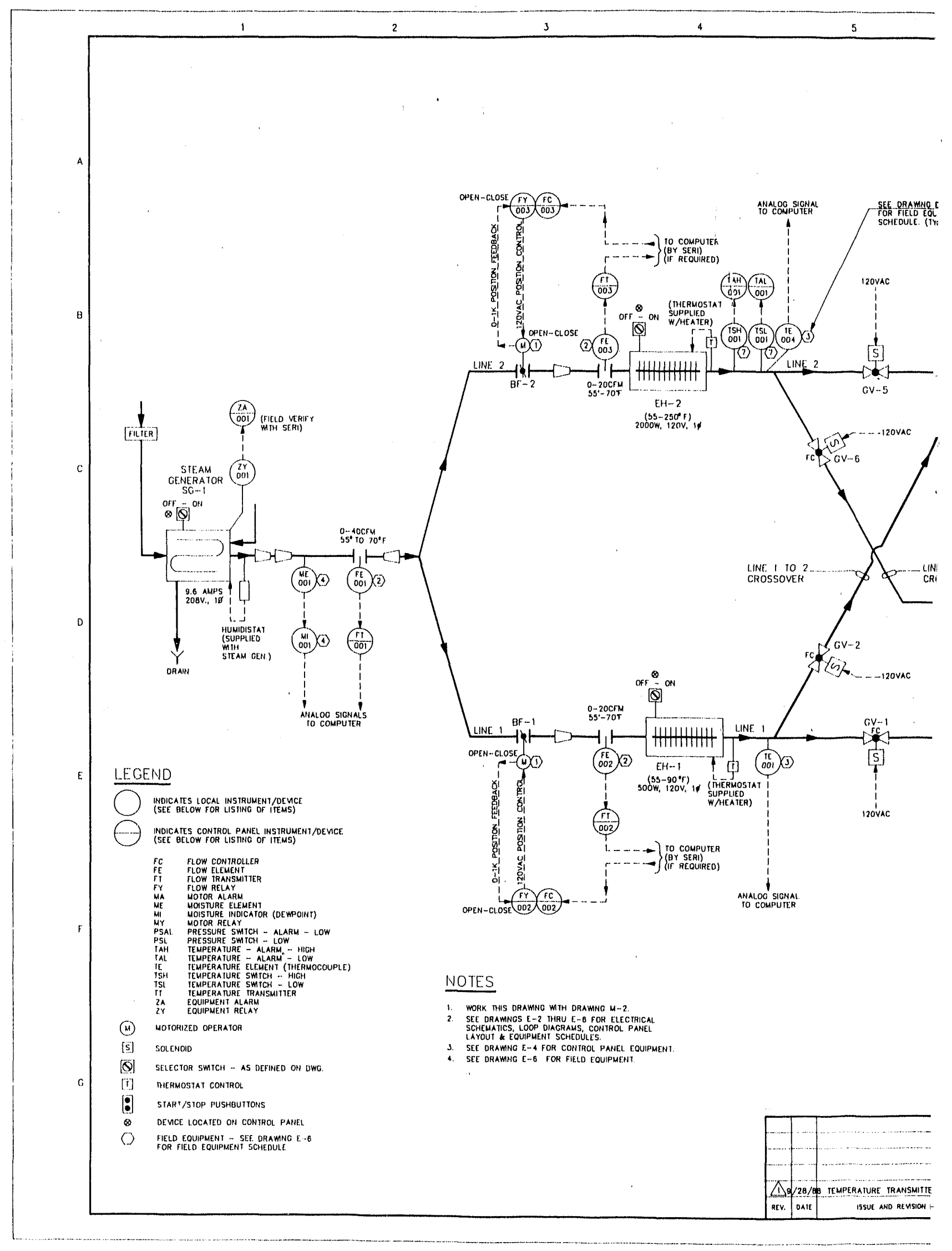



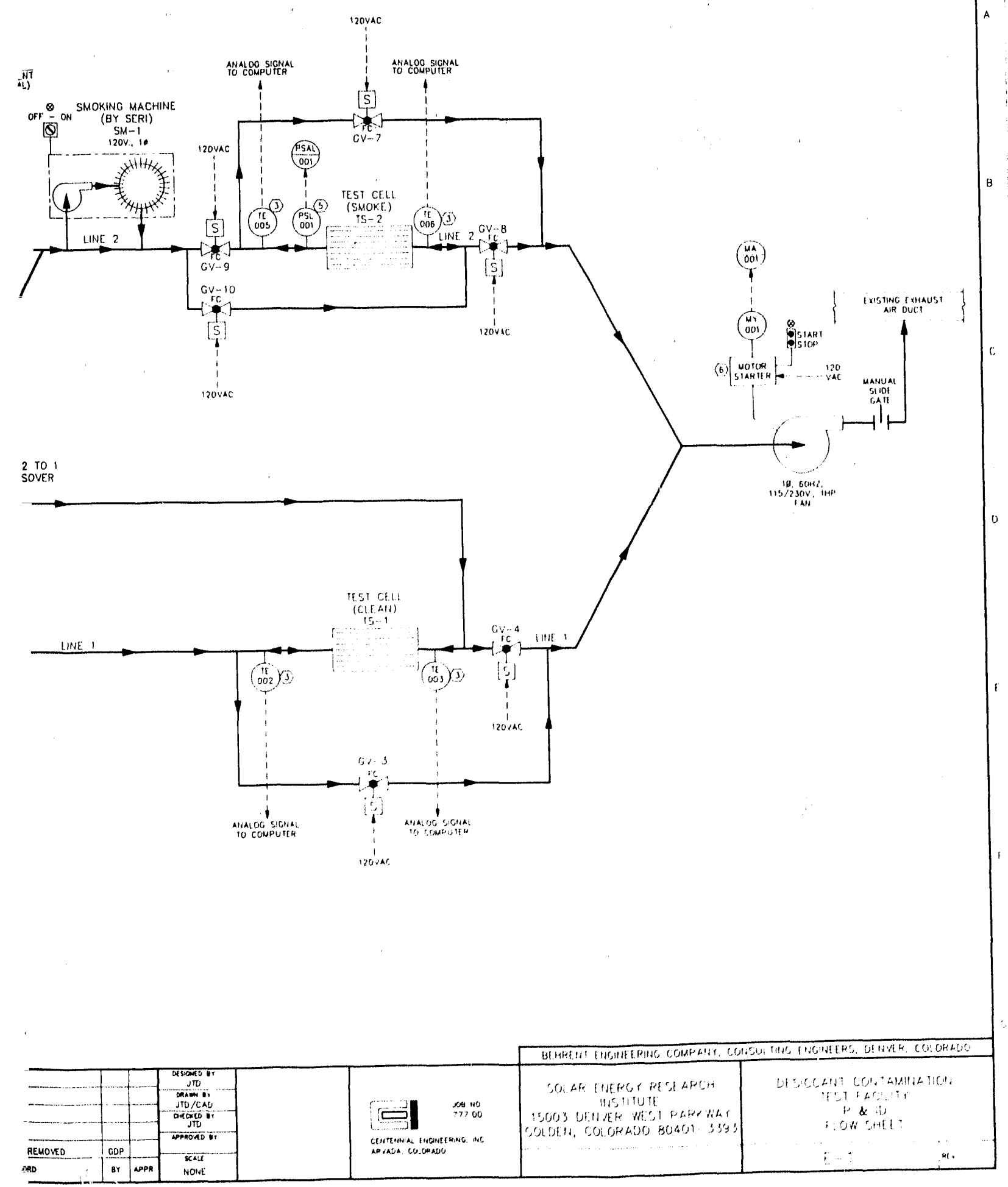

Figure 2-13. Desiccant contamination test facility P\&ID flow sheet showing control strategies and instrumentation 


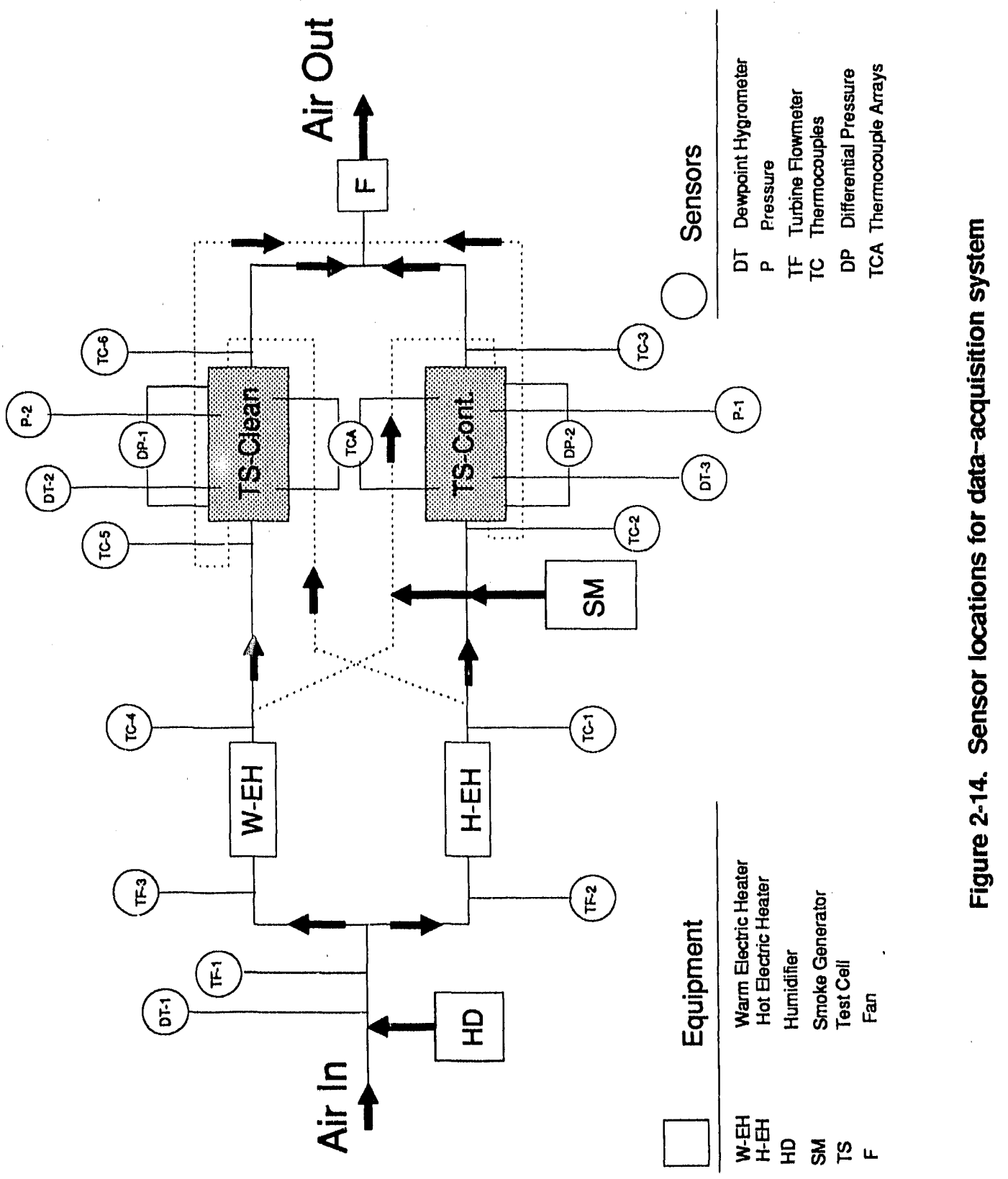


The hardware to collect, display, and analyze the data is similar to that used in other test equipment at the Desiccant Cooling Laboratory. The Hewlett Packard 3497A scanner, with a digital voltmeter (DVM) option, is one of the most reliable and accurate scanner/DVMs. The HP3497A takes the analog signals from the sensors and transducers and measures the voltage or resistance signals. The measured signals are then passed through an IEEE-488 bus to an IBM PC equipped with a National Instruments GPIB PC-2 interface board. The IBM PC is equipped with high-resolution VGA graphics and a graphics printer. An overview of the data-acquisition system is presented in Figure 2-15. A photograph of the data-acquisition hardware is shown in Figure 2-16.

The software chosen for data acquisition is LabTech Notebook from Laboratory Technologics. It is capable of graphically displaying the data in real time and is easily changed as the requirements of the test change. LabTech Notebook is a generic data-acquisition program that can be adapted to most test situations. Also used is Laboratory Technologies' Real Time Access, which allows for data acquisition in the background and access to the data in the foreground for analysis. This allows us to run an independent analysis program (1-2-3 or a Pascal program) to analyze the data while they are being collected. The Real Time Access Option allows us to display customized presentations such as multiple windo'ss while data are being collected.

In addition to the above measurements, the concentration of certain pollutants will be measured with a portable gas chromatograph (Scentograph Model, manufactured by Sentex Sensing Technology, Inc.). The chromatograph, which has an Argon Ionization/Electron Capture (AI/EC) Detector, belongs to the SERI Building Research Branch. It will be used once or twice a week to monitor the major constituents of cigarette smoke such as acetaldehyde, methylchloride, acetone, ammonia, formaldehyde, and hydrogen sulfide. By replacing the $\mathrm{Al} / \mathrm{EC}$ detector with a thermal conductivity detector and adding an appropriate packed column, the chromatograph can measure the concentration of carbon monoxide and carbon dioxidc. Infrared or chemiluminescent analyzers are needed to measure the concentrations of nitrogen oxide and nitrogen dioxide. 


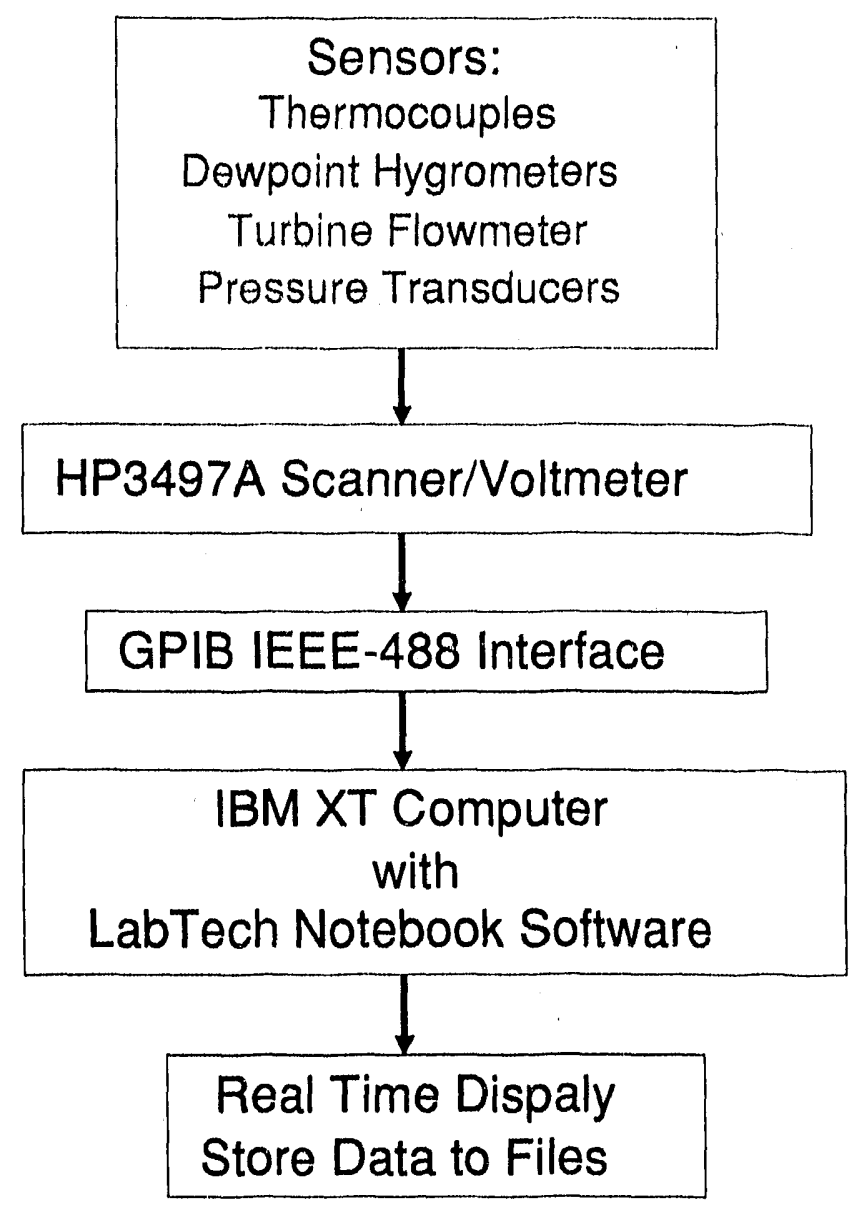

Figure 2-15. Data-acquisition system flow chart 

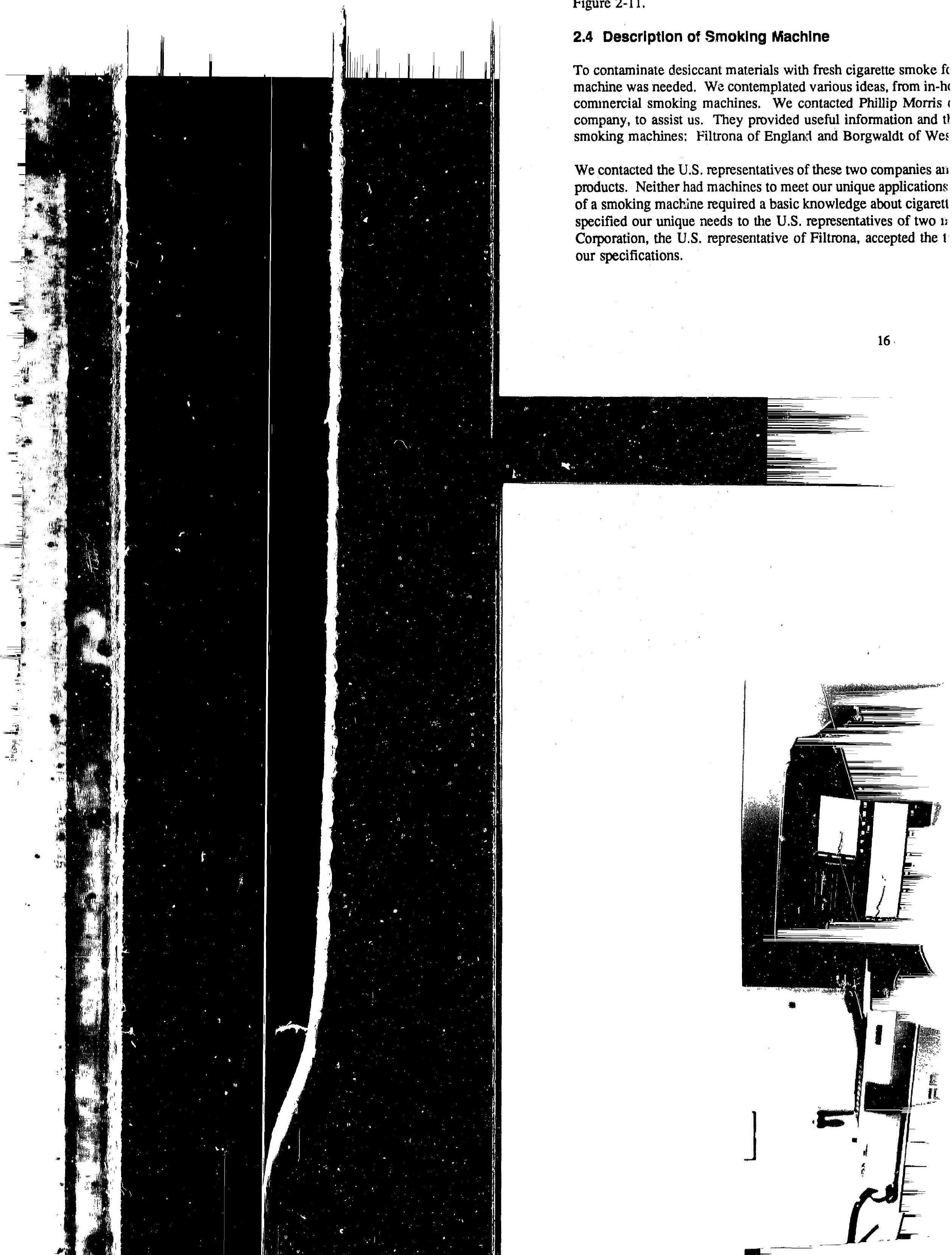


\subsection{EXPERIMENTAL PROCEDURE}

The function of the desiccant contamination test facility is to contaminate desiccant samples under conditions found in the operation of solar desiccant cooling dehumidifiers. Experiments or analysis to measure the degree and cause of degradation will be done elsewhere. This section covers the desiccant material selected for investigation, the operation of the facility, and the measurements needed to characterize degradation.

\subsection{Deslccant Materlals for Testing}

\subsubsection{Number of Desiccants to be Tested}

Before we select the desiccants to be tested in the facility, we need to identify the maximum number of materials we can test. The desiccant samples being tested are removed from the facility to obtain a time history of their degradation. Once removed, a sample cannot be returned to the facility, because the meacurements done to obtain its sorption properties may change it. The number of samples for each desiccant depends on how many data points should be obtained for 10 months of continuous testing. We believe that five data points at intervals of $0.5,1,2,4$, and 10 months is reasonable.

At Least 2 samples of each desiccant should be tested each time in order to account for variation in properties. This amounts to 10 samples per desiccant. If possible, 2 batches of each desiccant should be tested to account for batch-to-batch variation caused by changes in manufacturing conditions. The minimum number of samples for a desiccant is 10 ; therefore, with 100 sample holders, the maximum number of different desiccants that can be tested simultaneously is 10 . Of course, as the samples are removed from the facility for sorption measurer.ents, new ones can be added and tested, thus increasing the number of data points that can be obtained for a given desiccant.

\subsubsection{Materlals Considered}

The desiccant materials suitable for solar cooling applications usually are coated on or impregnated into the walls of a dehumidifier matrix. In this investigation, we will consider desiccant materials in both bulk (i.e., particulate) form and matrix form, if possible. For example, silica gel will be tested both in bulk form, in a packed bed configuration, and in matrix form, in which silica gel particles are coated on the walls of a parallel passage test sample.

In this study we have focused on solid desiccants. Based on the industry and the 1987 DOE Solar Cooling Peer Review input, we have selected the following desiccants for investigation:

1. Microporous silica gel particles (batch A)

2. Microporous silica gel particles (batch B)

3. Microbead silica gel in parallel passage configuration

4. Fine silica gel particles in parallel passage configuration

5. $13 \mathrm{X}$ molecular sieve particles (batch $\mathrm{A}$ )

6. 13X mólecuiara sicuc particles (thatch $P$ ) 
7. Activated alumina particles

8. Activated carbon particles

9. Cargocaire lithium chloride/corrugated matrix (batch A)

10. Cargocaire lithium-chloride/corrugated matrix (batch B).

The particulate samples will be tested in a packed bed form with an average particle size of $1.5 \mathrm{~mm}$. In a packed bed configuration the first few particles facing the air flow may filter most of the particulate matter and thus guard the rest of the particles. This differs from most dehumidifier geometries considered for cooling applications. Therefore, testing of the materials in a parallel passage configuration where desiccant is coated on the walls of the passage may become critical. We will evaluate this after removing the first series of test samples.

\subsubsection{Sample Preparation}

Two batches of particulate desiccants will be tested. From each fresh batch, we will select three sample sets. The first set will be stored in a cool, dry container (as virgin samples). The second sel will be screened to an average particle size of $1.5 \mathrm{~mm}$ and then loaded in cylindrical sample test tubes for placing in the clean test cell of the desiccant contamination test facility (as clean samples). The third sct, also screened to $1.5-\mathrm{mm}$ particle size, will be loaded in test tubes for placing in the contaminated test ccll of the facility (as contaminated samples). Test tubes will be cleaned with a solvent before they are loaded with desiccant.

We expect to load about $0.5-1 \mathrm{~g}$ of desiccant into each test tube (see Figure 2-12 for a photograph of the test tube). Stainless steel screens on the ends of the tube will hold the desiccant in place. For the silica gel parallel passage configuration, the material is first coated on both sides of a double-sided mylar tape and then rolled in a sinosoidal shape and inserted into each test tube. Plastic caps put on both cnds of each tube will block off ambient air when the tube is not in the test facility. It should be noted that cach test tube has a specific label for identification. A section of the lithium-chloride/corrugated matrix of Cargocaire will be cut and inserted into the test tubes for testing. Sample test tubes will he placed in the clean and contaminated test cells.

\subsection{Test Facllity Operation}

The following steps will be taken to operate the facility (see figures in Section 2.0 for reference).

1. Prepare the desiccant sample test tubes as discussed in Section 3.1.3, and place them in the appropriate test cells. Note that each test tube holder is identified with a number and a letter (c.g., $\mathrm{A} 1$ and $\mathrm{J10}$ ) as shown in Figure 3-1 to identify where each desiccant sample is placed. The columns in clean test tubes are identified as 1 to 10 and the columns in the contaminated test tubes are identified as 11 to 20 .

2. Turn on the data-acquisition system.

3. Start the repeat cycle timer to open set A valves (globe valve numbers: $1,4,5,8$, and 9) and close set $B$ valves (globe valve numbers: $2,3,6,7$, and 10 ). 


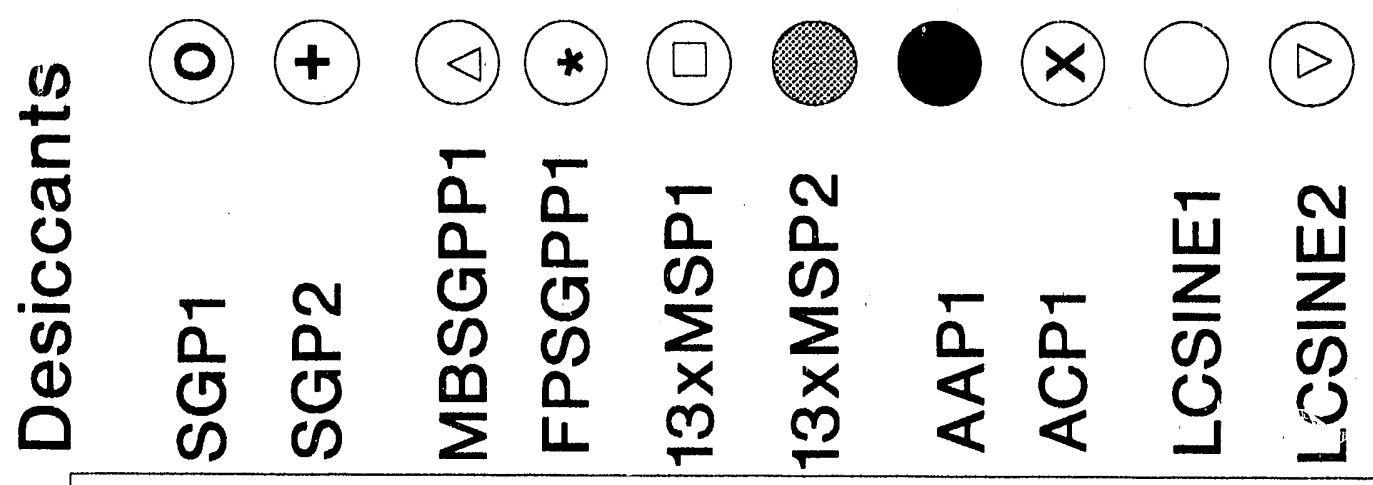

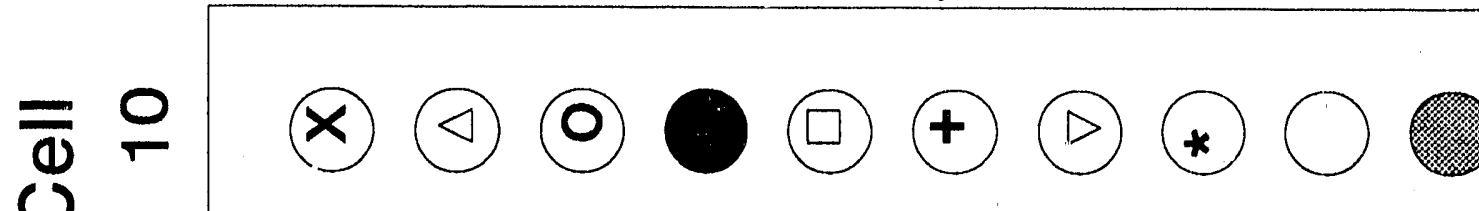

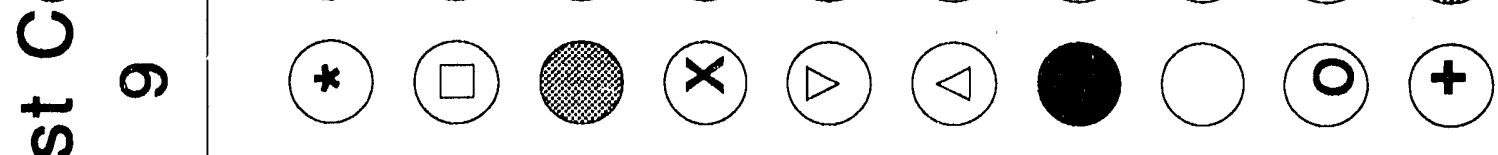

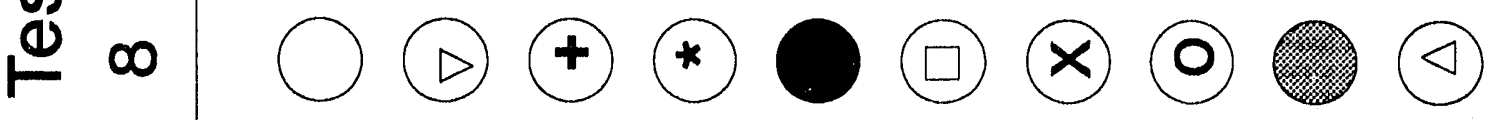

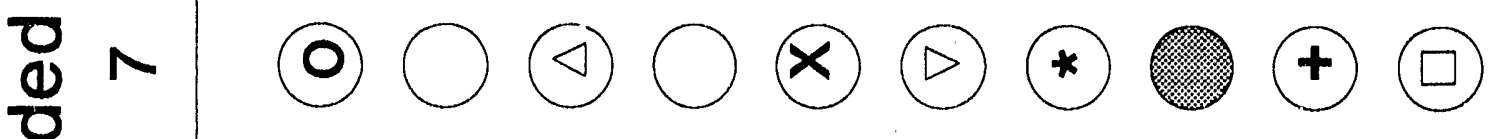

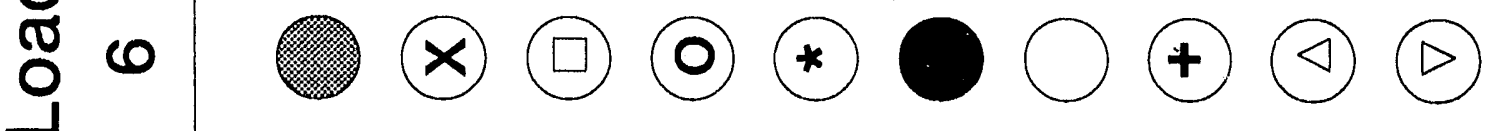

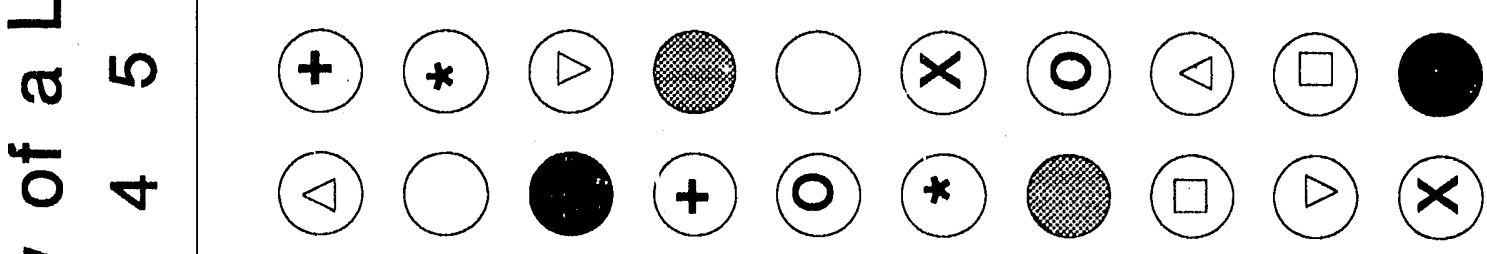

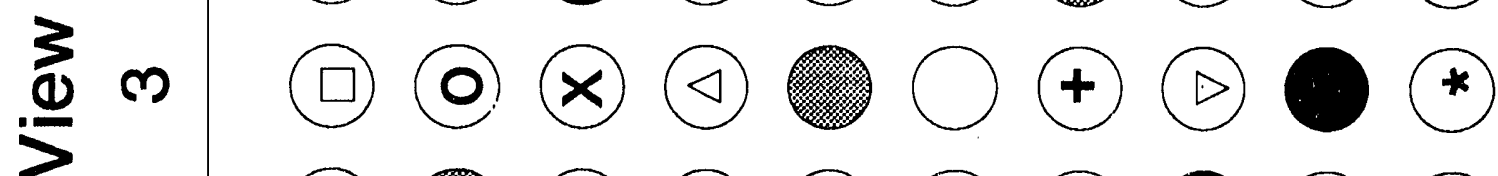

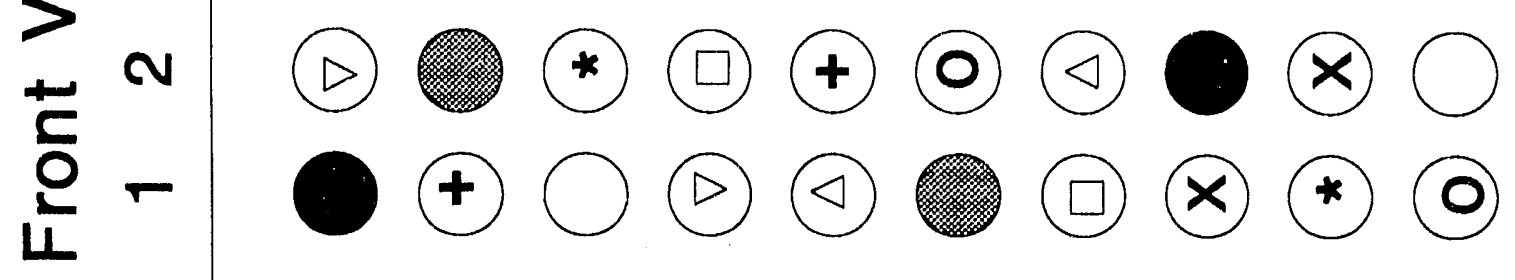

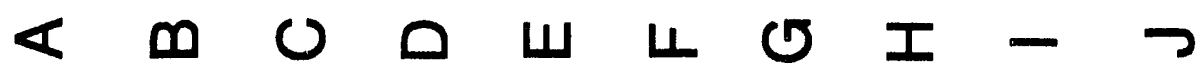


4. Turn on the blower and adjust the total flow to $40 \mathrm{cfm}$.

5. Adjust the flowmeters to supply approximately $20 \mathrm{cfm}$ air to each branch of the facility.

6. Turn on the heaters and steam humidifier.

7. Adjust the flow rate, air temperature, and air humidity to desired set-points.

8. Turn on the smoking machine (or start injecting other pollutants).

9. Set the repeat cycle timer to the appropriate cycle time for switching the hot and warm air streams between the two test cells.

10. Start the cycle counter.

11. Keep monitoring the status of the facility to assure that all components are working properly and all the experimental parameters are within the specified range.

12. Load the smoking machine with a statistically representative batch of commercially available cigarettes every three days.

13. At the proper time $(0.5,1,2,4$, or 10 months after the start of the experiment), turn off the cycle counter, heaters, steam humidifier, and blower.

14. Open the two test cells, remove the appropriate desiccant sample tubes for analysis.

15. Place new sample test tubes in place of those removed and close the test cell doors.

16. Repeat steps 4 through 15 until the first 100 samples have been processed in the facility, i.c., for 10 months.

The sorption properties of desiccant samples removed from the facility will be measured according to the outline discussed in the next section. The air flow rates, air temperatures, and air humidities will be measured and recorded on a continuous basis every minute. Selected data of several cycles in a day will be measured and stored every five seconds to ascertain the behavior of the desiccant. In this case, inlet and outlet air temperature and humidity to and from the test tubes will be measured and recorded. The pressure drop across the test cell will also be measured.

The concentration of the pollutants will be measured intermittently with the various gas analyzers. Once or twice a week, air samples from both ends of the two test cells will be drawn through the gas chromatograph for analysis. Data will be stored on floppy disks. When available, a nitrogen cold finger will also be installed to condense all the gaseous pollutants for residual gas analysis. Infrared and chemiluminescent analyzers will be used for analysis of the gases not detectable with a gas chromatograph.

\subsection{Desiccant Material Characterization}

\subsubsection{Capacity Measurements}

After the samples are removed from the clean and contaminated test cells, they will be placed in an air purge test tube holder and installed in the SERI sorption test facility to measure the adsorption and

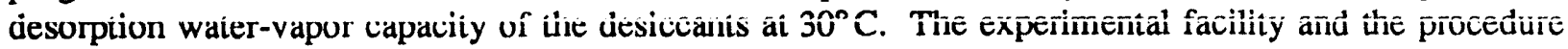
for this facility are discussed elsewhere (e.g., Bingham and Pesaran 1989). The sorption capacity of virgin 
samples will also be measured in the facility. The difference in capacity between virgin and clean samples is caused by thermal cycling. The difference in capacity between clean and contaminated samples is caused by contamination.

\subsubsection{Micrometric Measurements}

The internal structure of a porous desiccant may change as a result of contamination and thermal cycling. The pore volume, pore surface area, and pore size distribution (micrometric properties) are measures of the internal structure of a porous desiccant. We will send virgin, clean, and contaminated samples of porous desiccants to a commercial laboratory (e.g., Micrometrics in Georgia or Coors Analytical Laboratories in Colorado) for measurement of their mir,rometric properties. Differences in the results are caused by contamination and thermal cycling.

\subsubsection{Surface Analysis}

The elemental composition of the surface monolayer(s) of contaminated solids can be determined using $x$-ray photoelectron spectroscopy (Pesaran et al. 1986). This technique will be used to determine the elemental composition on the surfaces of clean and contaminated samples. Thus, we can identify the elemental composition of surface contaminants on the contaminated samples. Scanning electron microscopy also will be used on some of the samples to determine visual differences. 


\subsection{FUTURE WORK}

\subsection{Antlclpated Results}

We anticipate that we will obtain a time history of desiccant degradation from thermal cycling and cigarette smoke. We will obtain contamination data 24 hours a day for 10 months. This is equivalent to about 5 years of field testing of typical dehumidifiers (assuming that a dehumidifier operates 8 hours a day and 6 months in one year and the concentration in the field is the same as in the experiment). The desiccant degradation will be expressed as loss of moisture capacity at various humidities and by change in internal structure. The pollutants that caused the degradation will be also identified.

The loss in capacity as a function of time will be used in dehumidifier and cooling systern models to predict reduction in the performance of typical dehumidifiers and cooling systems as a function of time. Figure 4-1 depicts the anticipated hypothetical results graphically.

\subsection{Schedule}

The work has been continued in FY 1989 and FY 1990. The activities shown in Tablc 4-1 will be performed to achieve the objectives of the desiccant contamination research. The activities include SERI internal control and tracking milestones. The contamination experiment was actually started in mid-August 1989. A draft report describing the preliminary results obtained in FY 1989 was prepared. 
Desicoant Water Content

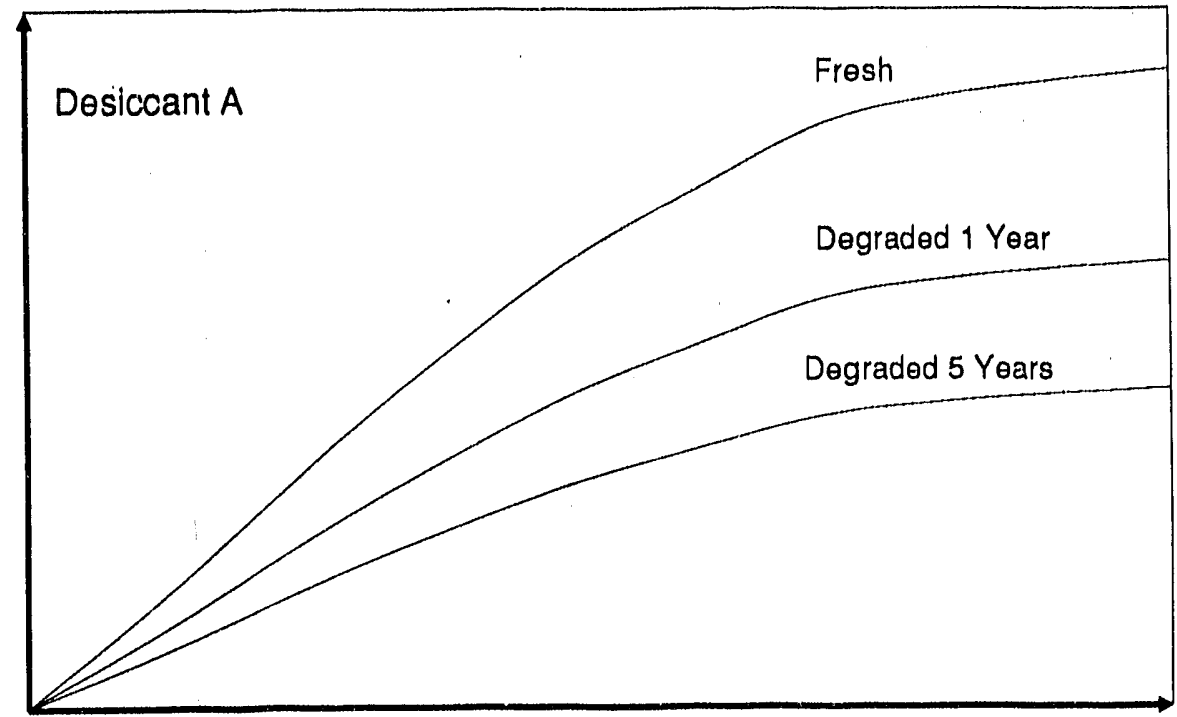

Relative Humidity

Normalized COP or Cooling Capacity

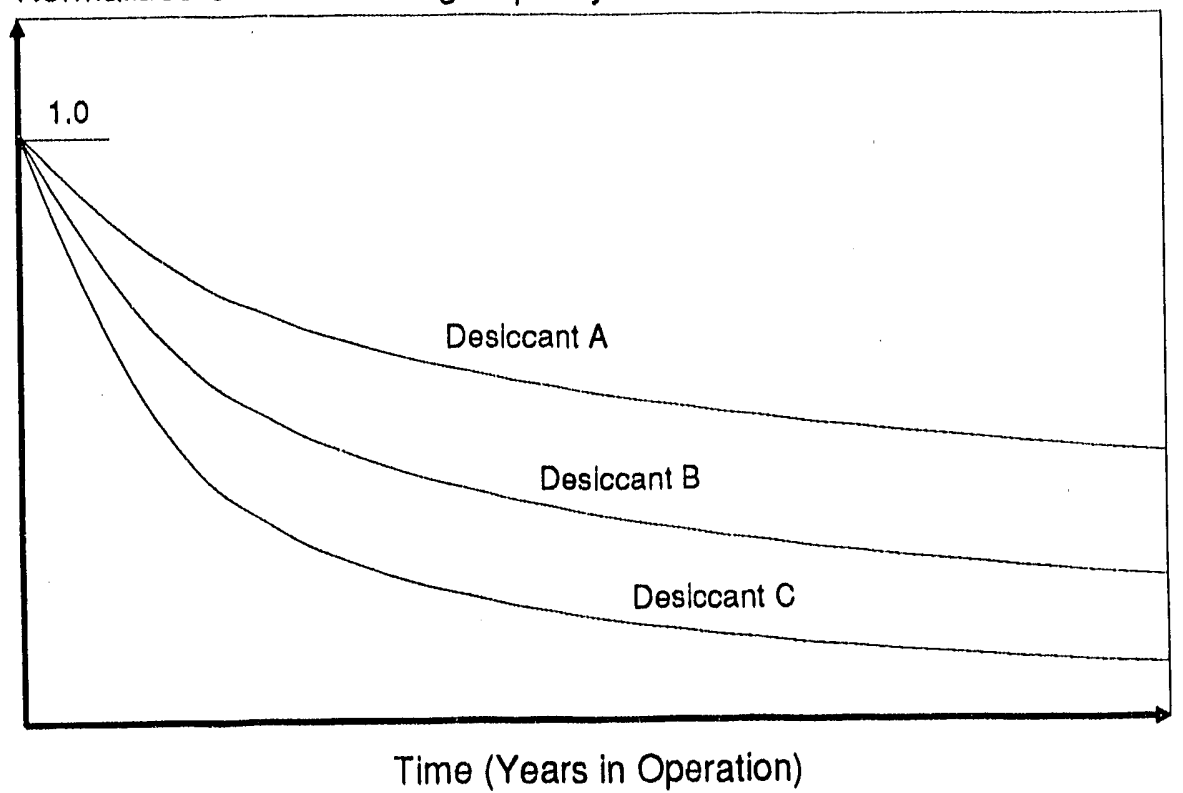

Figure 4-1. Anticipated results from the desiccant contamination research 
Table 4-1. Schedule of Activlties to Perform for Desiccant ContamInation Research In 1989

\begin{tabular}{l|l}
\hline Activity & \multicolumn{1}{l}{ Date } \\
\hline Complete fabrication of the test facility & $1 / 89$ \\
Complete assembly of data-acquisition system & $3 / 89$ \\
Complete fabrication of smoking machine & $2 / 89$ \\
Installation and shakedown of the smoking machine & $3 / 89$ \\
Shakedown of the test facility complete & $5 / 89$ \\
Secure and prepare desiccant test samples & $5 / 89$ \\
Begin contamination experiments (M) & $6 / 89 *$ \\
Continue contaminating desiccant samples & $6 / 89-12 / 89$ \\
Remove samples for sorption properties measurements & $6 / 89-12 / 89$ \\
$\begin{array}{l}\text { Prepare a letter report on preliminary results } \\
\text { on desiccant contamination tests (D) } \\
\text { Analyze removed samples }\end{array}$ & $7 / 30 / 89^{*}$ \\
$\begin{array}{l}\text { Prepare draft report on FY 1989 } \\
\text { desiccant contamination experiments (D) }\end{array}$ & $8 / 89-12 / 89$ \\
\hline
\end{tabular}

* Control milestone/deliverables

M Milestone

D Deliverable 
TP-3457 


\subsection{REFERENCES}

Bingham, C. E., and A. A. Pesaran, 1989, "Measurement Uncertainty of Adsorption Testing of Desiccant Materials and Geometries," presented at 1989 ASME Solar Energy Division Conference, San Diego, CA, April 2-5, 1989.

Farouk, S. M., G. H. Brusewitz, and P. D. Bloome, 1980, "Desiccant Moisture Sorption as Altered by Dust," ASAE, Paper No. 80-3084.

Moseman, M. H., and G. Bird, 1982, "Desiccant Dehydration of Natural Gasoline," Chemical Engineering Program, Vol. 78, No. 2, pp. 78-83.

Pesaran, A. A., 1987, "Desiccant Materials Contamination Research Plan," June 1987, Letter Report to DOE, Golden, CO: Solar Energy Research Institute.

Pesaran, A. A., 1988, "Review of the Design of the Desiccant Contamination Research Facility (DCTF)," Memo to T. Penney dated May 18, Golden, CO: Solar Energy Research Institute.

Pesaran, A. A., and B. K. Parsons, Dec. 1987, "Status Report on Desiccant Materials Contamination Research," SERI/PR-254-3398, Golden, CO: Solar Energy Research Institute.

Pesaran, A. A., T. Thomas, T. Penney, and A. Czanderna, Sept. 1986, "Methods to Quantify Contamination Effects on Silica Gel Samples," SERI/TR-252-2802, Golden, CO: Solar Energy Research Institute. 
APPENDIX A

VIEWGRAPHS OF FY 1988 PRESENTATION TO DOE SOLAR DESICCANT COOLING PEER REVIEW 


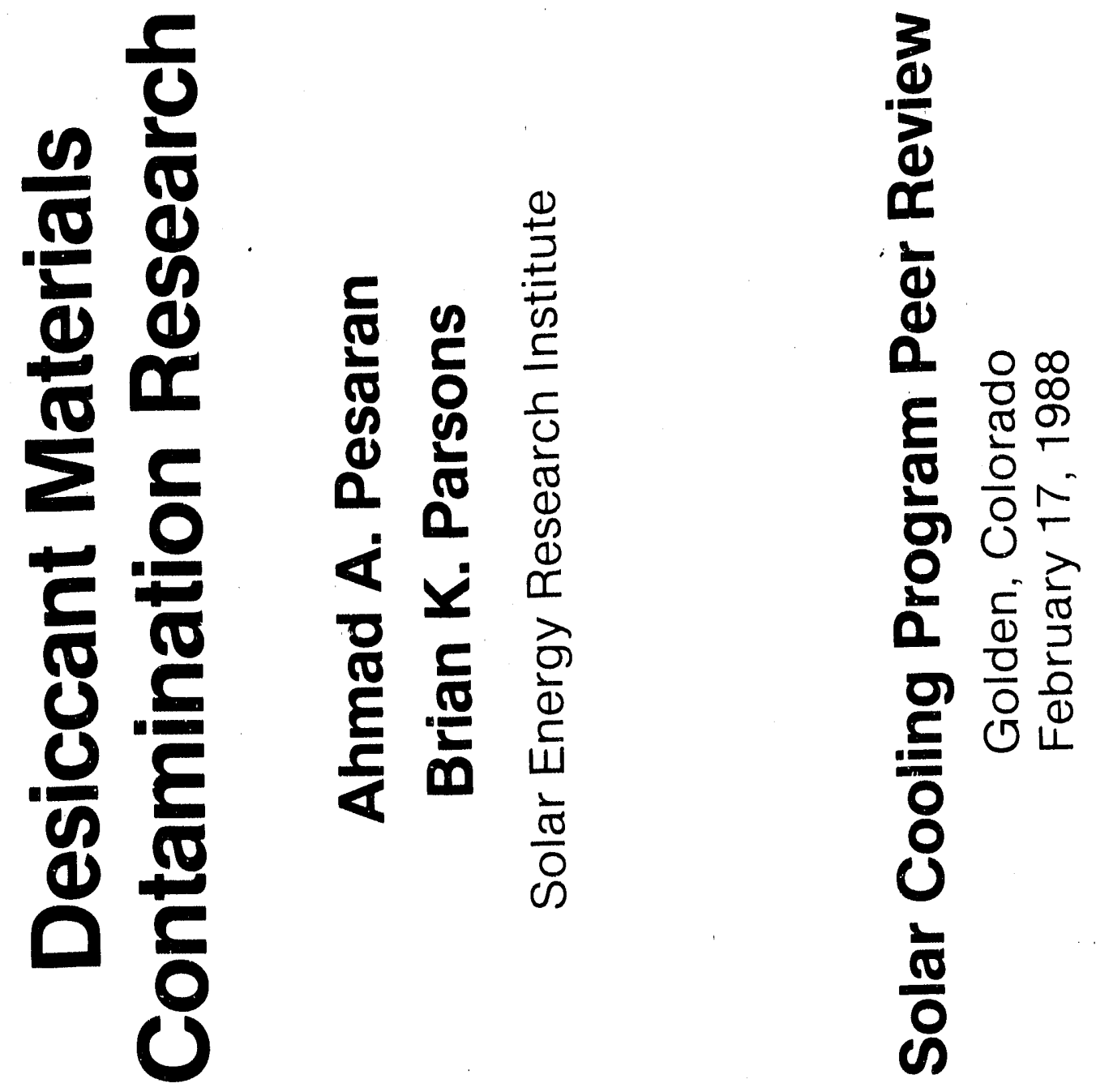




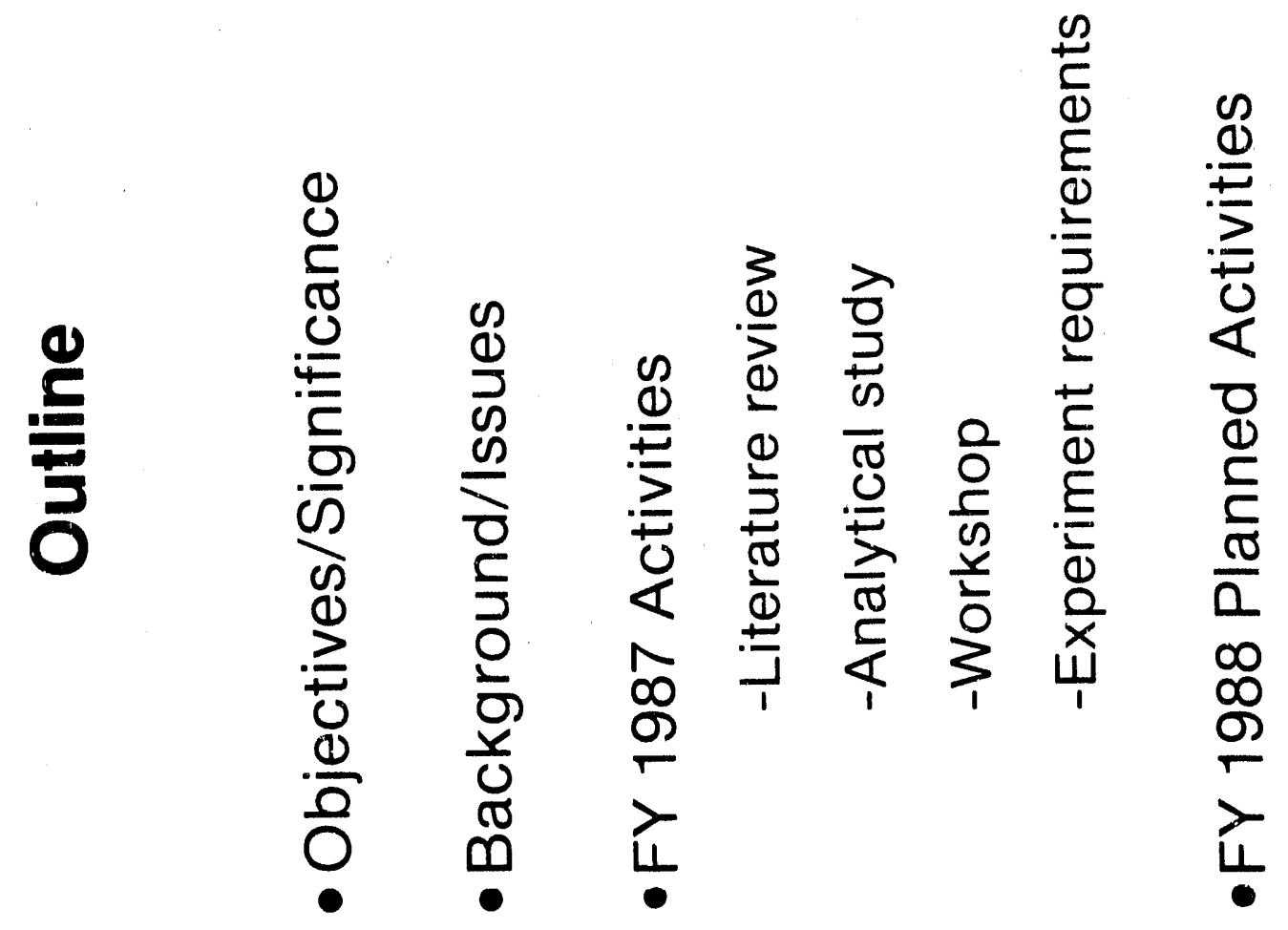



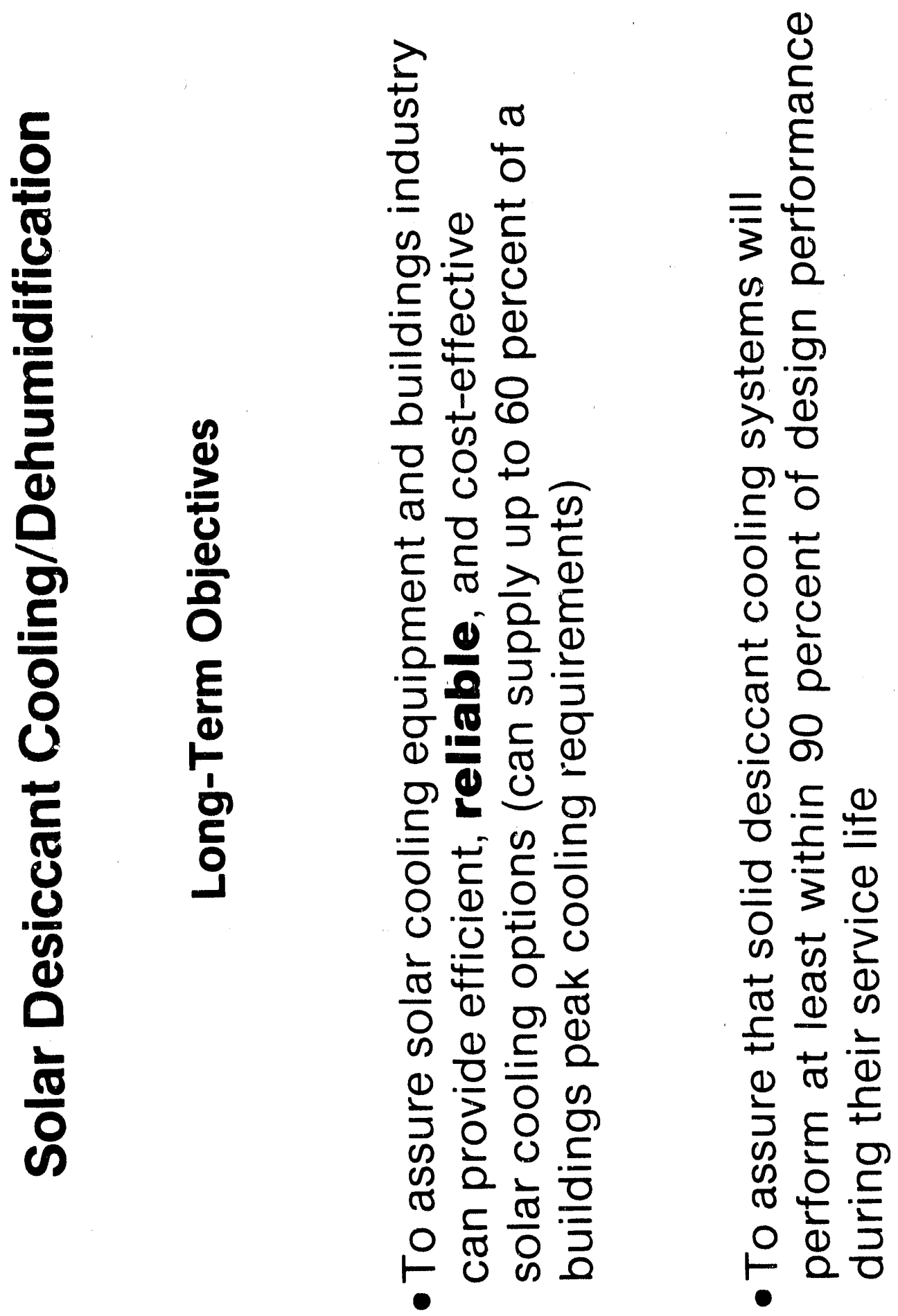

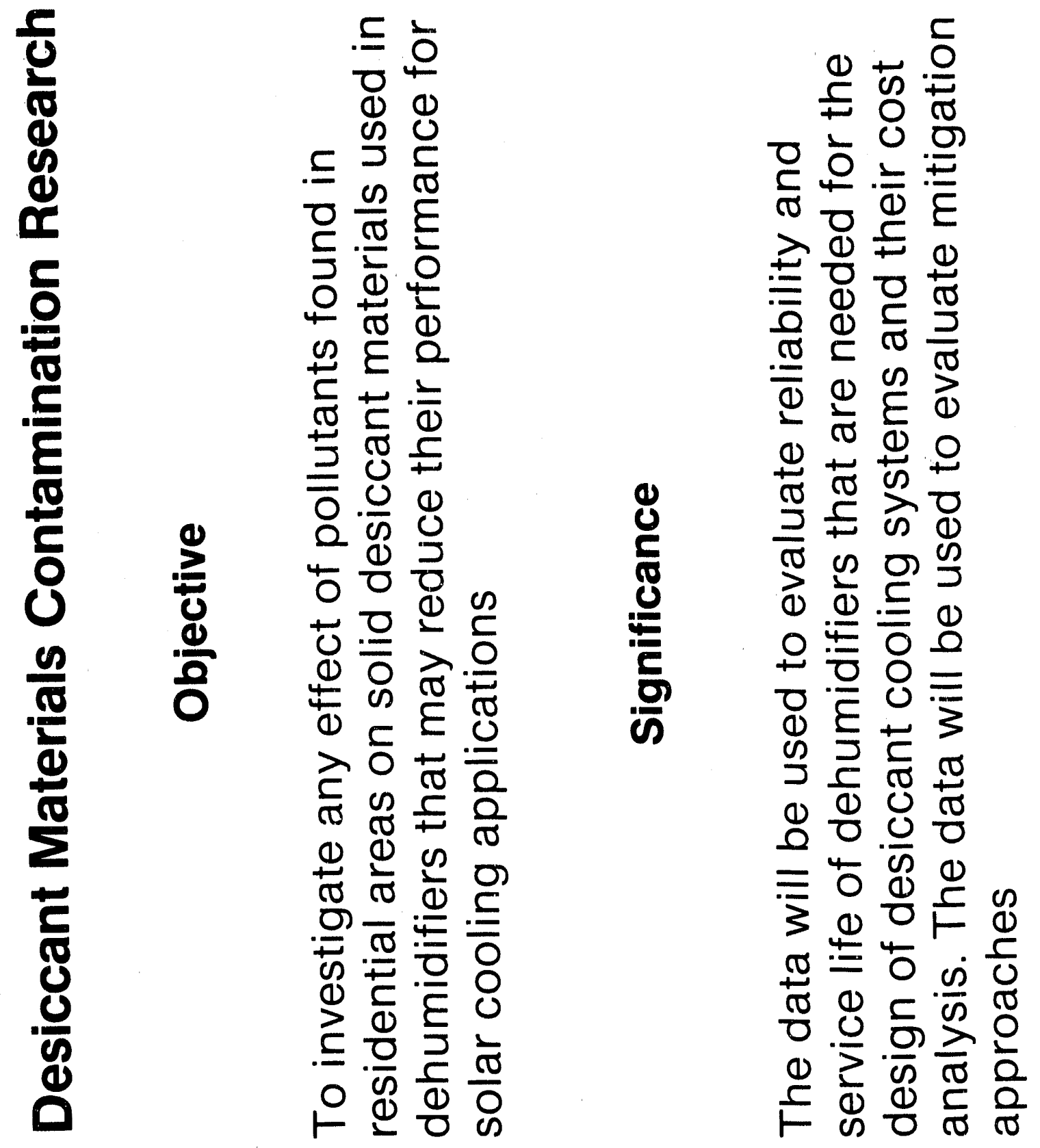


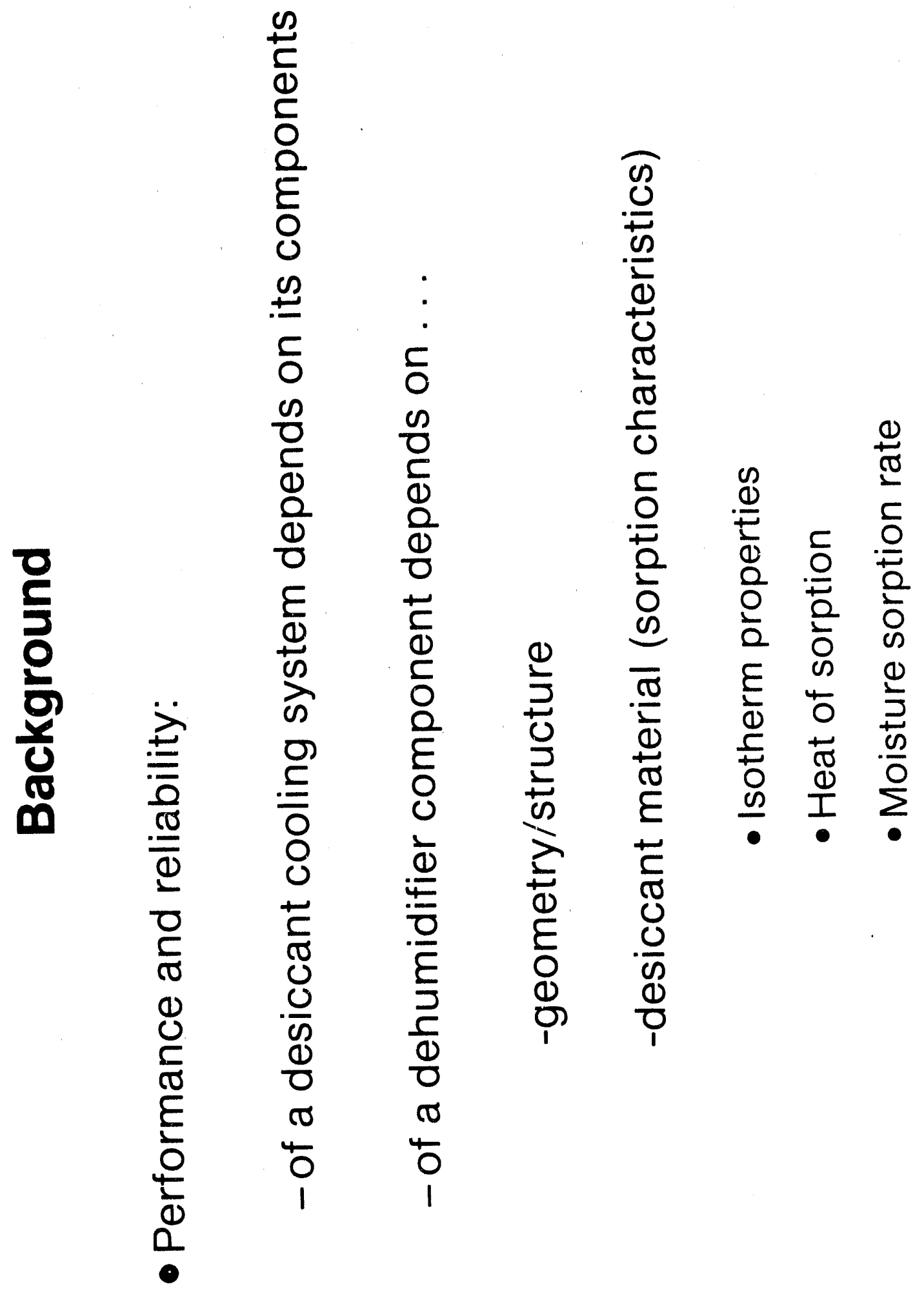




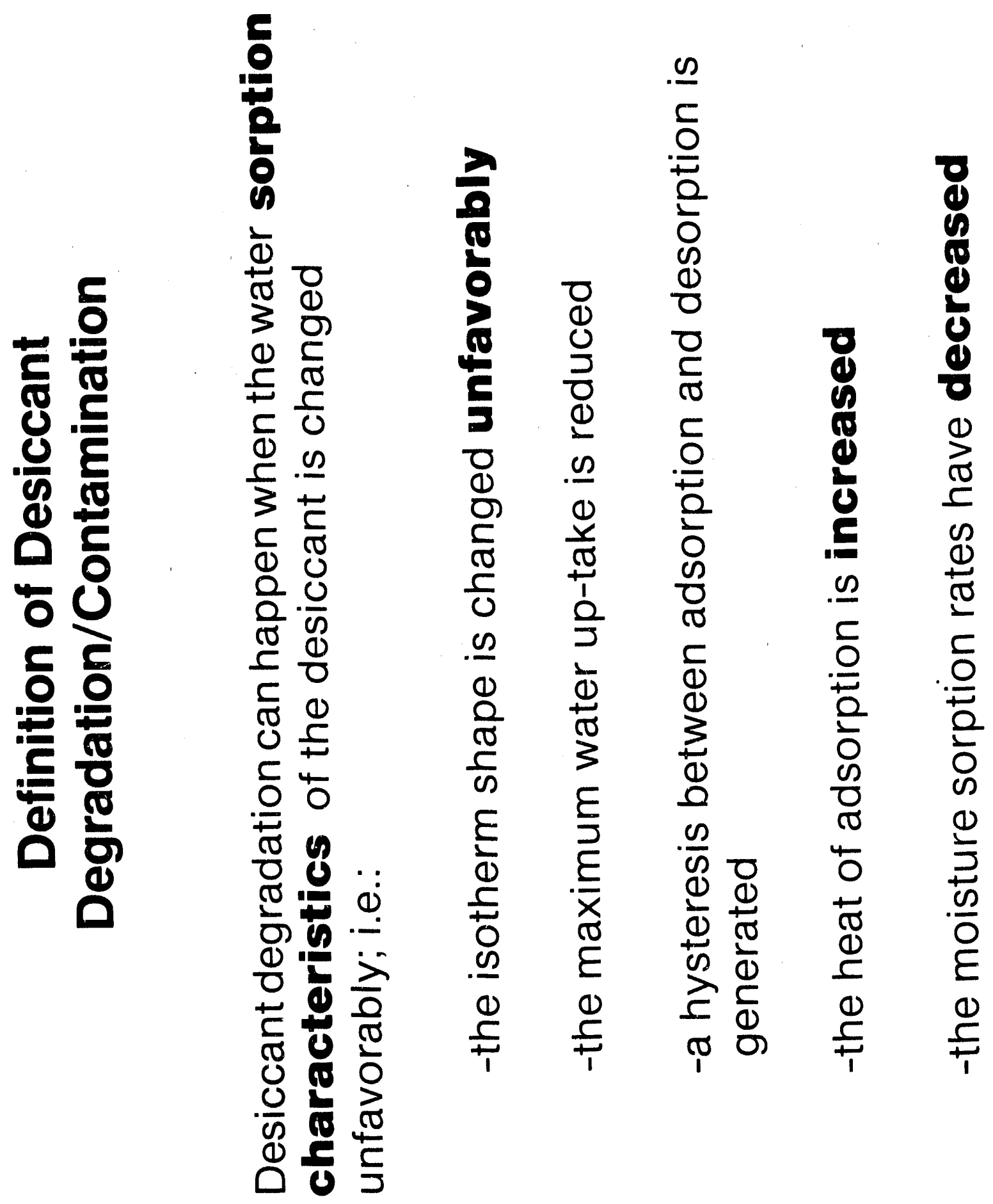




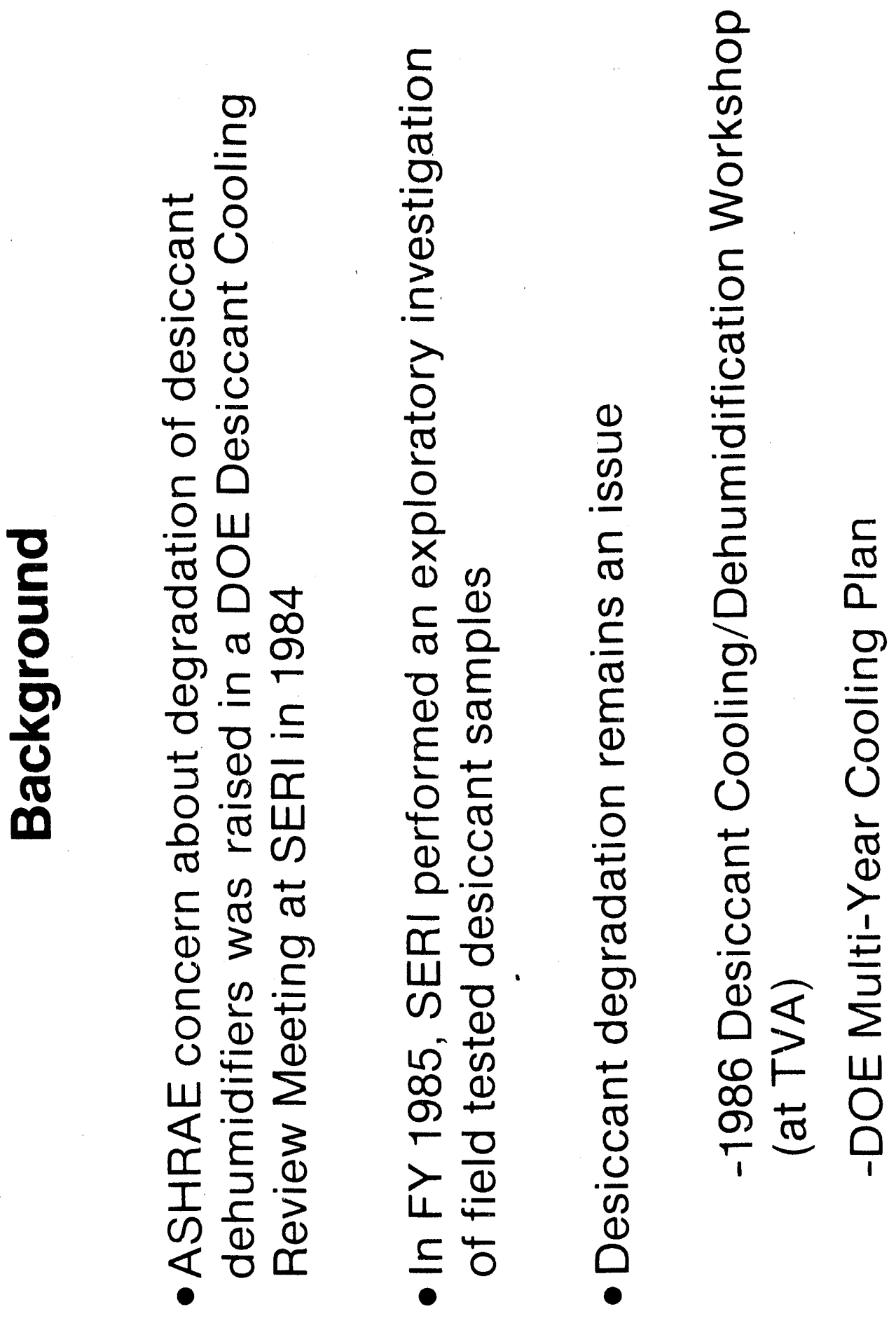




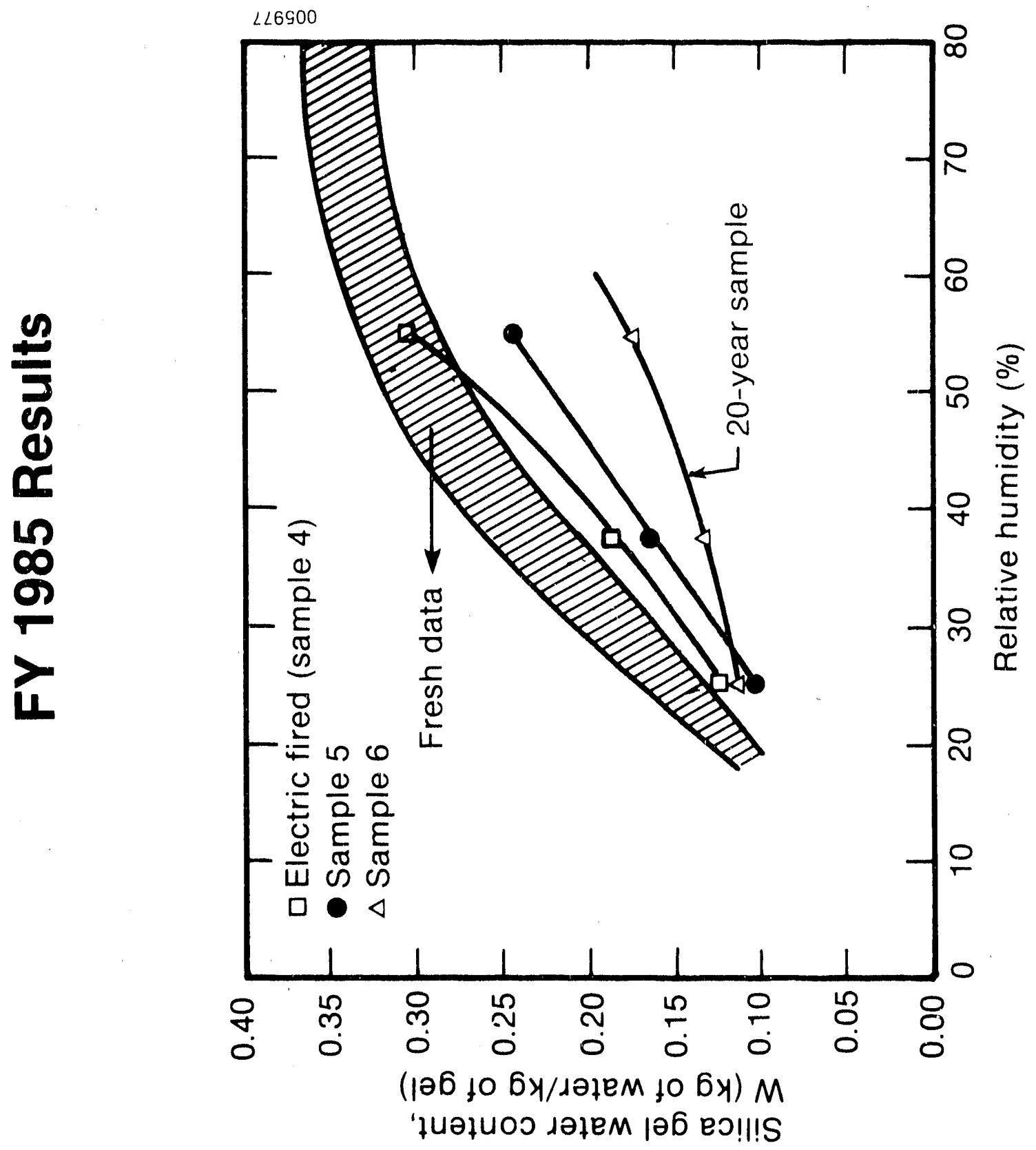


TP-3457

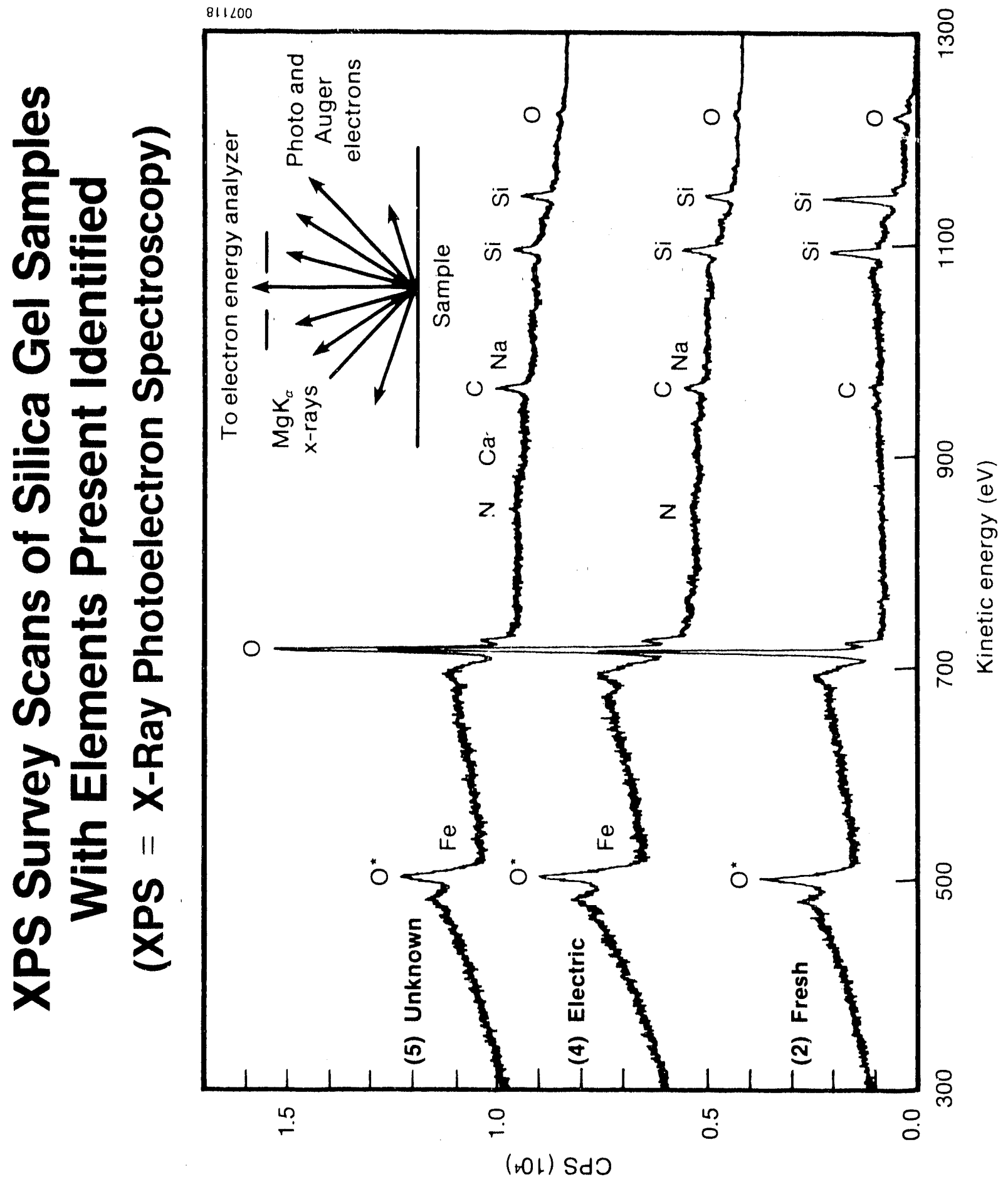




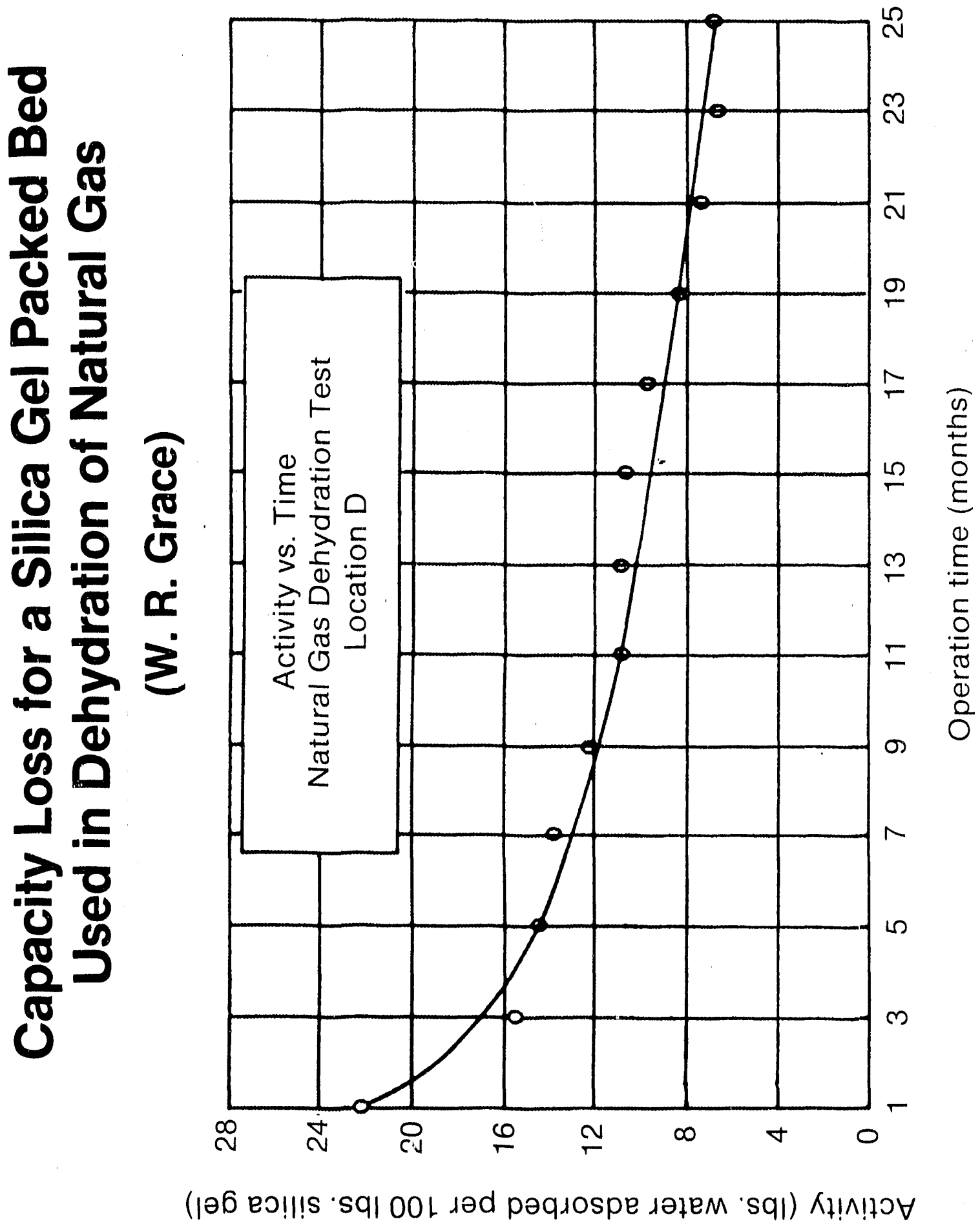


TP-3457

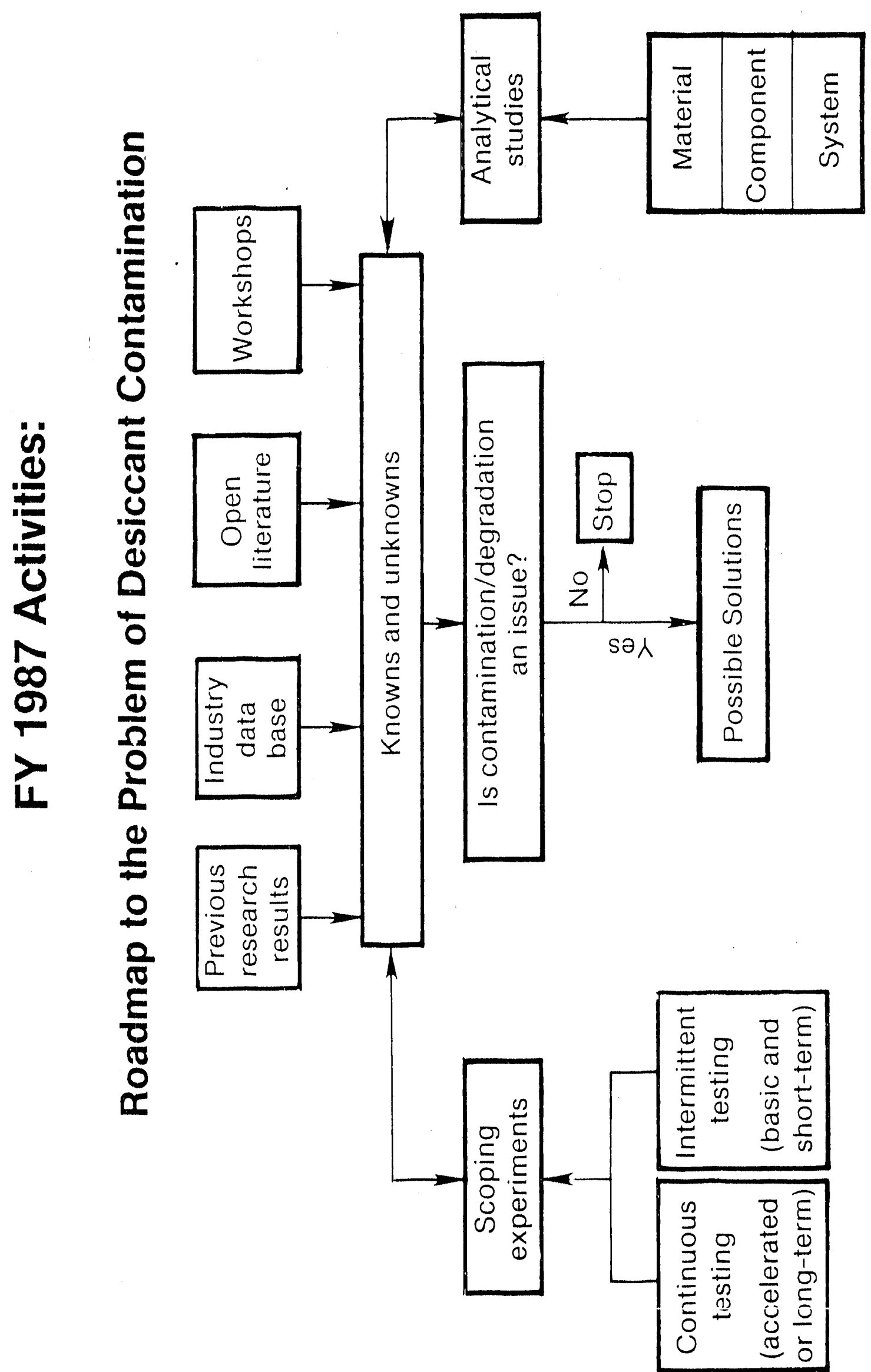




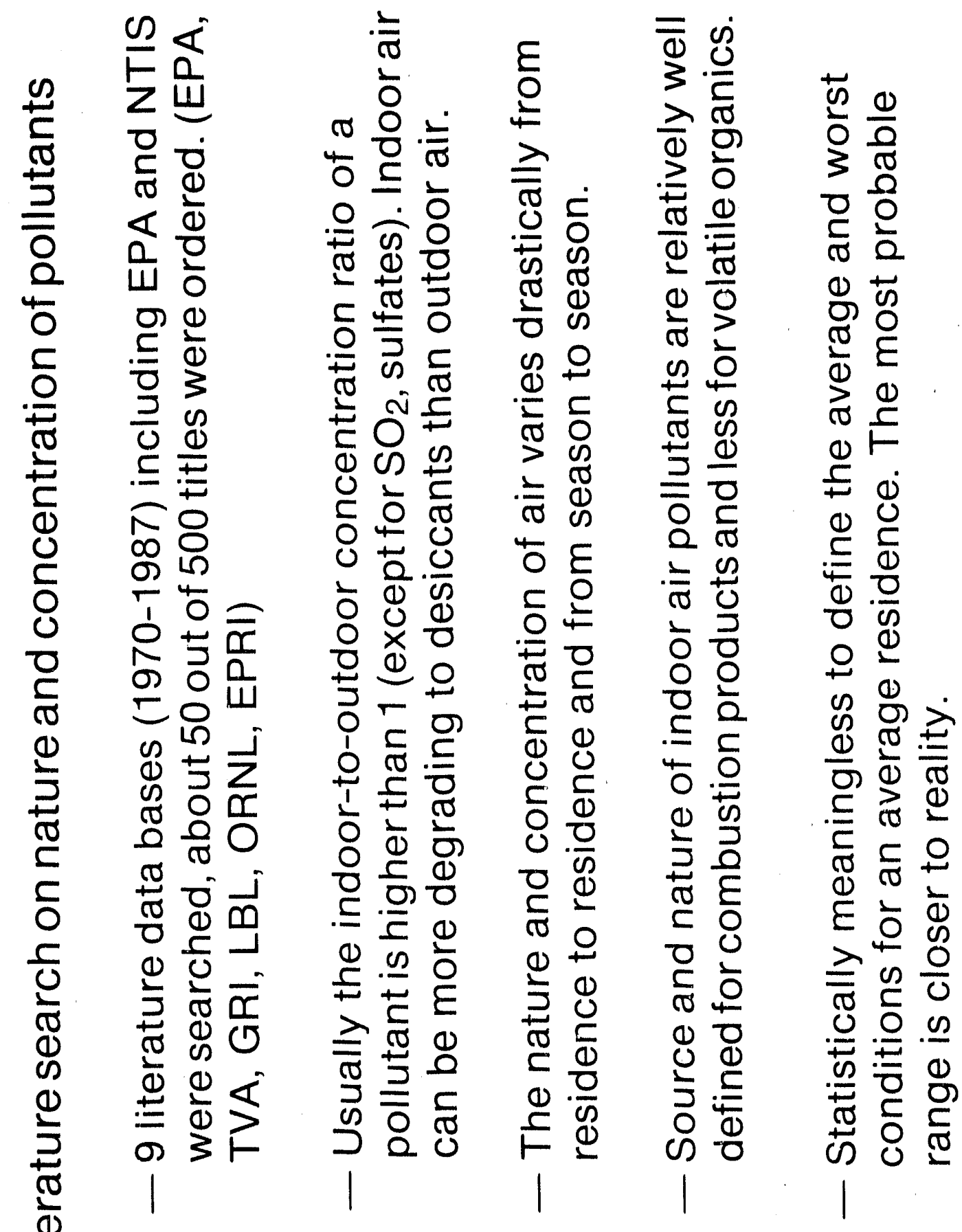



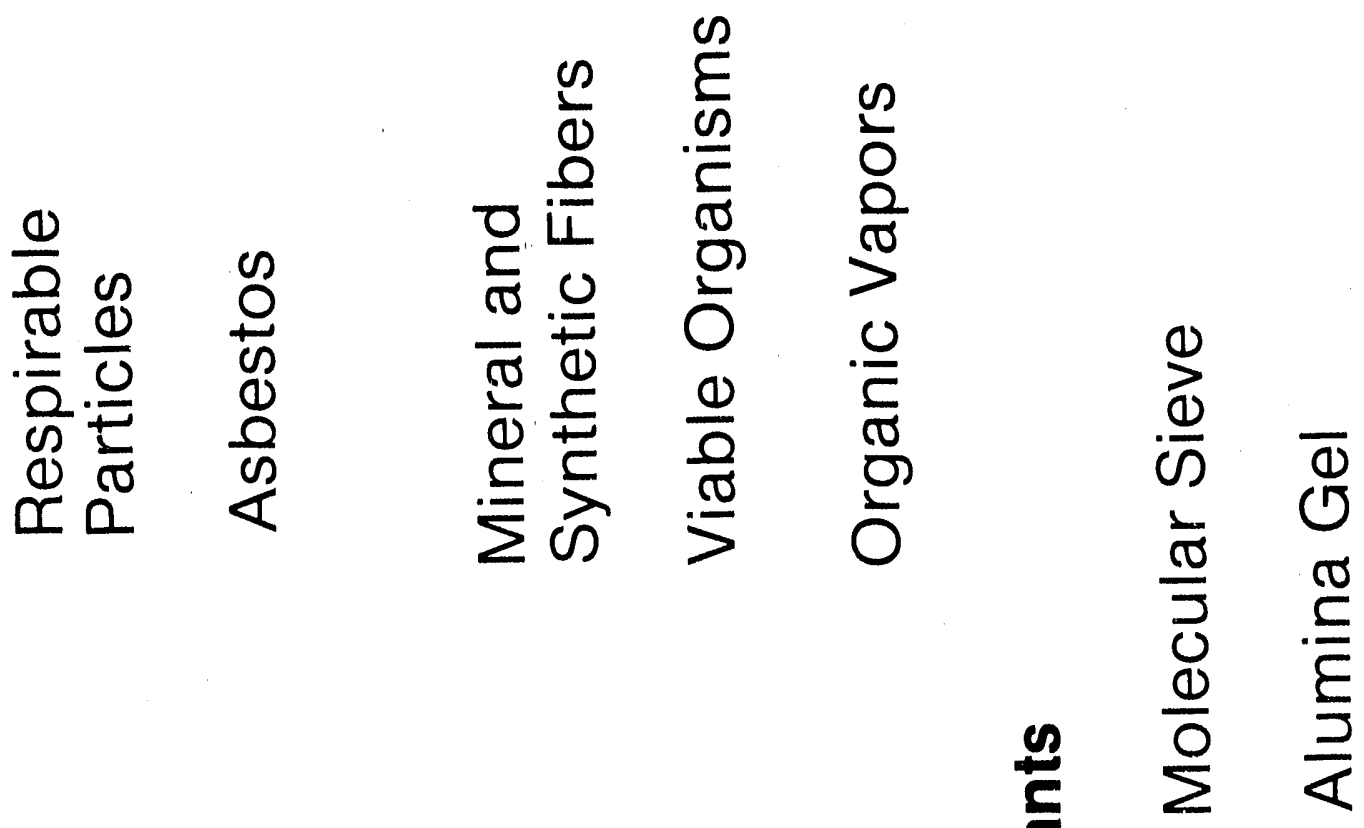

$\frac{0}{\frac{0}{5}}$

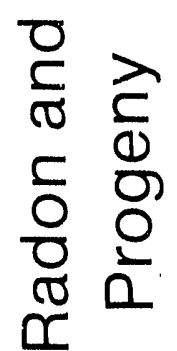

0
$\frac{1}{0}$
$\frac{1}{0}$
$\frac{0}{\sigma}$
$\frac{E}{0}$
4

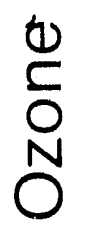

$\frac{0}{0}$
$\frac{x}{0}$
$\frac{0}{0}$
$\frac{0}{2}$
$\frac{5}{0}$
$\frac{0}{1}$
0
0
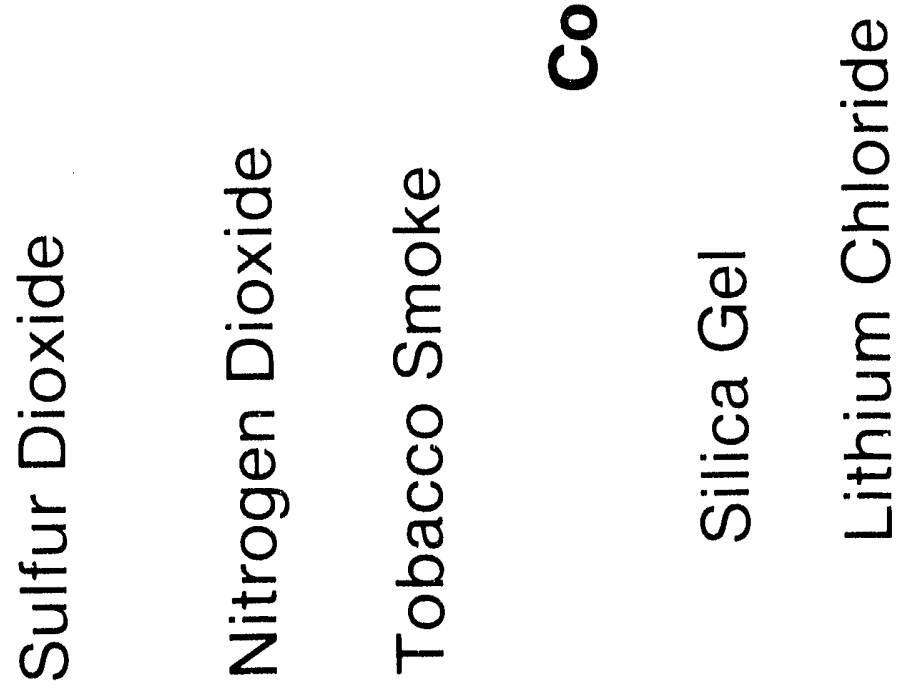

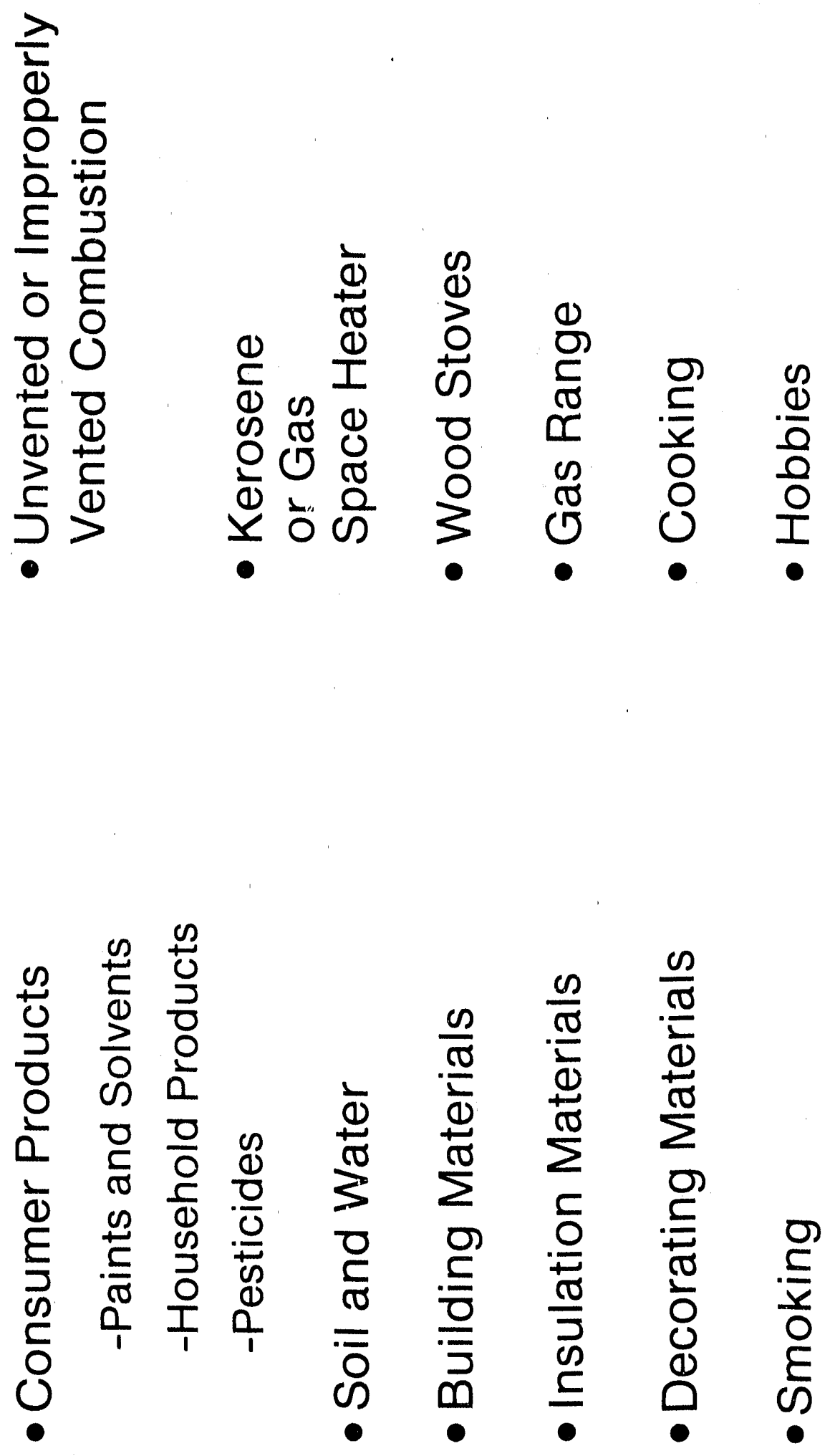
Sources, Possible Concentrations, and Indoor-to-Outdoor Concentration Ratios of Some Indoor Pollutants

\begin{tabular}{|c|c|c|c|c|}
\hline Pollutant & $\begin{array}{l}\text { Sources of } \\
\text { Indoor Pollueton }\end{array}$ & $\begin{array}{l}\text { Possible Indoor } \\
\text { Concentrat1on }\end{array}$ & $\begin{array}{l}\text { I/0 Con- } \\
\text { centration } \\
\text { Rat10 }\end{array}$ & Locat1on \\
\hline Carbon monoxide & $\begin{array}{l}\text { Combustion equip } \\
\text { ment, engines, } \\
\text { faulty beat1ng } \\
\text { oystem }\end{array}$ & $100 \mathrm{ppm}$ & $\gg 1$ & $\begin{array}{l}\text { Skat1ng riaks, } \\
\text { offlces, homes, } \\
\text { cars, shops }\end{array}$ \\
\hline $\begin{array}{l}\text { Resplrable } \\
\text { particles }\end{array}$ & $\begin{array}{l}\text { Stoves, fire- } \\
\text { places, c1gar- } \\
\text { cttes, conden- } \\
\text { pet1on of } \\
\text { volat1les, } \\
\text { aerosol bprays, } \\
\text { resuspension, } \\
\text { cookdag }\end{array}$ & $100-500 \sim 8 / m^{3}$ & $\gg 1$ & $\begin{array}{l}\text { Howes, offlces, } \\
\text { cars, public } \\
\text { facilities, bars, } \\
\text { restaurants }\end{array}$ \\
\hline Organlc vapors & $\begin{array}{l}\text { Combustion, } \\
\text { solvents, resin } \\
\text { products, pest1- } \\
\text { c1des, gerosol } \\
\text { sprays }\end{array}$ & MA & $>1$ & $\begin{array}{l}\text { Howes, restau- } \\
\text { radis, public } \\
\text { facilities, } \\
\text { offices, hospltals }\end{array}$ \\
\hline N1Erogen dioxide & $\begin{array}{l}\text { Combustion, gas } \\
\text { stoves, water } \\
\text { heaters, dryers, } \\
\text { c1garettes, } \\
\text { englues }\end{array}$ & $200-1,000 \mu 8 / \mathrm{m}^{3}$ & $\gg 1$ & $\begin{array}{l}\text { Lomes, skating } \\
\text { rink.s }\end{array}$ \\
\hline Sulfur dioxdde & Beating system & $20 \mu 8 / m^{3}$ & $<1$ & Removal Inside \\
\hline $\begin{array}{l}\text { Total suspended } \\
\text { particles with- } \\
\text { out rooking }\end{array}$ & $\begin{array}{l}\text { Combustion, re- } \\
\text { suspension, } \\
\text { heating eystem }\end{array}$ & $100 \mu \mathrm{H} / \mathrm{m}^{3}$ & 1 & $\begin{array}{l}\text { Homes, offlces, } \\
\text { trarsportat1on, } \\
\text { restaurants }\end{array}$ \\
\hline Sulfate & $\begin{array}{l}\text { Katches, gas } \\
\text { stoves }\end{array}$ & $5 \mu 8 / \mathrm{m}^{3}$ & $a$ & Removal Inside \\
\hline Forsol de hy de & $\begin{array}{l}\text { Insulation, pro- } \\
\text { duct binders, } \\
\text { pertlcleboard }\end{array}$ & $0.05-1.0 \mathrm{ppm}$ & $>1$ & Homes, offices \\
\hline $\begin{array}{l}\text { Radon and } \\
\text { progeny }\end{array}$ & $\begin{array}{l}\text { Bullding } \\
\text { mater1als, } \\
\text { groundwater, so11 }\end{array}$ & $0.1-30 \mathrm{nC1} / \mathrm{m}^{3}$ & $\gg 1$ & Homes, bulldiags \\
\hline
\end{tabular}




\begin{tabular}{|c|c|c|c|c|}
\hline Pollutant & $\begin{array}{l}\text { Sources of } \\
\text { Indoor Pollur1on }\end{array}$ & $\begin{array}{l}\text { Possible Indoor } \\
\text { Concentration }\end{array}$ & $\begin{array}{l}\text { I/0 Con- } \\
\text { Centrat1od } \\
\text { Rat10 }\end{array}$ & Location \\
\hline Asbestos & F1reproof1ng & I flber/cc & 1 & $\begin{array}{l}\text { Bomes, schools, } \\
\text { offlces }\end{array}$ \\
\hline $\begin{array}{l}\text { Mineral and } \\
\text { aynthet1c flbers }\end{array}$ & $\begin{array}{l}\text { Products, } \\
\text { cloth, rug8, } \\
\text { wallboard }\end{array}$ & MA & - & $\begin{array}{l}\text { Bowes, schools, } \\
\text { offlces }\end{array}$ \\
\hline Carbon dioxide & $\begin{array}{l}\text { Combustion, } \\
\text { humase, pets }\end{array}$ & $3,000 \mathrm{ppm}$ & $\gg 1$ & $\begin{array}{l}\text { Homes, schools, } \\
\text { offlces }\end{array}$ \\
\hline $\begin{array}{l}\text { V1able organ- } \\
\text { 18mb }\end{array}$ & $\begin{array}{l}\text { Humans, pets, } \\
\text { rodents, lnsects, } \\
\text { plants, fungl, } \\
\text { humld1flezs, a1s } \\
\text { condl t1oners }\end{array}$ & $M$ & 21 & $\begin{array}{l}\text { Homes, hospltals, } \\
\text { schools, offlces, } \\
\text { publ1c fac1l1ties }\end{array}$ \\
\hline Ozone & $\begin{array}{l}\text { Electrle arcing, } \\
\text { UV l1ght sources }\end{array}$ & $\begin{array}{r}20 \mathrm{ppb} \\
200 \mathrm{PPb}\end{array}$ & $\begin{array}{l}<1 \\
21\end{array}$ & $\begin{array}{l}\text { Afrplanes } \\
\text { Offlces }\end{array}$ \\
\hline
\end{tabular}

aconcentratlous $118 t e d$ are only 11lustrative of those reported 1ndoors. Both h1gher and lower concentrations have been neasured. No averaglng times are glven. NA, not appropriate to $115 t$ a concentration. 
芯

웜

ल ब

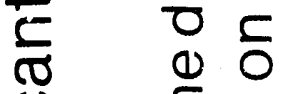

U

ज प

8 O

(1) ᄃ

2000

N 0

$\pm \quad 0$ क

त)

$\pm \quad$ क

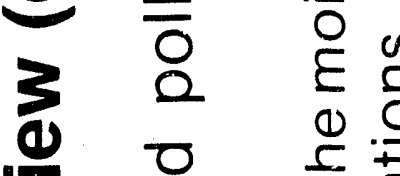

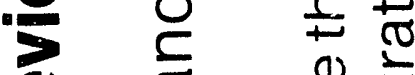

ब त

๘

(1)

$3 \quad 0 \quad 0$

ए

तथ 0 ठ휴

$\stackrel{ }{ \pm} \stackrel{0}{ \pm}$

$\exists$ च

융 $\stackrel{\frac{\pi}{2}}{\frac{0}{0}} \frac{0}{\frac{1}{1}}$

రั

ó

U
유 बे

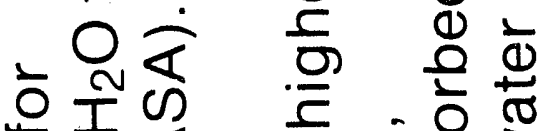

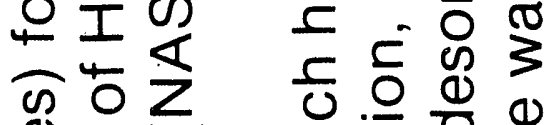

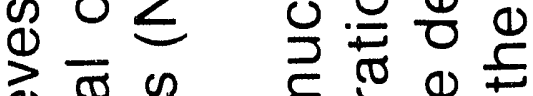

खे

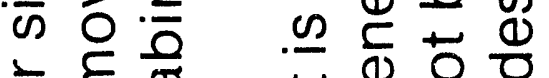

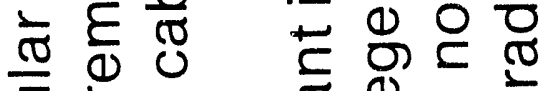

$\bar{\supset} \div 0$

$\frac{1}{0} \stackrel{0}{0}$ 虫

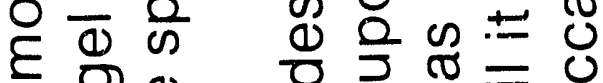

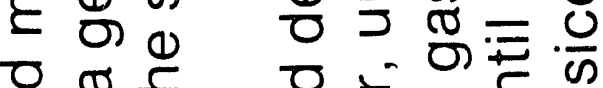

음

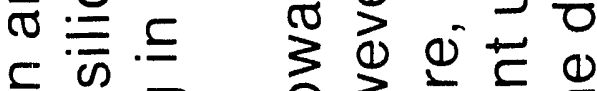

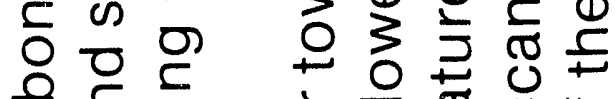

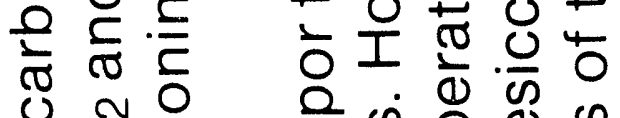

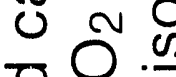

잉

응 i 응 \&

$>$ ल

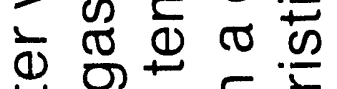

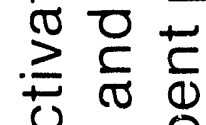

언

$\because 0 \overline{0}$

N

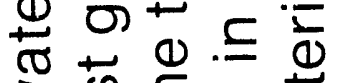

उ

ப $\varepsilon \frac{\sigma}{0} \frac{\pi}{\sigma}$

त० ण है

$\frac{1}{\pi} \div$

元

D

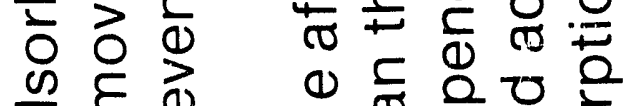

বेष

ఏ $\frac{1}{6}$ 인

F兵过 宁
ᄃ

엉

응 $\frac{0}{0} \quad$ 응

응 은

ช

\&

क ⿻ ㇒ 는

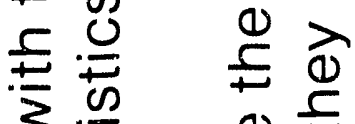

屯

(1) ช্రে ब ब

츙

다요

등응 욤

है

힝 ह 잉

ट क

สิ N

E 으응 음

$\stackrel{0}{ \pm} \quad$ क

ᄃ 1 थ

폰 은 능

兗元

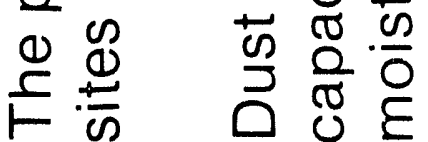




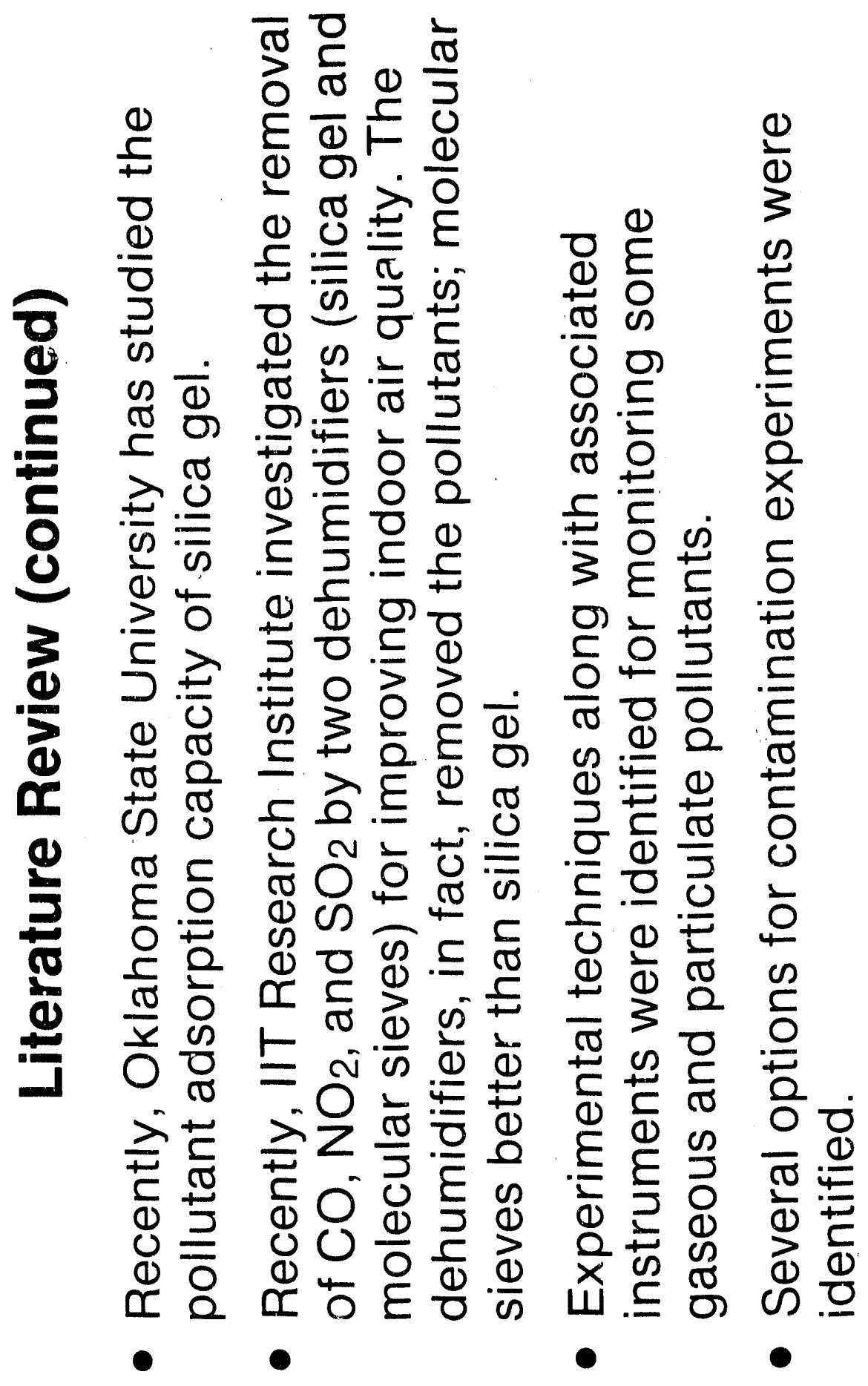



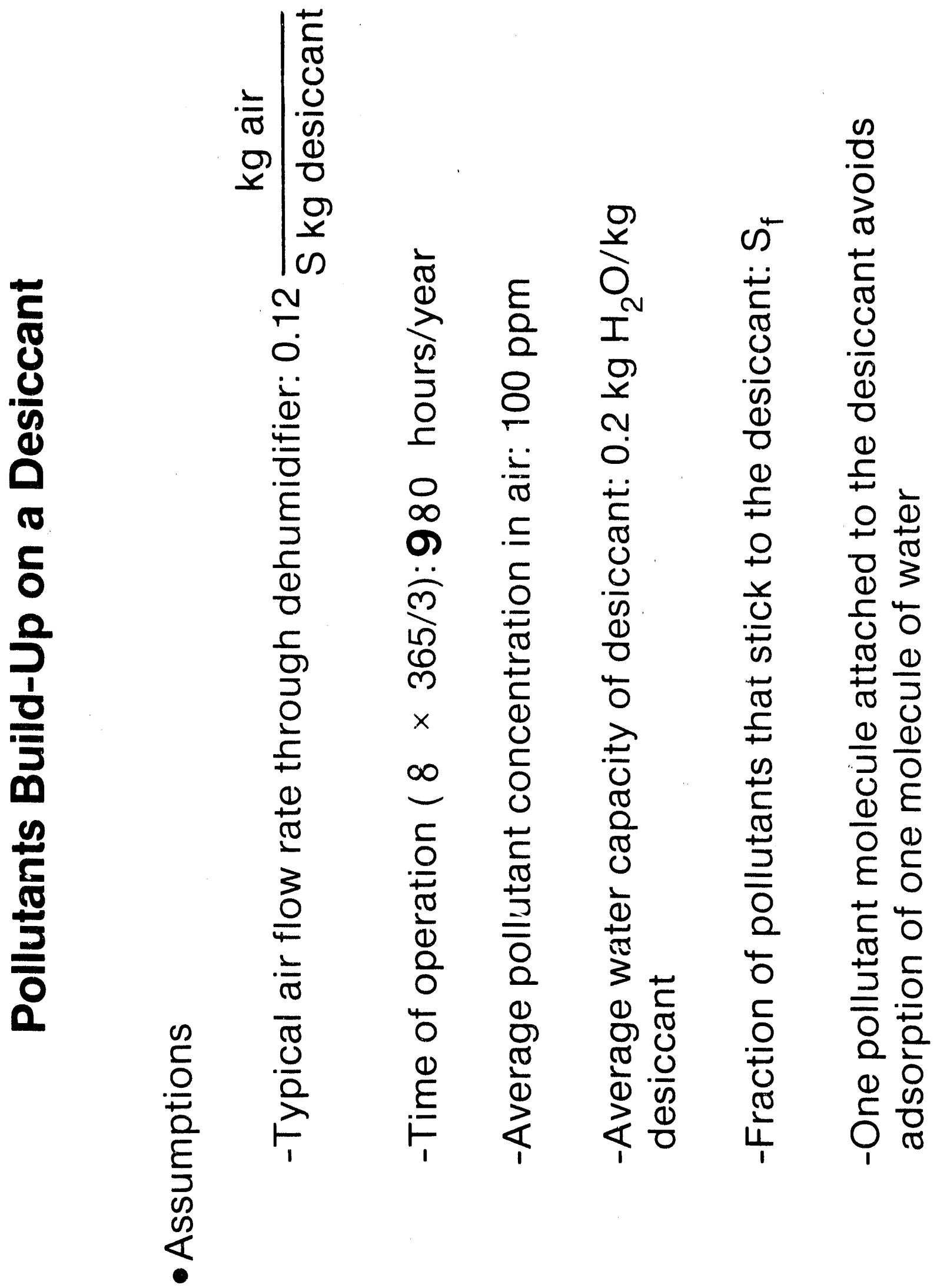


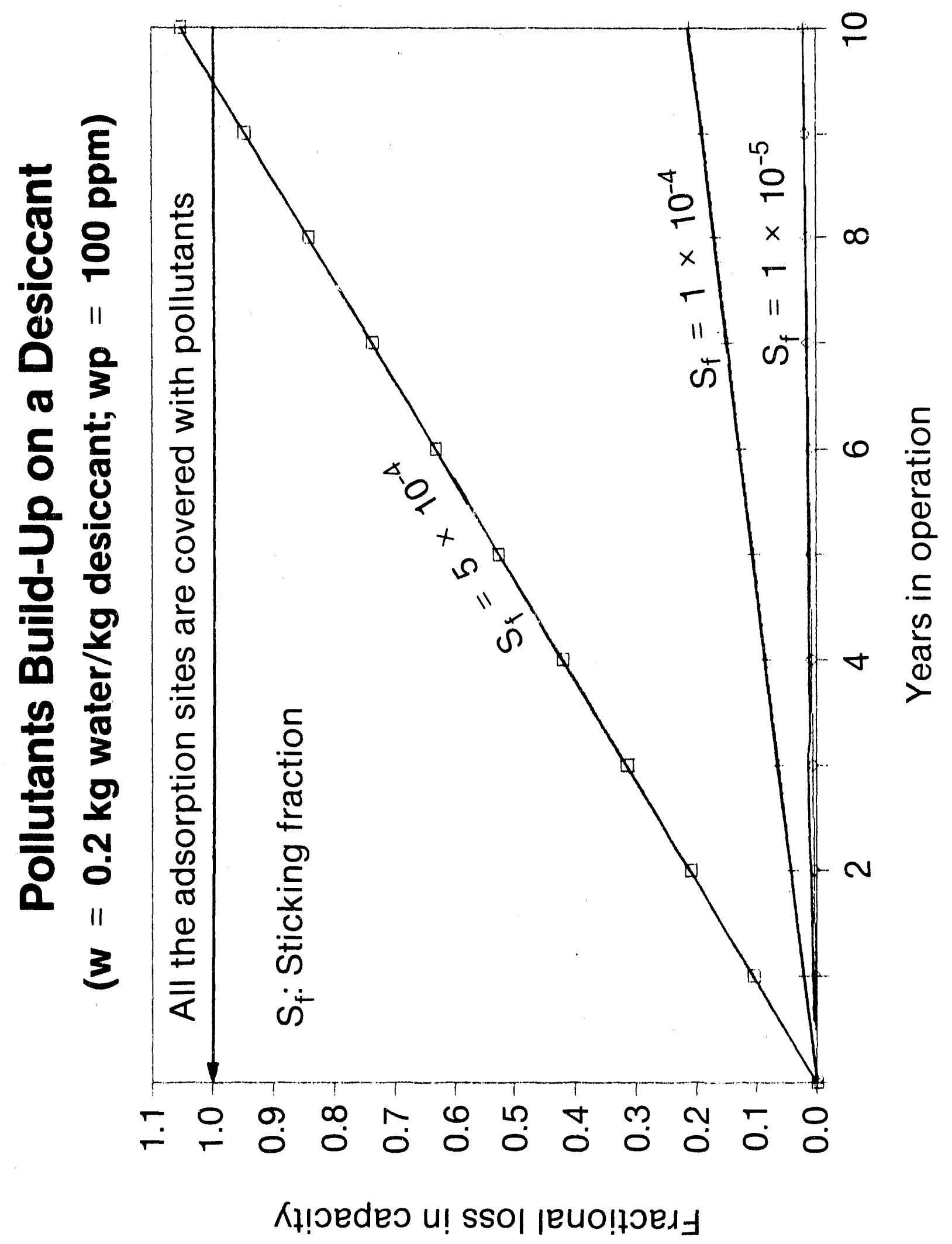




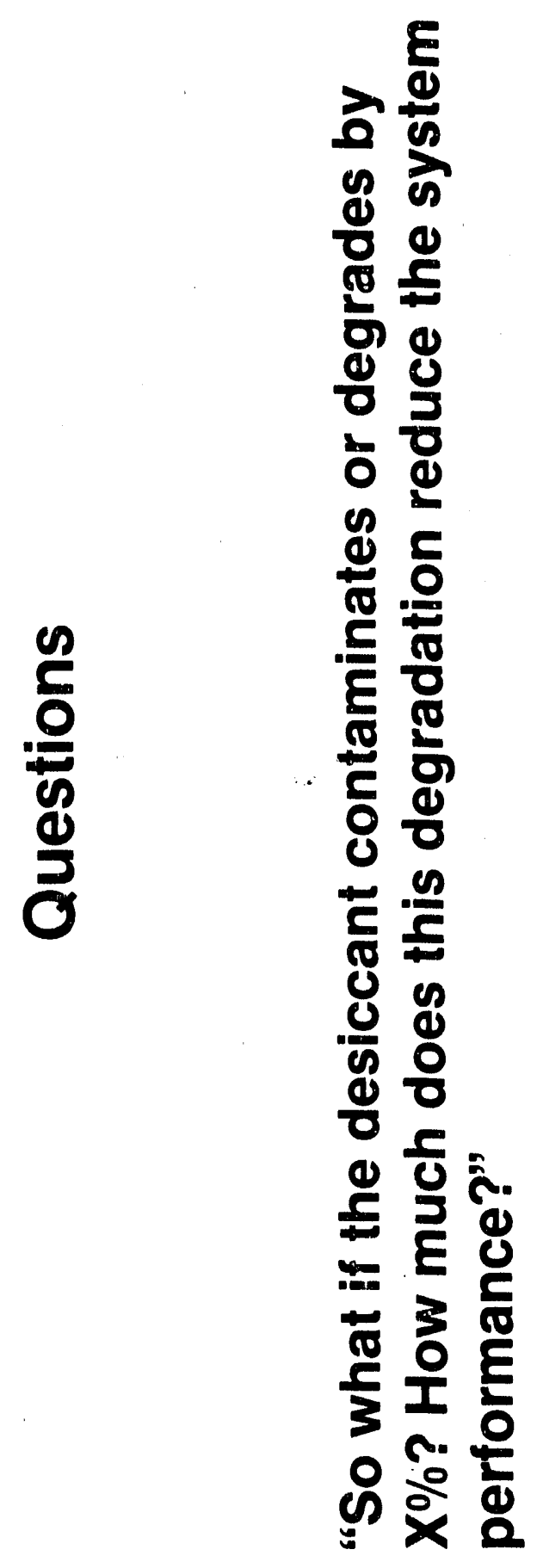

A-22 


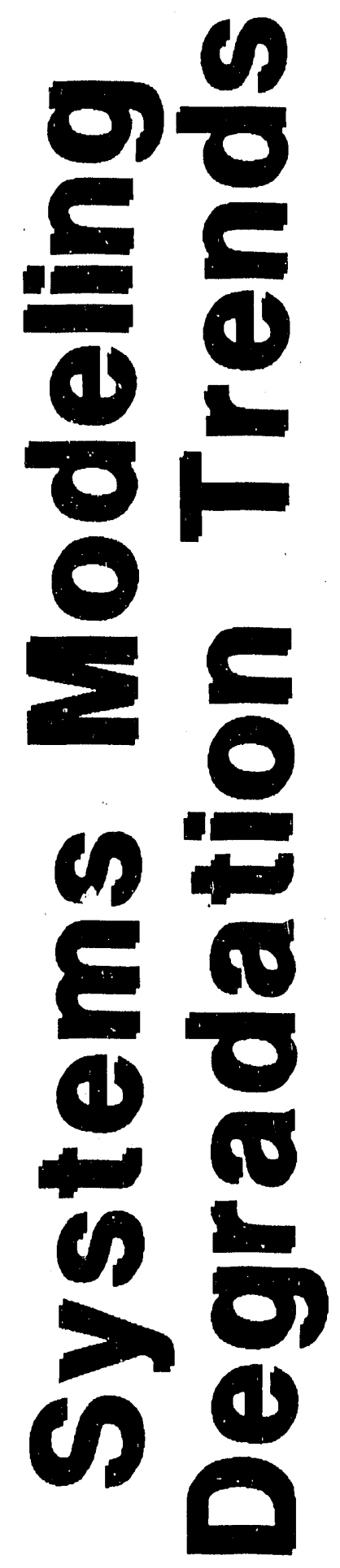

A- 23 


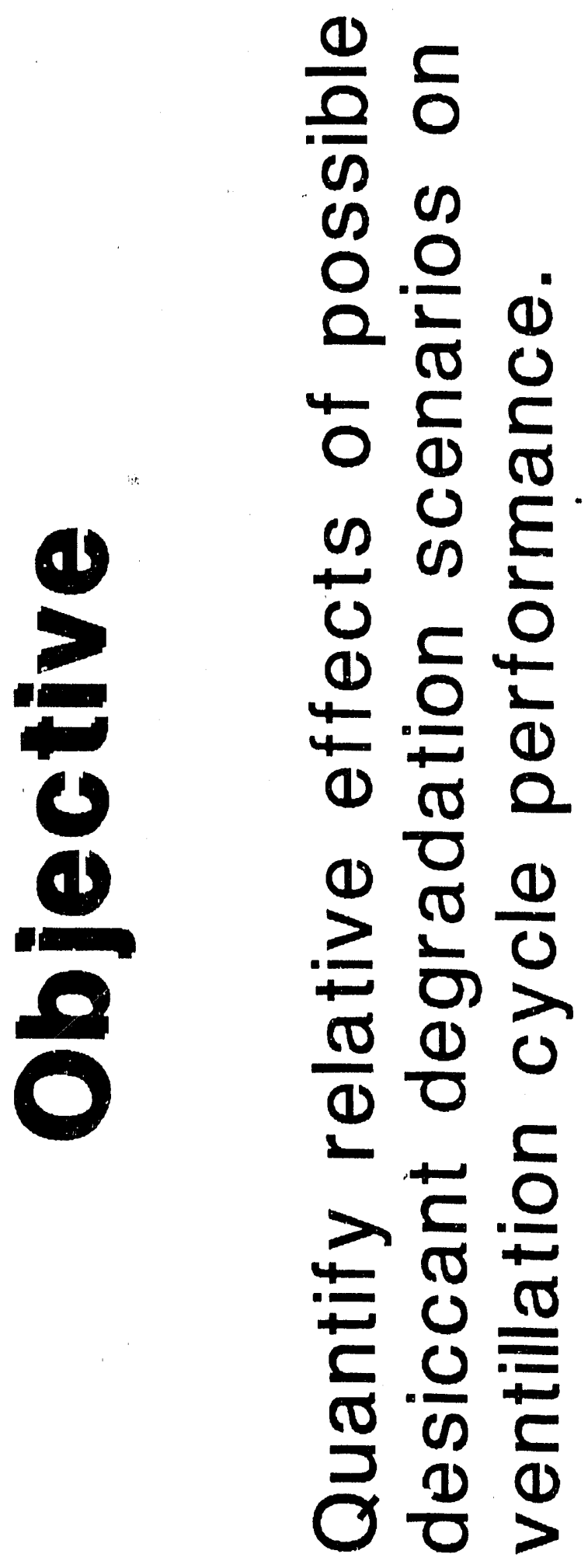




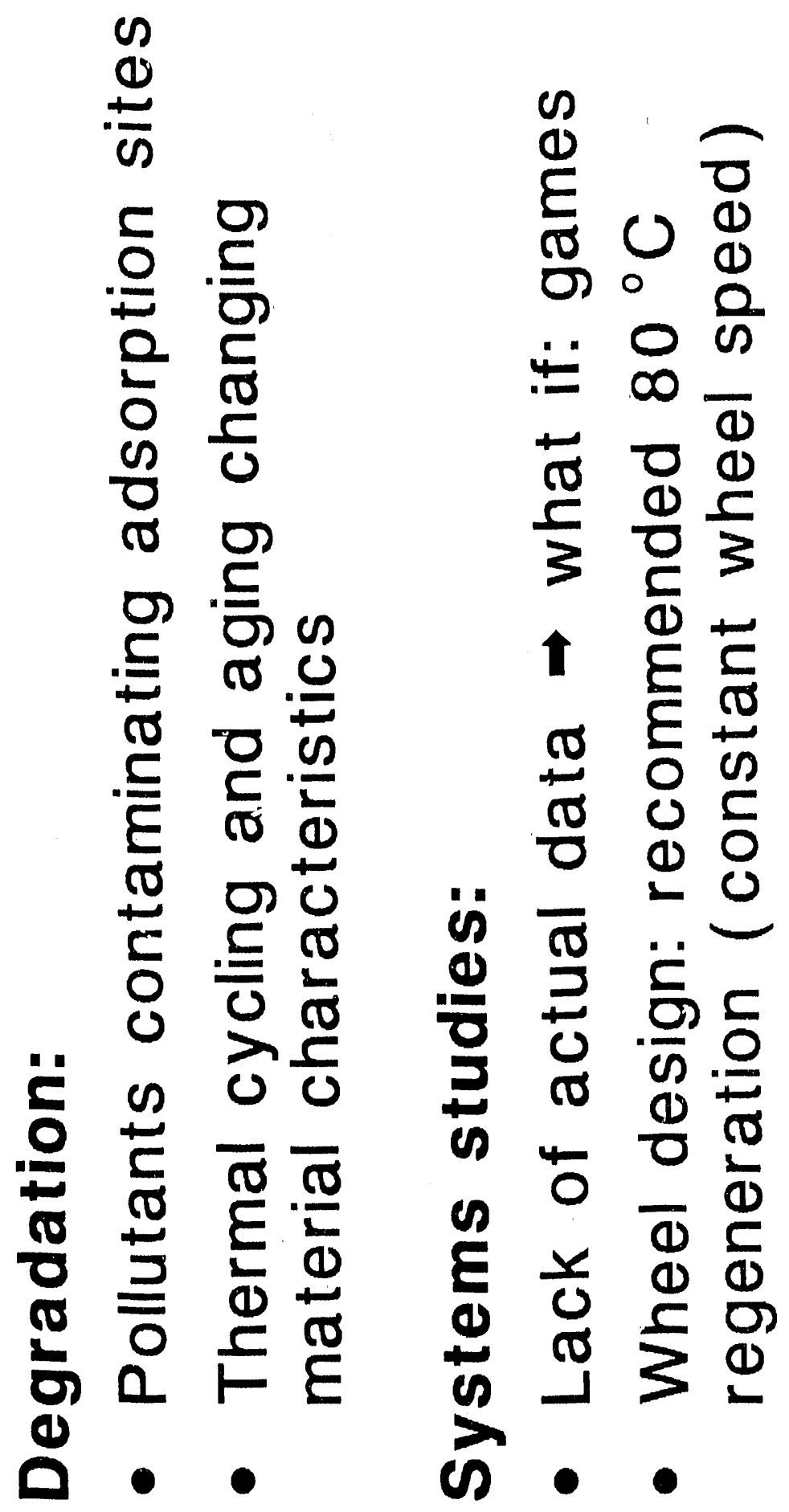




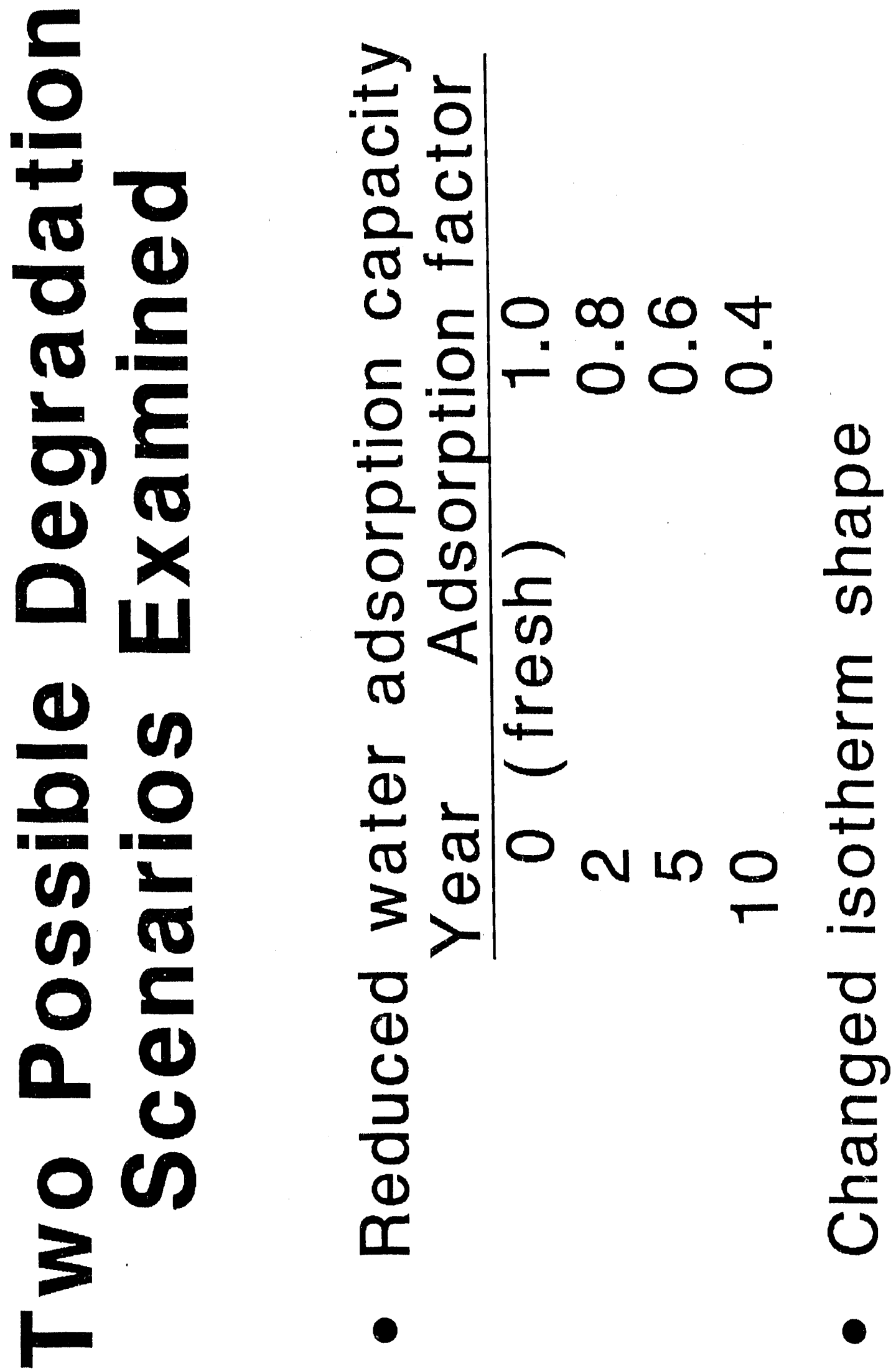




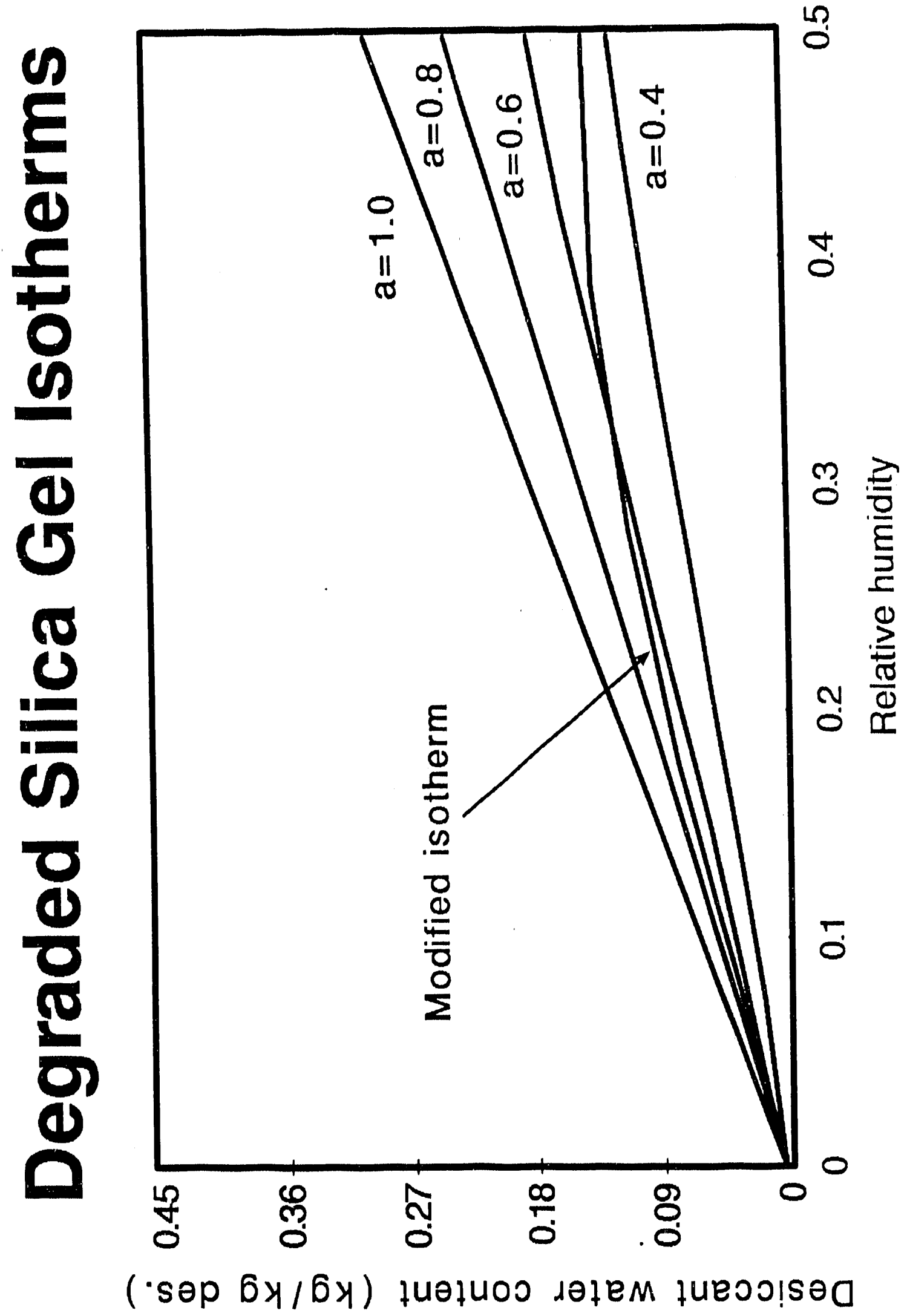




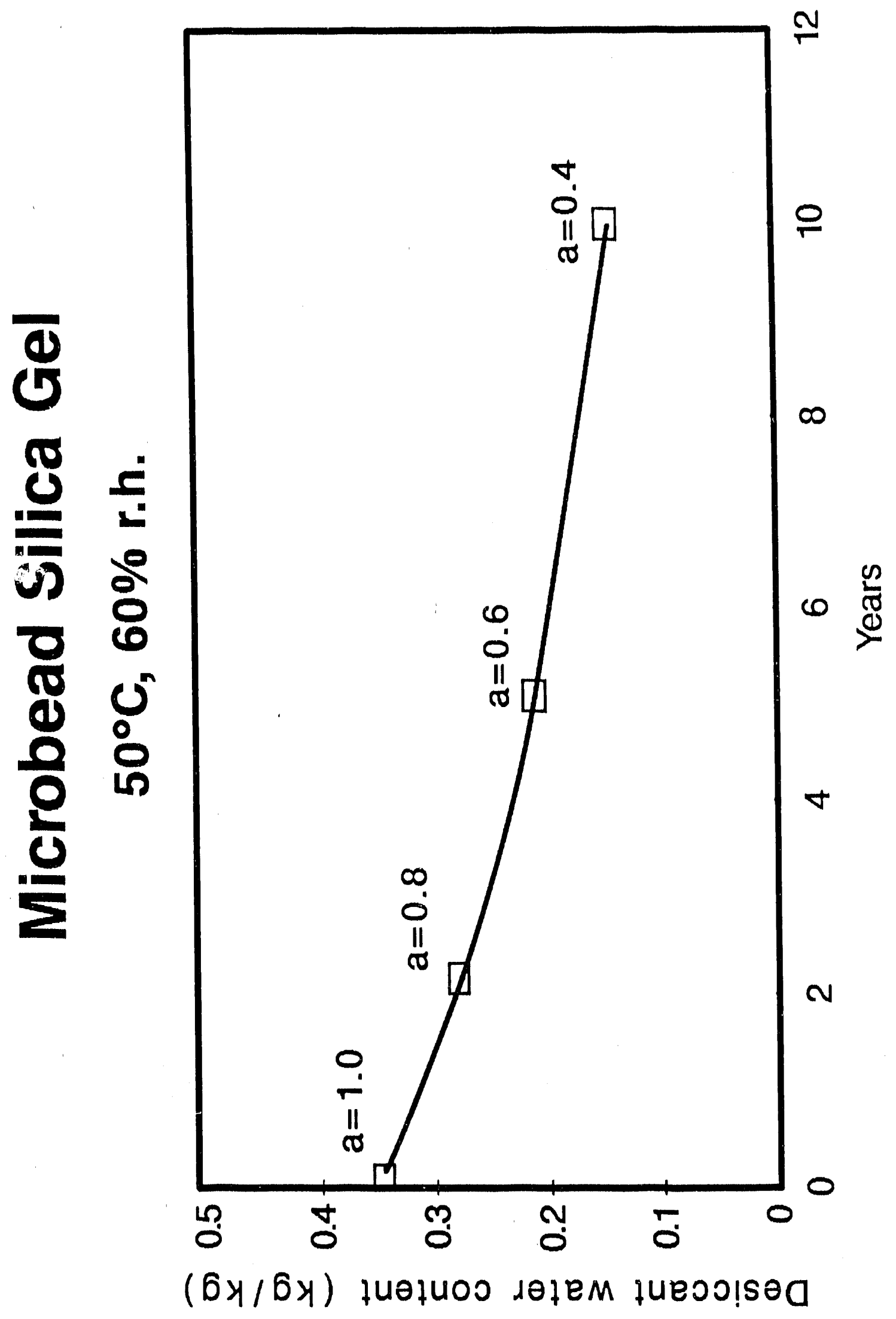




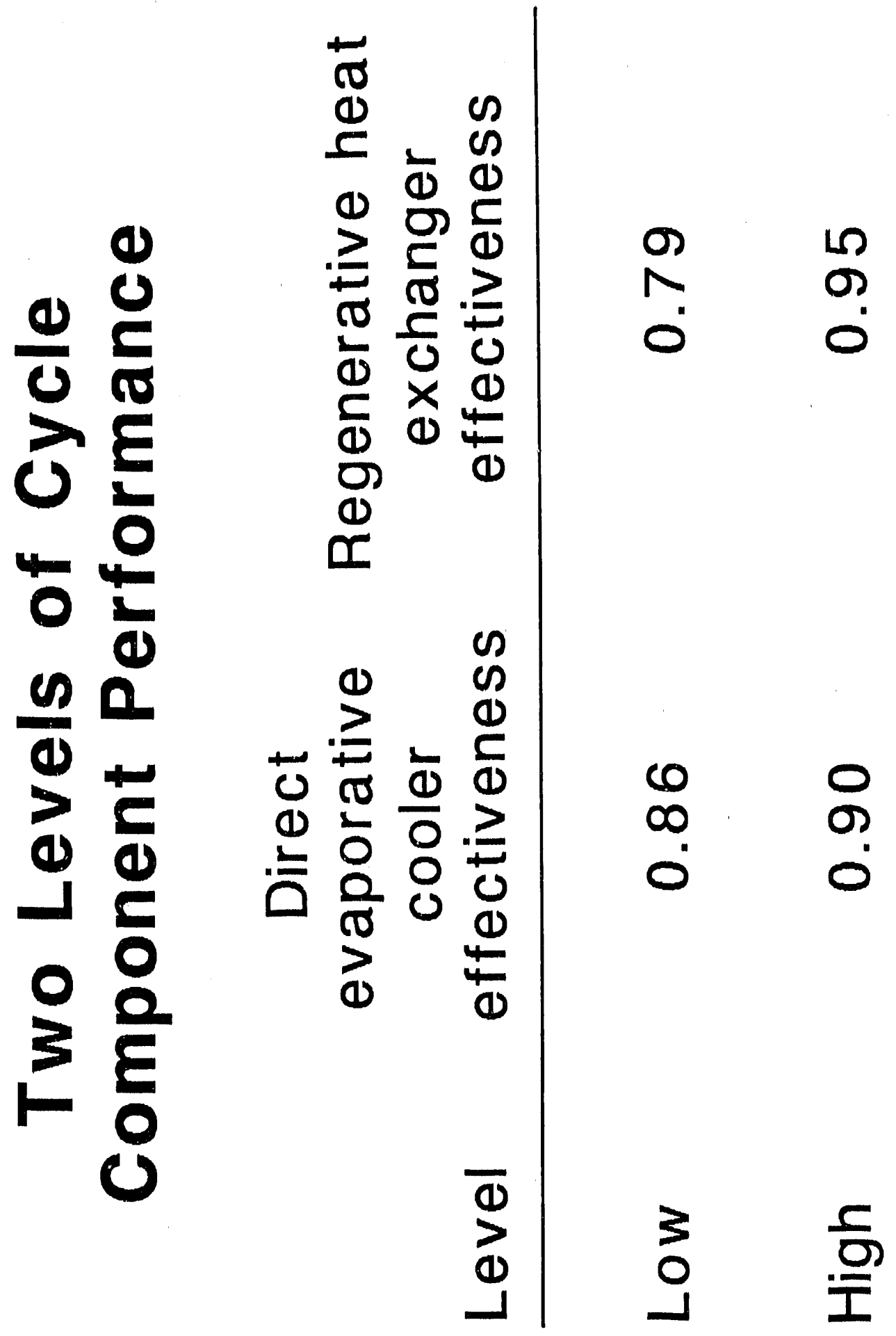




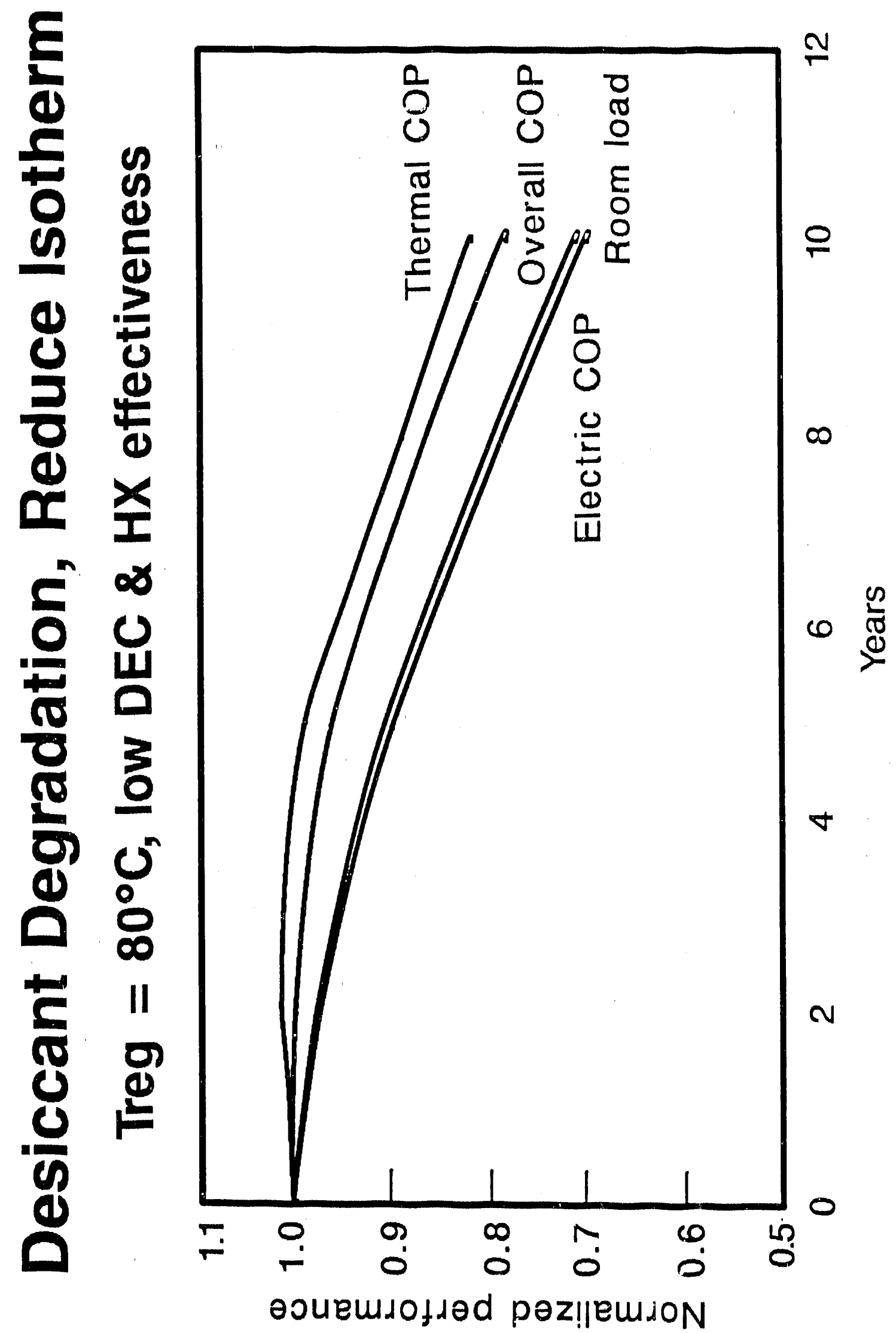




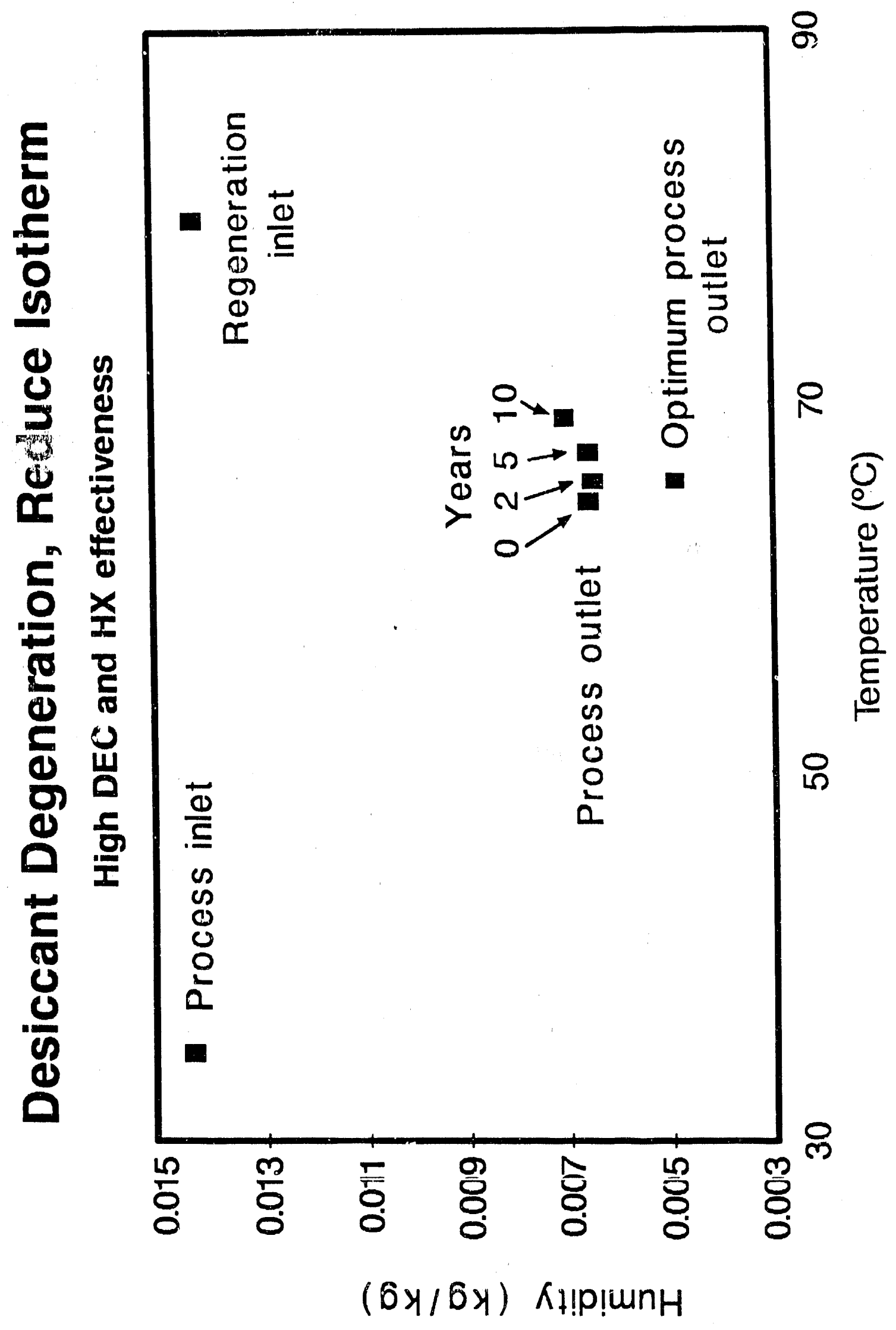




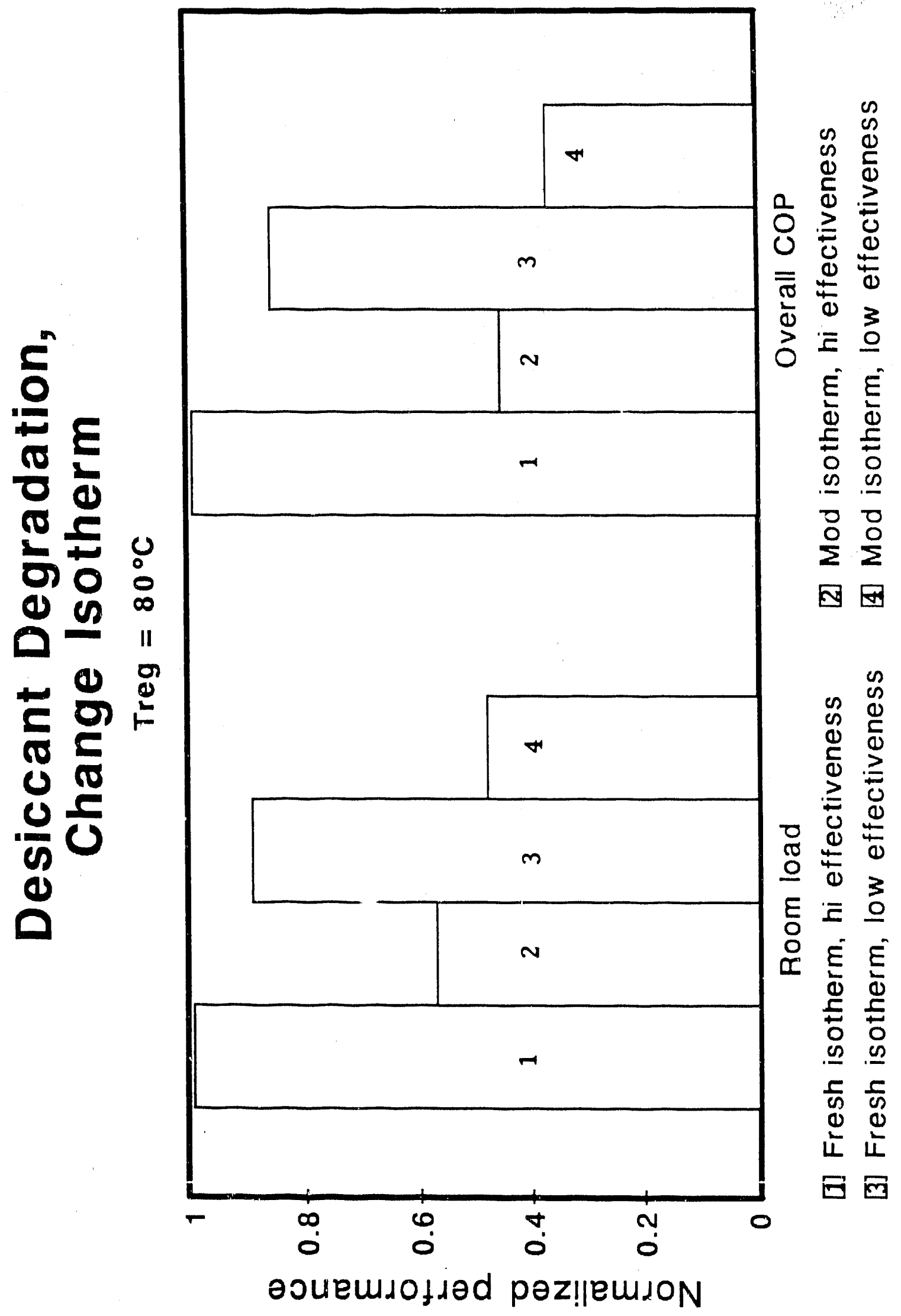




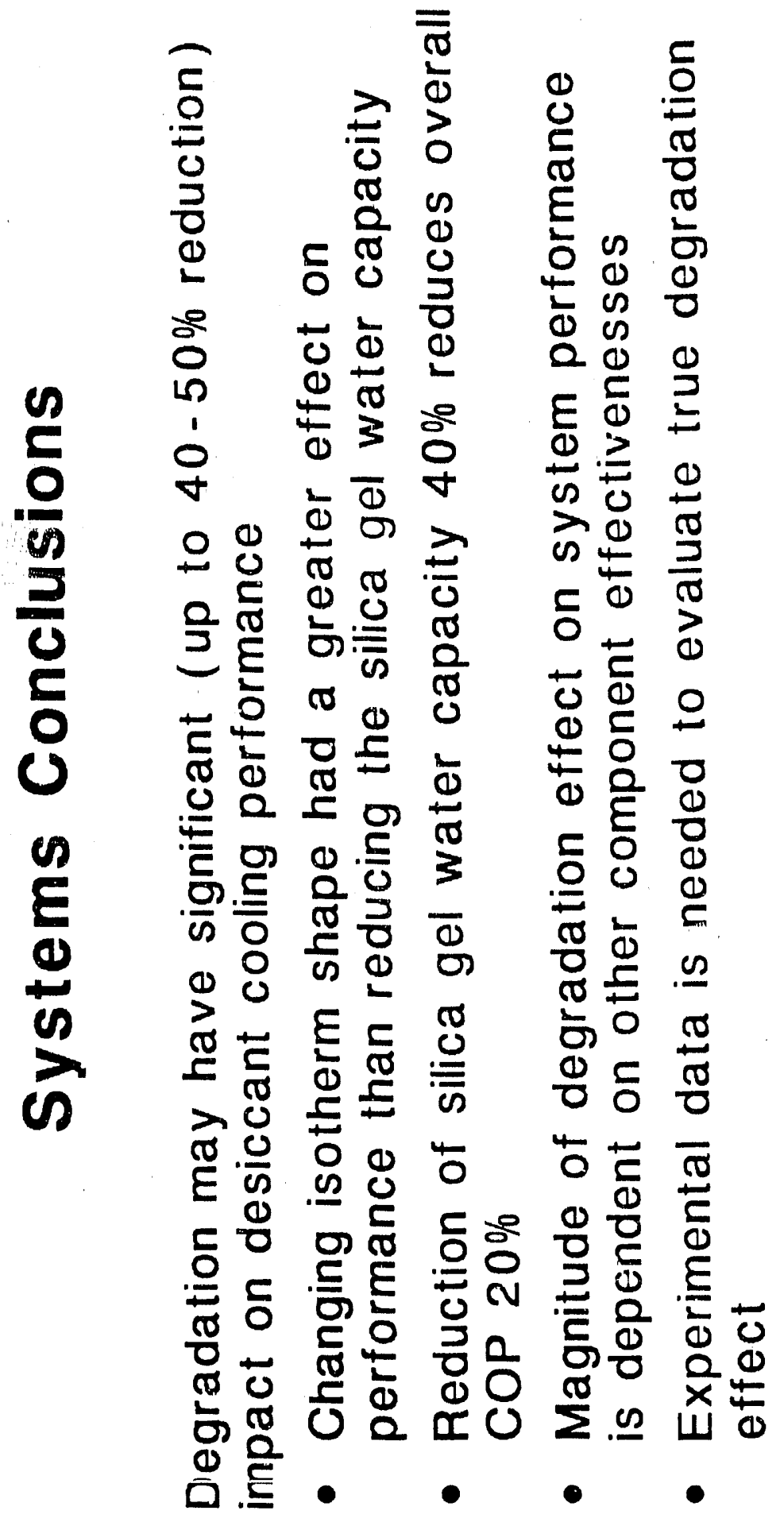


요<smiles>[O]</smiles>

\& $\infty \frac{c}{0}$

i)

$\frac{1}{\varepsilon} \pm$

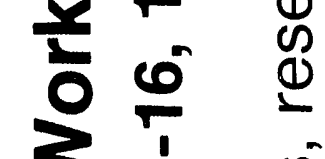

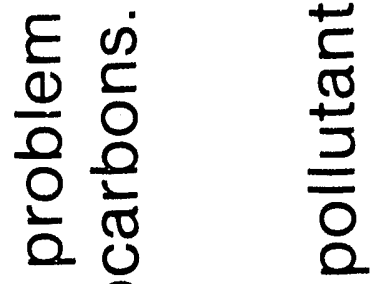

E

ช

$15 \pm$

$\varepsilon$

() 할 ह

E $0^{\circ} \frac{10}{5} \frac{0}{2}$

E 0 ह $\frac{\sigma}{\sigma}$

(1) है山

$6 \%$ iी

$0 \%$

\& E $\frac{ \pm}{\infty} \frac{\pi}{\sigma}$

$\frac{5}{\delta}$

$\frac{\sigma}{\sigma}$

원

$\pm \frac{}{\sigma}$

$\sum \frac{\pi}{\varepsilon}$

ชั

$\frac{1}{0} \stackrel{\frac{1}{5}}{\frac{1}{5}}$

क

잉 읃

I 1 in

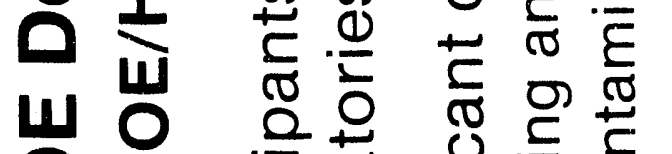

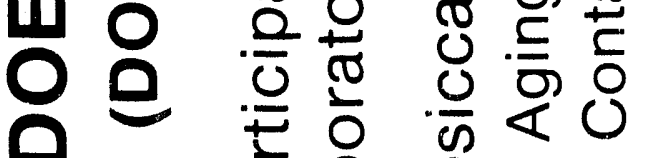

$$
\text { ฮั }
$$$$
\text { 총 }
$$$$
\text { ชర } 00
$$$$
\text { ह® ะ }
$$$$
\text { त }
$$$$
\text { झ드을 }
$$$$
\text { స ज बे ब }
$$$$
\text { I }) \text { E }
$$$$
\text { 으웜웜 }
$$$$
\text { ल U }
$$$$
\text { ० ल क }
$$$$
\text { ब T त }
$$

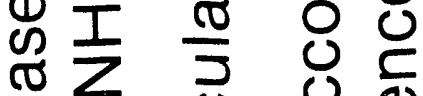$$
\text { ठ }
$$$$
\text { ֻ }
$$$$
\text { 드뇨 }
$$ 


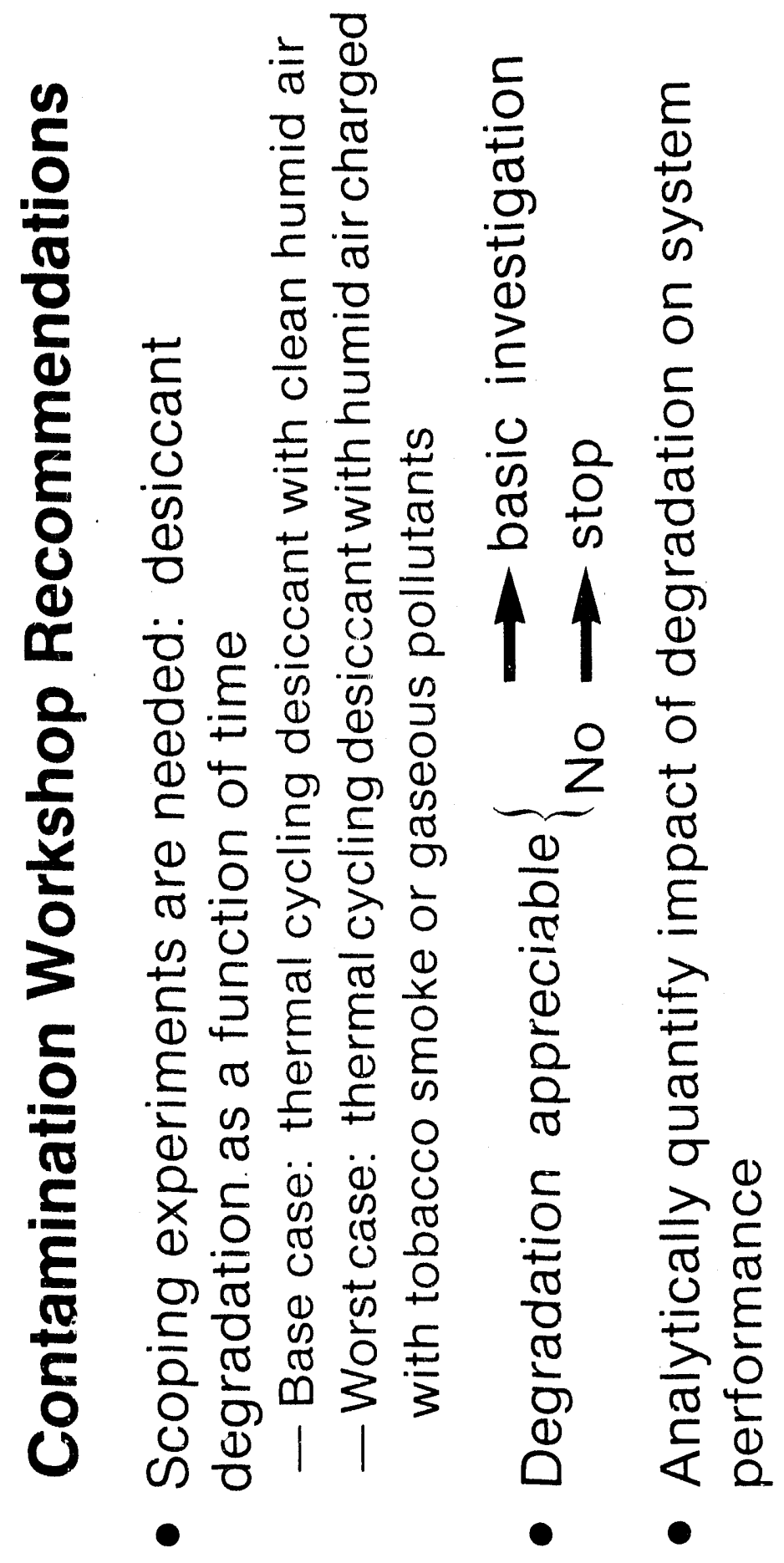




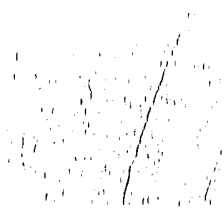

\section{Table 3 .}

Composition of Tobacco Smole: Aromatic Fraction ${ }^{\circ}$

\begin{tabular}{|c|c|}
\hline Compound & $\begin{array}{c}\text { Concentration } \\
(\mathrm{ppm})\end{array}$ \\
\hline Carbon monoxide & $42 .(K K)$ \\
\hline Carbon dioxide & $92.0 \times 1$ \\
\hline Methane, ethane, propane, butane, etc. & $87.0 \times(X)$ \\
\hline Acetylene, ethylene, propylene, eic. & $31.0 \times(x)$ \\
\hline Formaldehyde & 30 \\
\hline Acetaldehyde & $32(0)$ \\
\hline Acrolein & 150 \\
\hline Methanol & $7(x)$ \\
\hline Acelone & 1100 \\
\hline Methyl ethyl ketone & 500 \\
\hline Ammonia & $3(x)$ \\
\hline Nitrogen dioxide & 250 \\
\hline Methyl nitrite & 200 \\
\hline Hydrogen sulfide & 40 \\
\hline Hydrogen cyanide & 16000 \\
\hline Methyl chloride & 1200 \\
\hline Maior Classes & $\begin{array}{l}\text { Number of } \\
\text { Compounds }\end{array}$ \\
\hline Alkanes & $=$ \\
\hline Alkenes and alkinges & 5 \\
\hline Aromatic hycirocarbons & 96 \\
\hline Sterols and oxygenated isoprenoid compounds & 15 \\
\hline Alcohois & 24 \\
\hline Esters & $2=2$ \\
\hline Aldenydes, ketones, and quinones & 45 \\
\hline Nitriles, cyclic ethers, and sulfur compounds & 30 \\
\hline Acias & 57 \\
\hline Prenols and phenolic ethers & $\leq s$ \\
\hline Alkaloids and other bases & 107 \\
\hline Brown pigments (volatile bases and alkaloids) & 11 \\
\hline Aminc acids, proteins, related compounds & 14 \\
\hline \multicolumn{2}{|l|}{ Miscellaneous componenis } \\
\hline Inorganics & 17 \\
\hline Agriculiural chemicals (- decomposition products) & 12 \\
\hline Others & 8 \\
\hline Total & 841 \\
\hline
\end{tabular}

This fraction is usualiy ioentified by means of benzo-a-pwrene (EaP); from Siedman (1968).

From "Indoor Air Quality" by B. Meyer, 1983 p. 102 


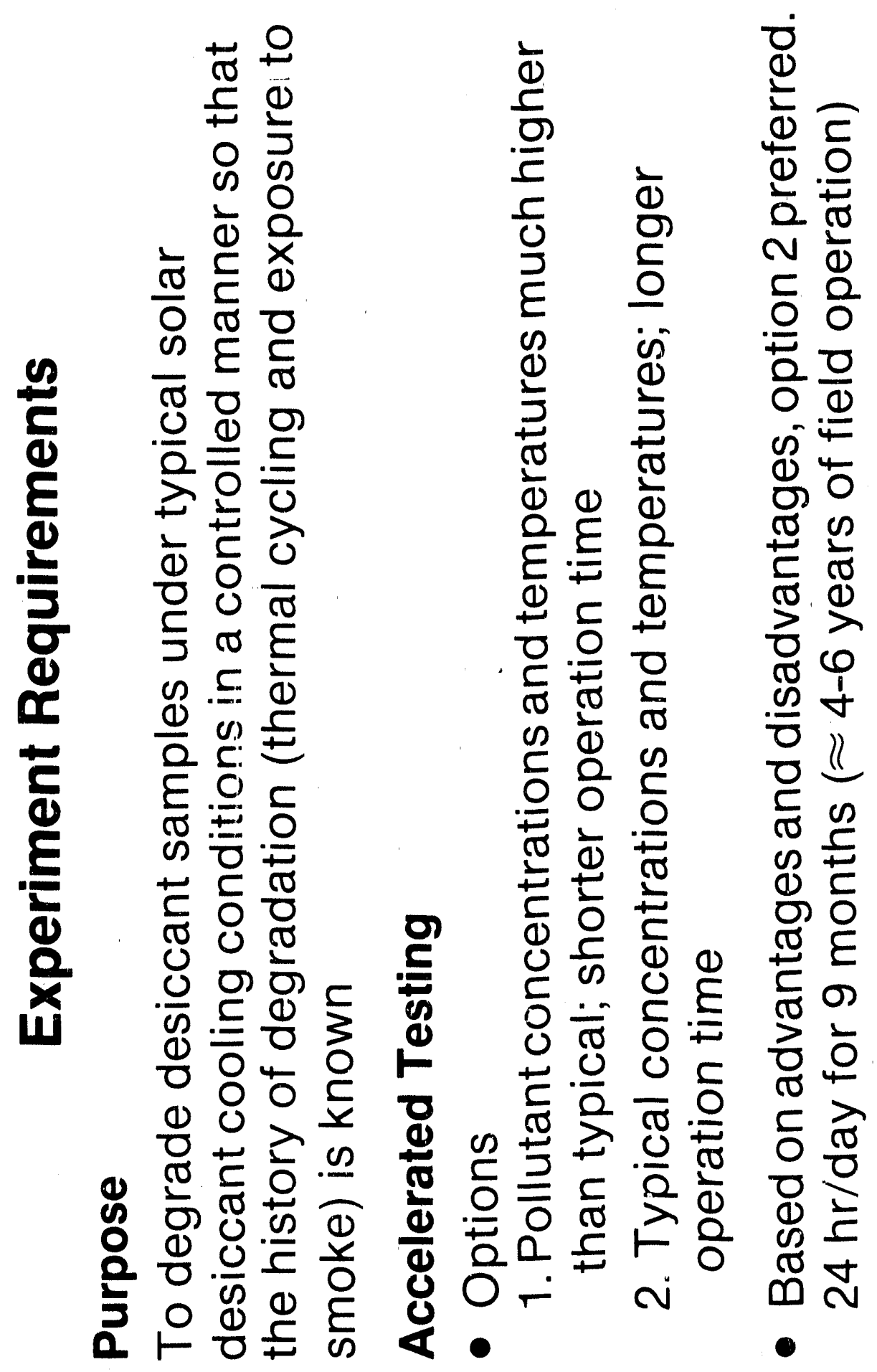




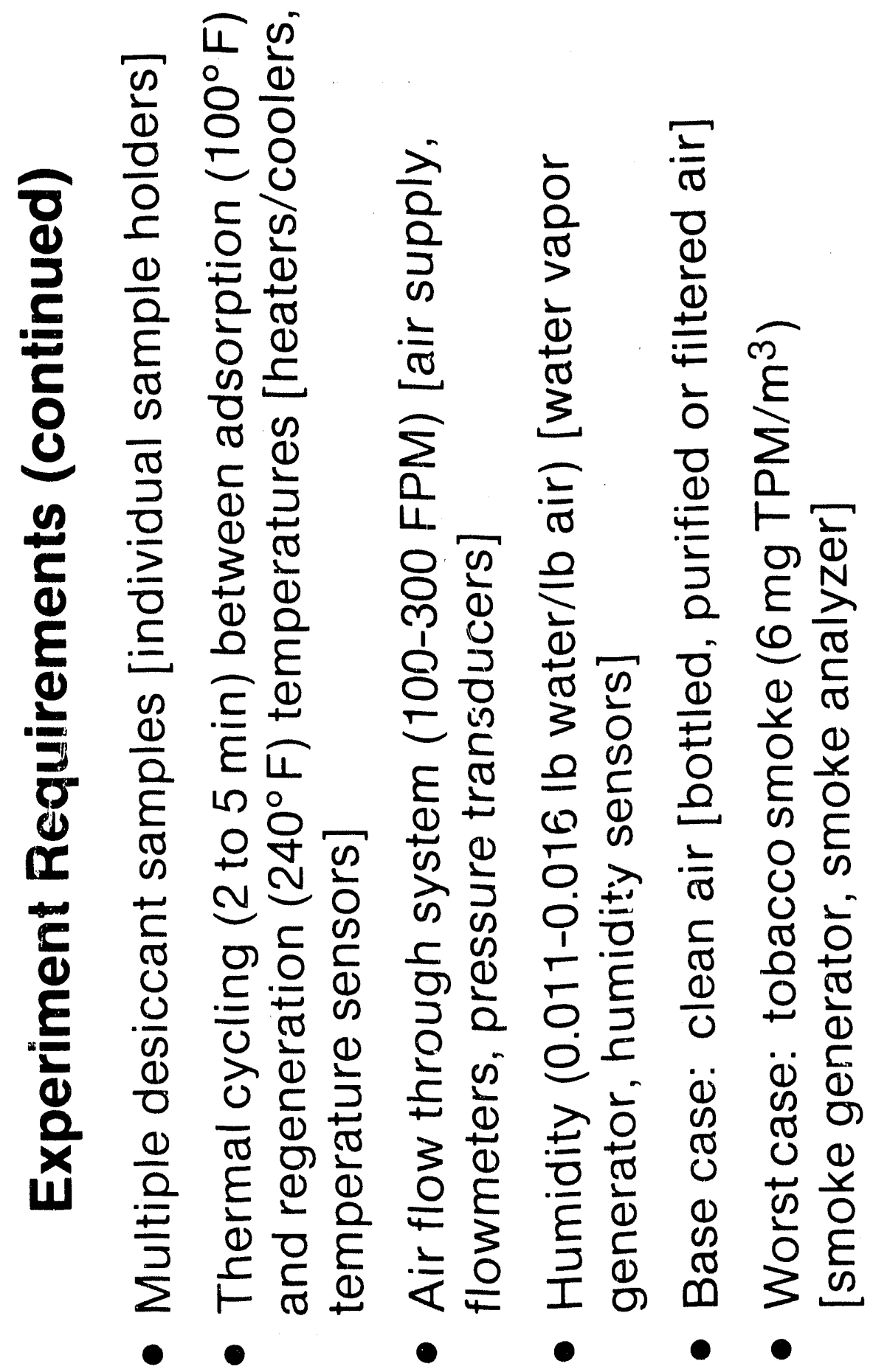




\section{Measurements of Constituents of Tobacco Smoke}

\begin{tabular}{|c|c|c|c|c|c|}
\hline Constiluem & lucalion & $\begin{array}{l}\text { Ventilation. Air } \\
\text { Clisunges Hof Hour }\end{array}$ & $\begin{array}{l}\text { Alliousli of } \\
\text { Tolidico burlled }\end{array}$ & Cuncenlraliun & Suutce ${ }^{b}$ \\
\hline \multicolumn{6}{|c|}{ Experimantal Comdiniuns } \\
\hline $\mathrm{CO}$ & $\begin{array}{l}80-170 \mathrm{~m}^{3} \text { rowins } \\
\text { Sinall car, } 25 \mathrm{~m}^{3} \text { cliamber }\end{array}$ & $\begin{array}{l}6.4-2.3 \\
\text { nume }\end{array}$ & $\begin{array}{l}46-101 \text { cifarcules } \\
4-9\end{array}$ & $\begin{array}{l}4.5-75 \mu p+11 \\
12-110 \mu p m\end{array}$ & $\begin{array}{l}1,2 \\
3,4\end{array}$ \\
\hline Nicoliric & $\begin{array}{l}57-80 \text { m }^{3} \text { rowins } \\
38-17\left(1 \mathrm{~m}^{3} \text { roums }\right.\end{array}$ & $\begin{array}{l}6.4-8.2 \\
\text { monc }\end{array}$ & $\begin{array}{l}42 \text { cigarellcs, } 9 \text { cigars } \\
\text { II/ ciparclles, } 9 \text { chuds }\end{array}$ & $\begin{array}{l}<(1.1-1) .42111 k / 11^{3} \\
0.13-1 .(14 \mathrm{111k} / 11)^{3}\end{array}$ & $\begin{array}{l}2,1,5 \\
2,5\end{array}$ \\
\hline $\begin{array}{l}\text { Tulal marliculate } \\
\text { matler }\end{array}$ & $\begin{array}{l}15-425 \mathrm{~m}^{3} \text { liwmes } \\
25 \mathrm{~m}^{3} \text { clinumber }\end{array}$ & $\begin{array}{l}1-3 \\
\text { num: }\end{array}$ & $\begin{array}{l}7-35 \text { cifiascllts } \\
4-24 \text { cifaltulls }\end{array}$ & $\begin{array}{c}1.1-3 .\left(1 \mathrm{mH} / \mathrm{m}^{3}\right. \\
2.28-166.5 \mathrm{mg} / \mathrm{m}^{3}\end{array}$ & $\begin{array}{l}6,7 \\
3\end{array}$ \\
\hline Dimethylnilrosamine & $4 \cdot \mathrm{m}^{3}$ box, $20 \mathrm{~m}^{3}$ rumm & nuns & $10-100$ cigidalles & $0.23-2.9 \mathrm{mg} / \mathrm{mn}^{3}$ & 8 \\
\hline Acroluin & $30-170 \mathrm{~m}^{3} 1 \ldots \ldots+1 \mathrm{~s}$ & nulic -2.4 & $5-150$ cigartalles & $0.02-0.20 \mathrm{ppm11.}$ & 5,9 \\
\hline Accialudihyde & $38-170 \mathrm{~m}^{3}$ rooms & nont -2.4 & $s-150$ cigarcilles & $0.106-11.56 \mathrm{ppour}$ & 5 \\
\hline Formaldehyde & $30 \mathrm{~m}^{3}$ bux & nunc & $5-10$ cigarclles & $0.23-0.46 \mathrm{p \mu n}$ & 9 \\
\hline NO & $30 m^{3}$ box & nont & $S-111$ cigartlles & $0.19-0.36 \mathrm{ppm}$ & 9 \\
\hline $\mathrm{NO}_{2}$ & $30 m^{3}$ lux & none & $5-10$ cifidelles & $0.02-11.114 \mathrm{ppm}$ & 9 \\
\hline \multicolumn{6}{|c|}{ Nalural Cundilions } \\
\hline $\mathrm{CO}$ & $\begin{array}{l}\text { Oritice, restaurant club, } \\
\text { tavern, arena } \\
\text { submarine, buat. autus, } \\
\text { bus, arplast }\end{array}$ & $\begin{array}{c}- \\
\text { none-20 }\end{array}$ & 4-150 vigarelles & $\begin{array}{l}2.5-26 \mathrm{ppm} \\
3-33 \mathrm{ppm}\end{array}$ & $\begin{array}{l}10,11,12,13,14 \\
15,16,17,18\end{array}$ \\
\hline Nicoline & $\begin{array}{l}\text { subnarinc, teimind, } \\
\text { residusans }\end{array}$ & - & 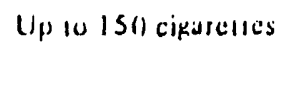 & $1-35 \mu \mathrm{g} / \mathrm{m}^{3}$ & 15,19 \\
\hline $\begin{array}{l}\text { Tolal pariculate } \\
\text { maller }\end{array}$ & Luvern, arens & $n e n c-6$ & - & $0.15-11.98 \mathrm{~m} 111 / \mathrm{m}^{3}$ & 11,12 \\
\hline Parlicites & house & - & 1 cizis & $48 \times 10^{6}$ parricites $/ \mathrm{rt}^{3}$ & 20 \\
\hline Benzupyrent & arend & - & - & $0.0(1) 71-0.0121 \mathrm{\mu g} / \mathrm{m}^{3}$ & 12,21 \\
\hline Dimcellyblnilsosidmine & bid & - & - & $0.11-(1) .24 \mu b / \mathrm{m}^{\mathrm{J}}$ & 8 \\
\hline $\begin{array}{l}\text { Kespirable parliculate } \\
\text { maller }|\mathbf{R}| \mathbf{1}\end{array}$ & $\begin{array}{l}\text { testaurants, sporls arena, } \\
\text { lowlille alley }\end{array}$ & - & - & $f U(1)-7(K) \mu \mathrm{H} / \mathrm{m}^{3}$ & 22 \\
\hline
\end{tabular}

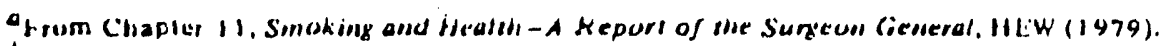

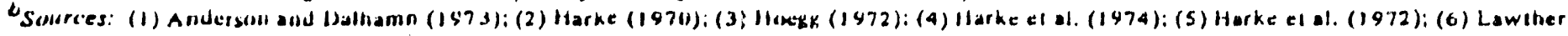

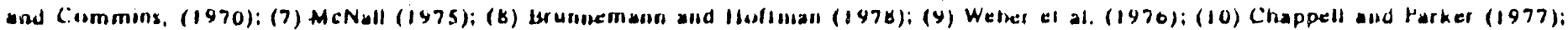

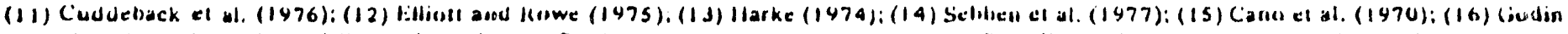

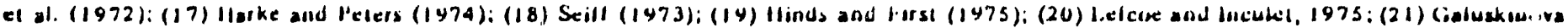
$(1964):(22)$ Repace and Lowrey (1980). 


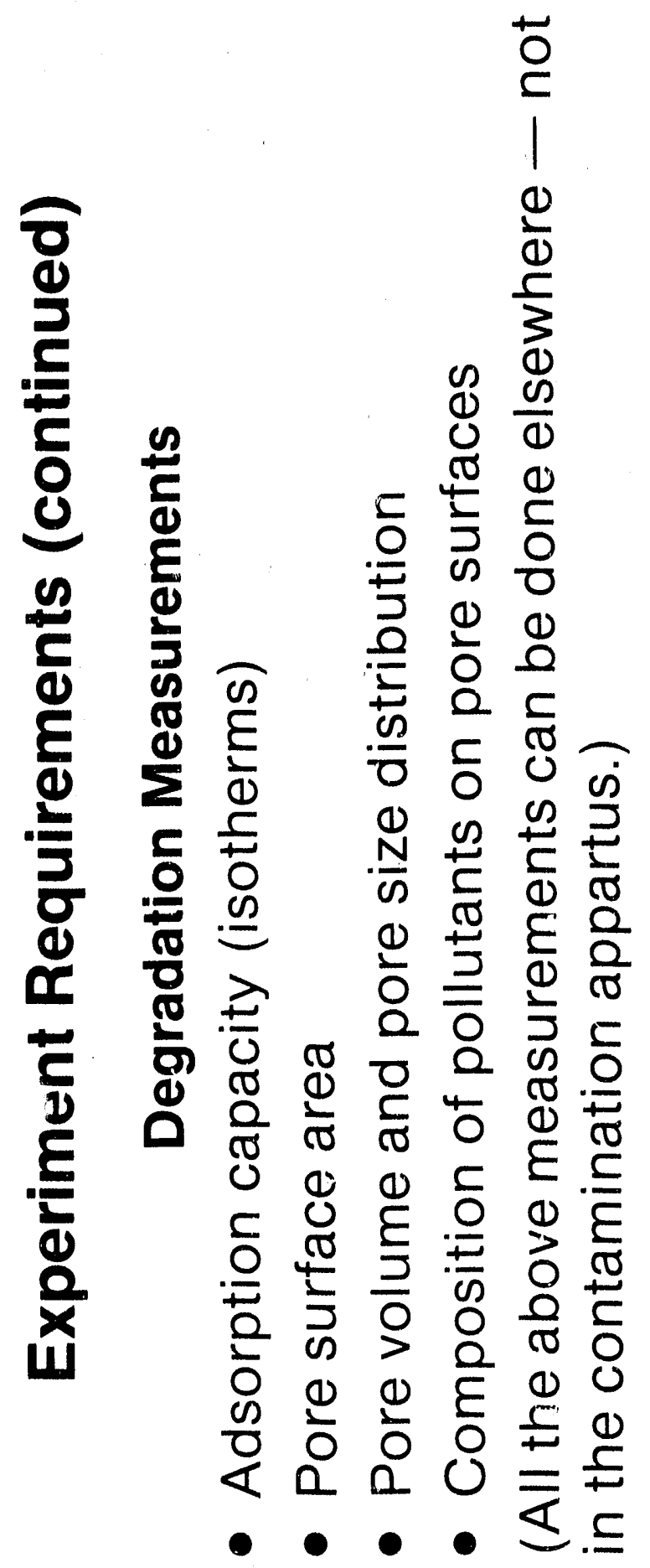




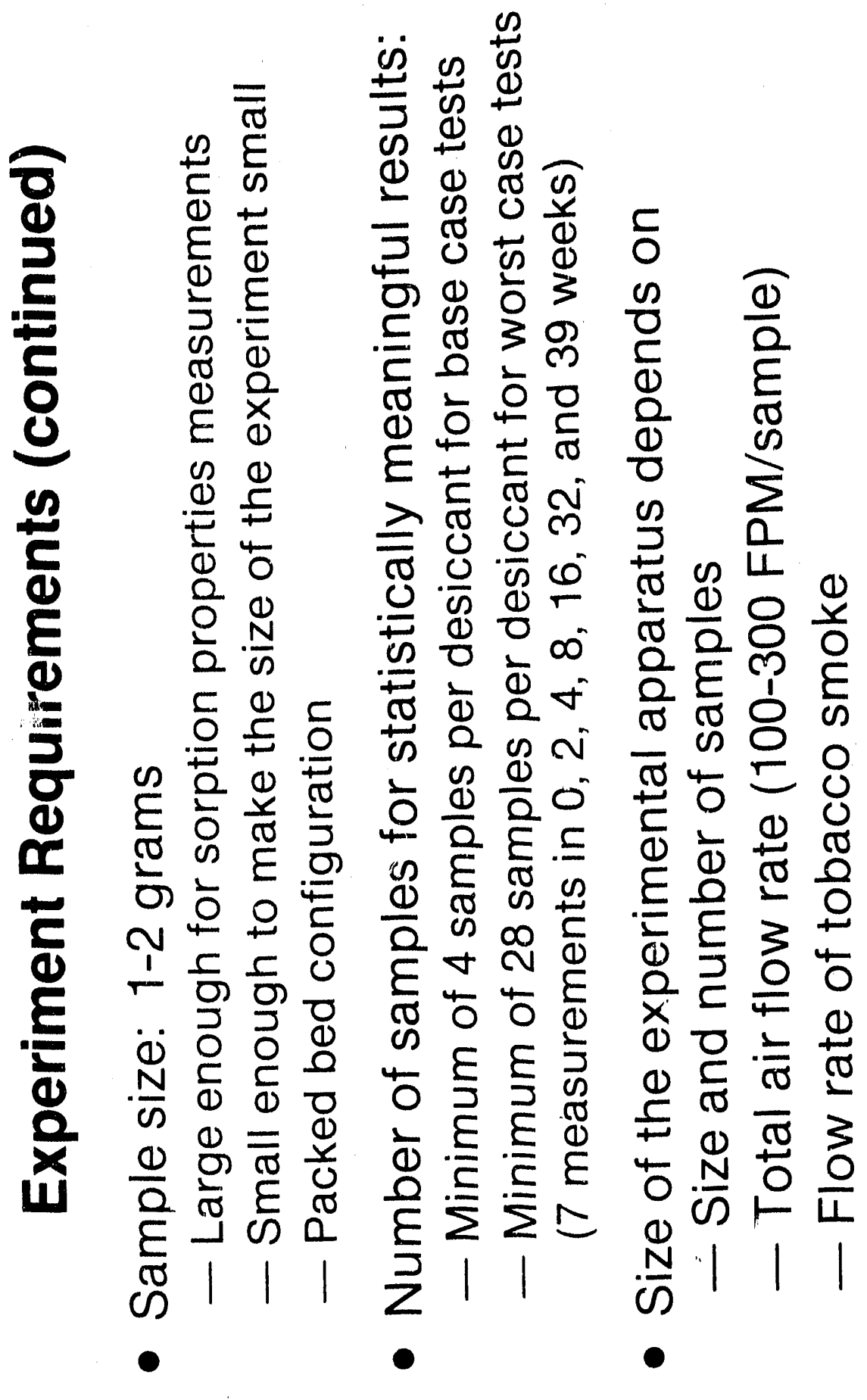


Enission Factors for Mainstream and Sidestream Smoke

\begin{tabular}{|c|c|c|c|c|}
\hline Properlies & Source ${ }^{0}$ & Mainstream & Sidestream & $\begin{array}{c}\text { Sidestream } \\
\text { Mainsirtam } \\
\text { Kallo }\end{array}$ \\
\hline \multicolumn{5}{|l|}{ General Characierislics } \\
\hline Duralion of smoke produciion & $?$ & $20 \mathrm{sec}$ & $590 \mathrm{sec}$ & 27 \\
\hline Amouni of lobacco burni & $?$ & $347 \mathrm{mt}$ & $411 \mathrm{mg}$ & 1.2 \\
\hline Numbel of particles per cifarcule & 2 & $1.05 \times 10^{12}$ & $5 \leq \times 10^{15}=$ & 3.3 \\
\hline Particie number median diameles & 2 & $0.2 \mu \mathrm{m}$ & $0.15 \mu \mathrm{m}$ & 0.75 \\
\hline Porlucularc Phase & & $\mu g / c i p a r c i l c$ & uf/ciparelle & \\
\hline Total suspended particulale maller & 2 & 36.200 & 25.800 & 0.7 \\
\hline Tar (chloroform exiract) & 9.2 & $<5011-29,000$ & 44.100 & $\therefore .1$ \\
\hline Nicotine & 4,9 & $10(-2500$ & $27001-6750$ & $\therefore 7$ \\
\hline Total phenols & 2 & 228 & 603 & 2.6 \\
\hline Pyrene & 4 & $56,-200$ & $18(1-420$ & 3.6 \\
\hline Benzola)pyrent & 4 & $2(1-40$ & $68-136$ & $3 .:$ \\
\hline Naphithalene & 4 & 2.6 & 40 & 16 \\
\hline Methyinaphthalene & 4 & 2.2 & 60 & 28 \\
\hline Aniline & 2 & 0.36 & 10.8 & 30 \\
\hline NNN & 4 & $0.1-0.55$ & $0.5-2.5$ & 5 \\
\hline NNK' & 4 & $0.08-0.22$ & $0.8-. .2$ & 10 \\
\hline Codmium & 2 & 0.13 & 0.45 & 3.6 \\
\hline Nickel & 3 & 0.08 & - & - \\
\hline Arsense & 3 & 0.012 & - & - \\
\hline 2-Napinthyiamune & 2 & $0.00=-0.028$ & 0.08 & 30 \\
\hline Hyorogen cyaniae & $s$ & 74 & - & - \\
\hline Poionium.210 & $i$ & $\begin{array}{l}0.025-0.044 \\
0 \text { Di/cipaserre }\end{array}$ & - & - \\
\hline Gases ano' Vadors & & HEicifaretse & uglcigarente & \\
\hline Carbon monoxioe & 4.9 & $1000-20.000$ & $25.006-\$ 0.000$ & $a s$ \\
\hline Carbon dioxidet & 4 & $20.00(1-60.000$ & $160.006-480.000$ & E.1 \\
\hline Acetaldenyoe & 1,3 & $18-1400$ & $\Delta 6 \cdot-\$ 100$ & $\therefore c^{\prime}$ \\
\hline Hydropen cyanioe & 4 & 430 & 110 & 0.75 \\
\hline Methylchiorioe & 4 & 650 & $: .300$ & 2.1 \\
\hline Acelont & 4 & $100-600$ & $2501-1500$ & 9.8 \\
\hline Ammoniz & $1,5,2$ & $10-150$ & $9801-150,000$ & 98 \\
\hline Pyridine & ¿.3.4 & $5-9$ & $9(1-530$ & 10 \\
\hline Acrolein & 1,3 & $25-140$ & $\leq 2-300$ &. .20 \\
\hline Nituic oxide & 3.6 .8 & $16-570$ & $2300^{e}$ & $\leq$ \\
\hline Nisuogen dioxide & $3,6,8$ & $0.5-30$ & $62: 5$ & 20 \\
\hline Formaldenyde & $\vdots 6$ & $2(1-90$ & 1300 & 15 \\
\hline DMN' & $\therefore$ & $1(1-65$ & $5201-3380$ & $\leq 9$ \\
\hline NFy & 4 & $10-35$ & $27(1-045$ & 97 \\
\hline
\end{tabular}

'Sources: (1) Wakenam (1972): (2) Hoegf (19:2): (3) HEH' 1979, Chap. 14:14) HEW' (1979). Chaf. 11: (5) Schmeliz et al. (1975); (6) Weber et al. (1979); (7) Kelley (1965); (8) Jenkıns and Gill (1980): (9) FTC (1981).

NNirrosonornicoune (NNN).

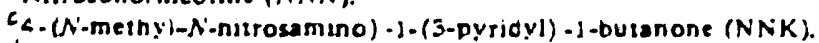

$C_{\text {Katioed from total aldenydes. }}$

e Eased on the dals of Webet el al. $(1479)$, Tabla 1 , assuming a mixis, factor of 2.0 . Values will be lowe: if mixivig was less inan ideal.

i Dimetnyinurrosamine (DMN).

S Nirrosopyralidine (NPy).

From "Indoor Air Pollution" by liadden and Scheff, 1983, p. 59 


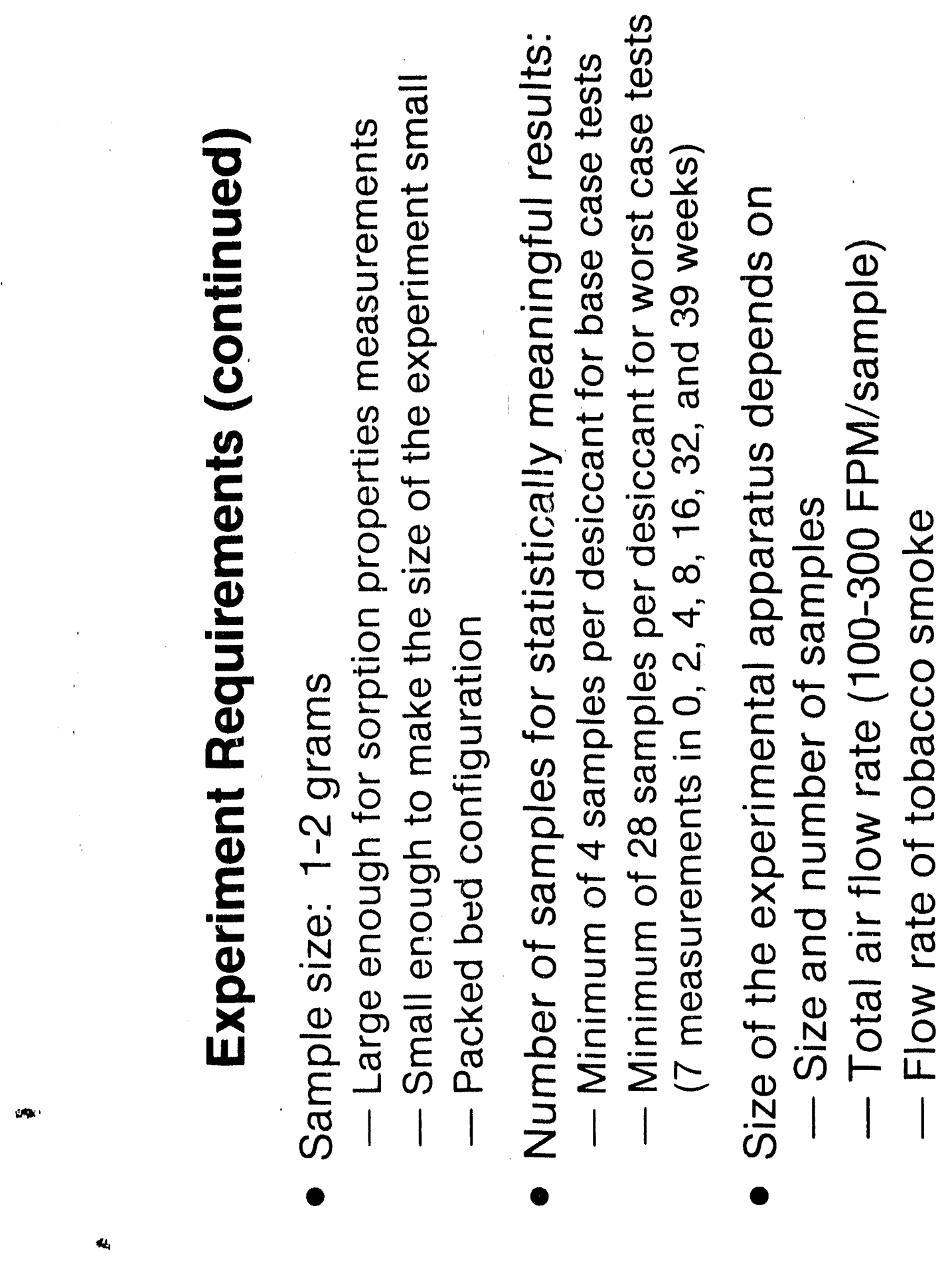


Enission Factors for lainstream and Sidestream Smoke

\begin{tabular}{|c|c|c|c|c|}
\hline Properilies & Source & Manstream & Sidesiream & $\begin{array}{c}\text { Sioesireami } \\
\text { Mainsistam } \\
\text { Kalio }\end{array}$ \\
\hline \multicolumn{5}{|l|}{ Generol Characierisilics } \\
\hline Duration of smoke production & 2 & $20 \mathrm{sec}$ & 5.50 sec & 27 \\
\hline Amouni of lobacco burnt & $?$ & $347 \mathrm{mg}$ & $411 \mathrm{mf}$ & 1.2 \\
\hline Nurnbel of particles per cifarelle & 2 & $1.0 \leq \times 10^{12}$ & $3.5 \times 11^{15}=$ & $3 . .3$ \\
\hline Particle number median diameies & 2 & $0.2 \mu \mathrm{m}$ & $0.15 \mathrm{\mu m}$ & 0.75 \\
\hline Porticuloic Phase & & MF/ciparelic & uF/cifarelle & \\
\hline Total suspended particulate matter & 2 & 36.200 & 25.800 & 0.7 \\
\hline Tas (chloraform extraci) & 9.2 & $<50(1-29.000$ & 44.100 & 2.1 \\
\hline Nicorine & 4,9 & $101-2500$ & $2700-6750$ & $\therefore .7$ \\
\hline Toral phenols & 2 & 228 & 603 & $\therefore 6$ \\
\hline Pyisene & 4 & $56-200$ & $18(1-420$ & 3.6 \\
\hline Benzola)pyrene & 4 & $2(1-40$ & $68-136$ & 3.2 \\
\hline Naphthalene & 4 & 2.8 & 40 & 16 \\
\hline Methylnaphinalese & 4 & 2.2 & 60 & 28 \\
\hline Aniline & 2 & 0.36 & 10.6 & 30 \\
\hline NNN'D & 4 & $0.1-0.55$ & $0.5-2.5$ & 5 \\
\hline NNK'C & 4 & $0.08-0.22$ & $0.8-. .2$ & 10 \\
\hline Coomium & $?$ & 0.13 & 0.45 & 3.6 \\
\hline Nickel & 3 & 0.08 & - & - \\
\hline A:senis & $\vdots$ & 0.012 & - & - \\
\hline 2-Napinthyiamine & 2 & $0.00=-0.02 \varepsilon$ & 0.08 & 30 \\
\hline Hydroger cyanioe & $\leq$ & 74 & - & - \\
\hline Pojonium.210 & i & $\begin{array}{l}0.026-0.024 \\
\text { pci/cicaseite }\end{array}$ & - & - \\
\hline Goses ond Vapors & & mEicsparelle & ug̣icifaretre & \\
\hline Carbon monoxioe & 4,9 & $1006 .-20.000$ & $=5.000(1-50.000$ & 2.5 \\
\hline Carbon dioxioe & 4 & $20.00(-60.000$ & $160.000 .-480.000$ & 6.1 \\
\hline Aceraldenyoe & 1,3 & $18-i+00$ & $4(-3100$ & $\therefore .2 c$ \\
\hline Hyarogen eyanioe & 4 & 430 & 110 & C.IS \\
\hline Merhylchlorioe & 4 & $6 \leq 0$ & $\therefore .300$ & $=.1$ \\
\hline Aceiont & 4 & 100.600 & $2501-1500$ & 3.5 \\
\hline Ammoniz & $1,3,2$ & $10-150$ & $98(1-150,000$ & 98 \\
\hline Fyridine & ¿.3.4 & $c-c j$ & $90 .-530$ & 10 \\
\hline Acroiesn & 1,3 & $24-140$ & $\therefore-300$ & $3.2{ }^{2}$ \\
\hline Niuric oxide & \pm .6 .8 & $10 .-570$ & $230 c^{e}$ & 4 \\
\hline Nitrogen dioxide & -6.8 & $(1.3-30$ & Ease & 20 \\
\hline Formaldenyde & $\vdots 6$ & $2(1-90$ & 1300 & 15 \\
\hline DMNf & 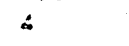 & $11-65$ & $\leq 26-\Xi 380$ & $\leq 2$ \\
\hline NFyt & 4 & $10-35$ & $27(1-0,45$ & 27 \\
\hline
\end{tabular}

'Sources: (1) Wakenam (19?2): (2) Hoesf (19:2): (3) HEW' 1979, ChaE. 14:(4) HEW' (1979), Chap. 11: (5) Senmeliz et al (1975); (6) wever et as. (1979): (7) kelley (1965): (8) Jenkins and Gill (1980): (9) FTC (1981).

ENitrosonomicotine (NNN).

Cs-(N'-metnyi-N-nurosamino) - 1-(j-pyrioyl) - - -butanone (NNK).

Ckatioed from ioial aloehyoes.

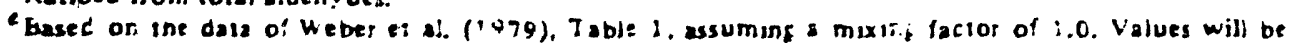
lowe: if mixinf was leas inan ioteal.

J Dimeinyinirrosumine (DMN).

S Nirtosopyrolidine (NPy).

From "Indoor Air Pullution" by Wadden and Scheff, 1983, p. 59 


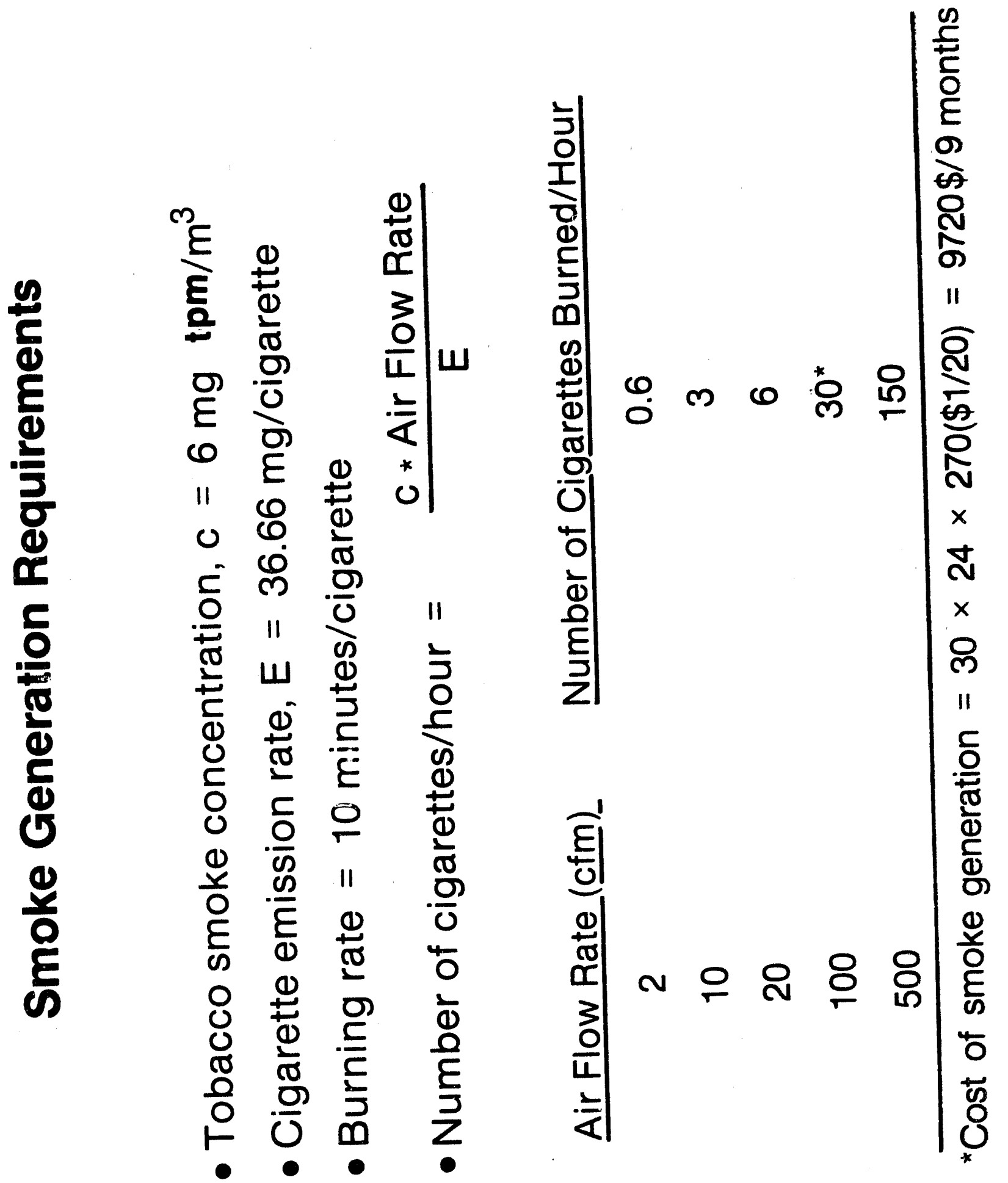




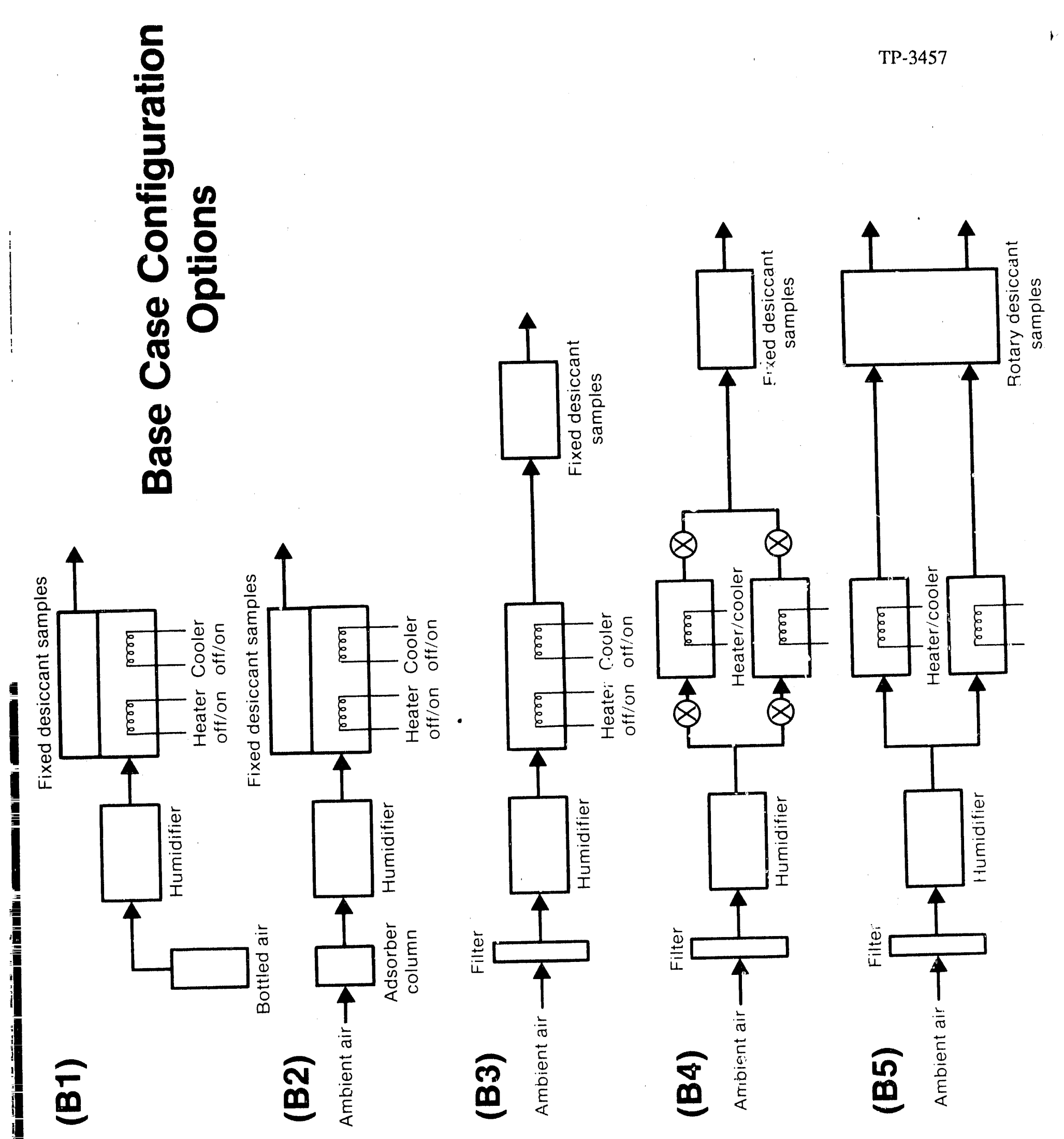



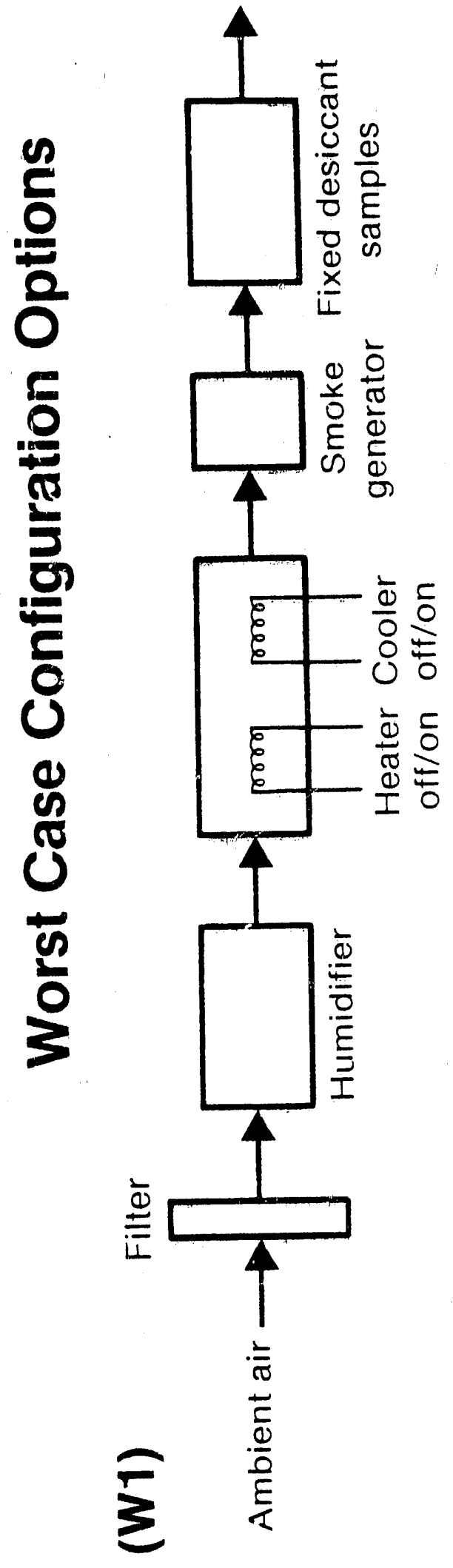

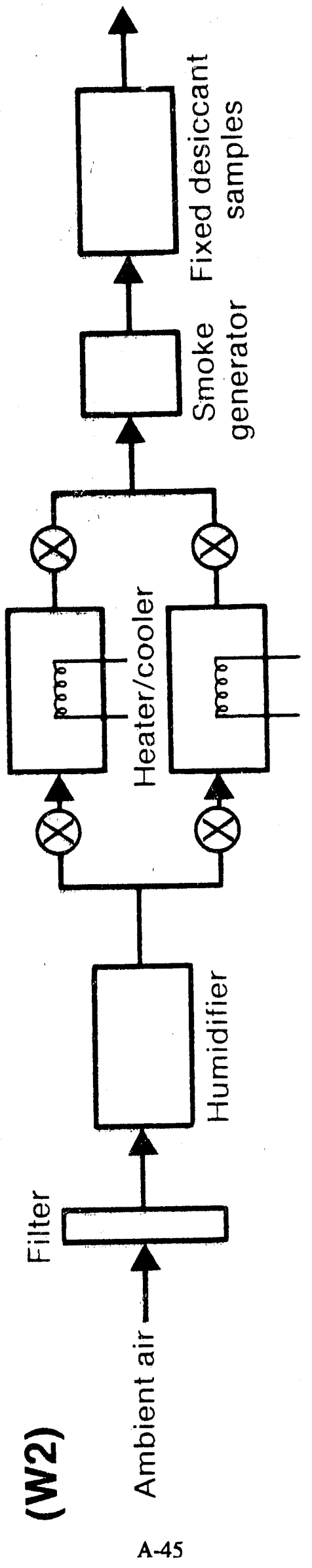

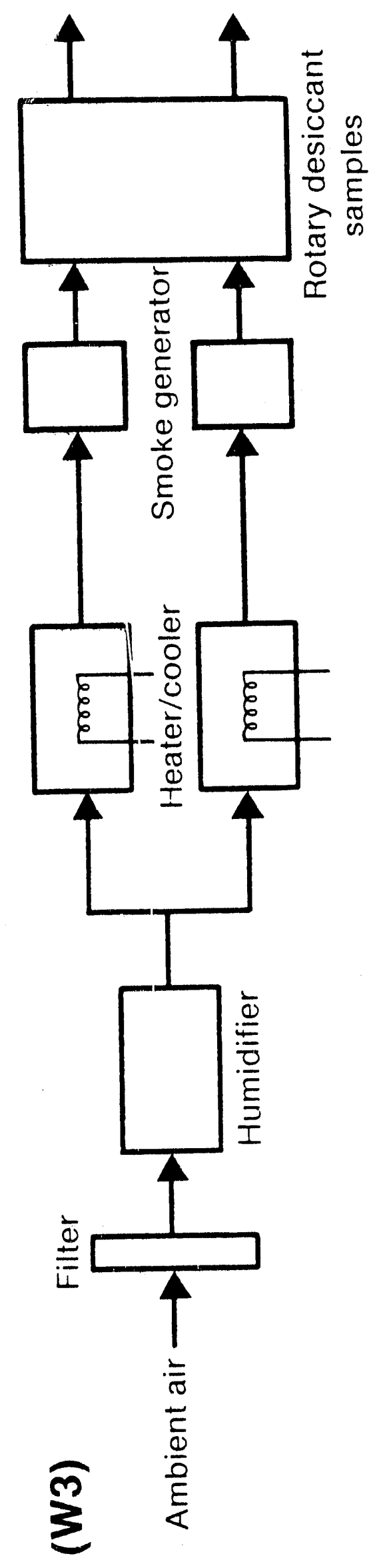




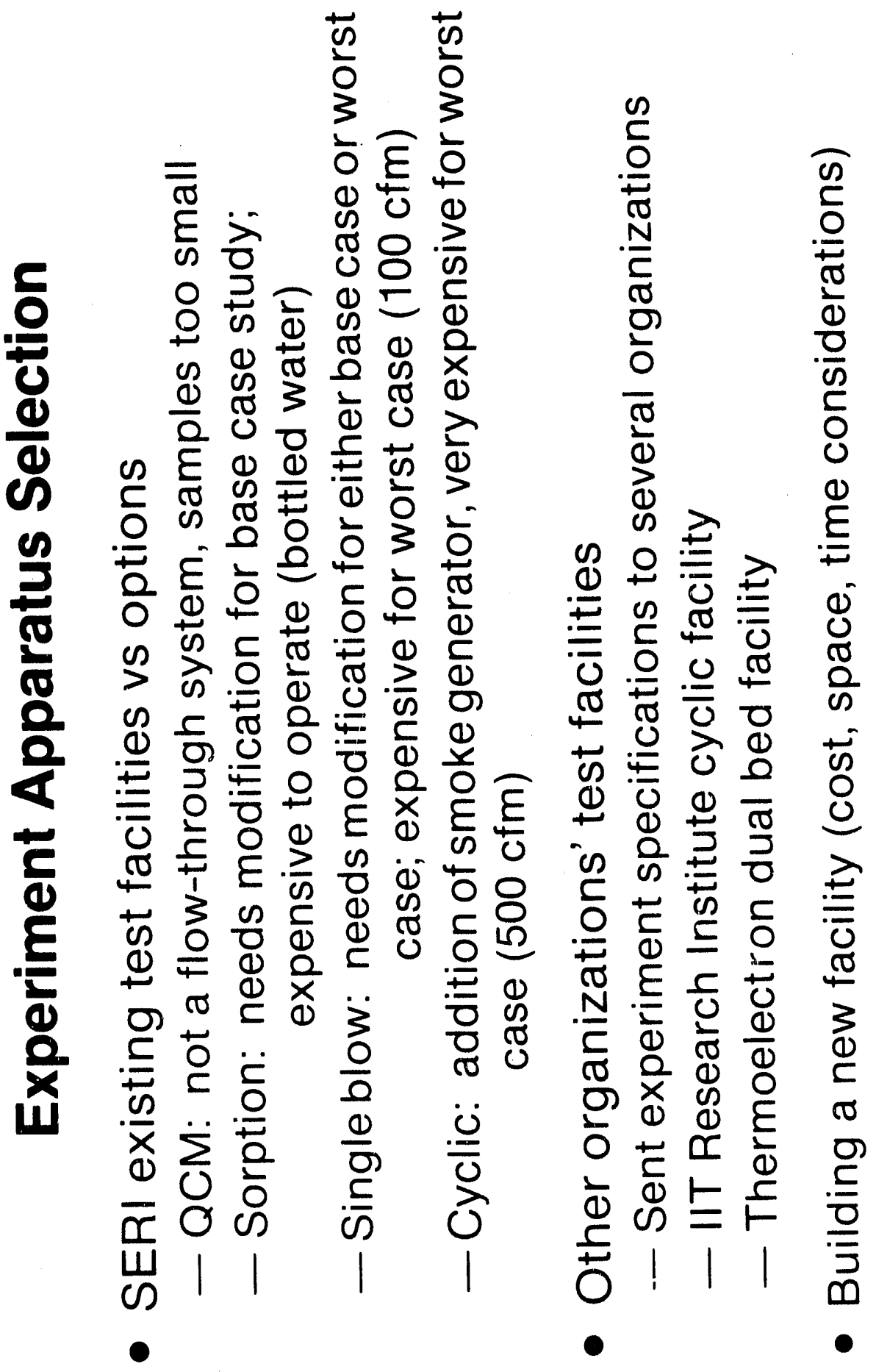




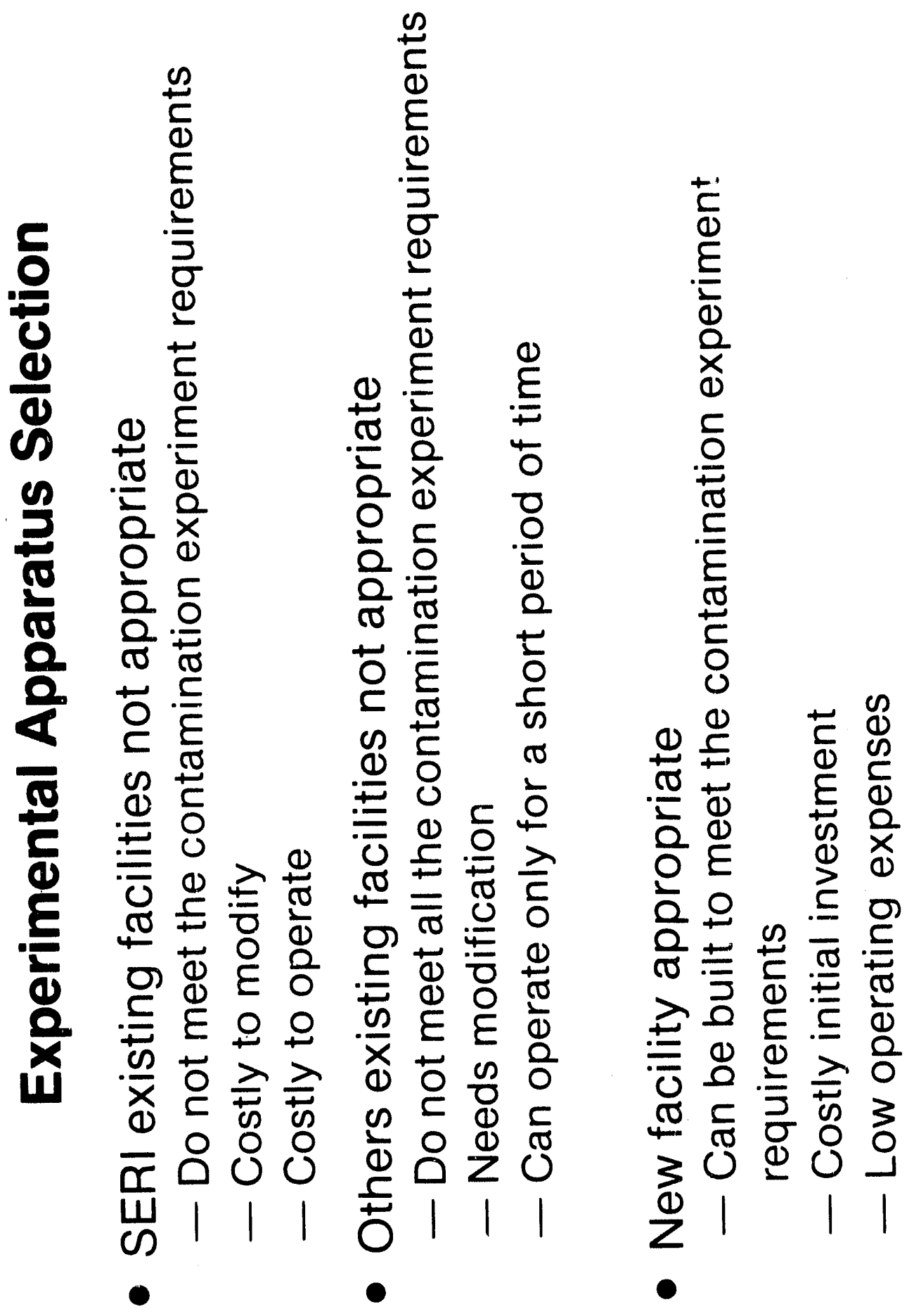




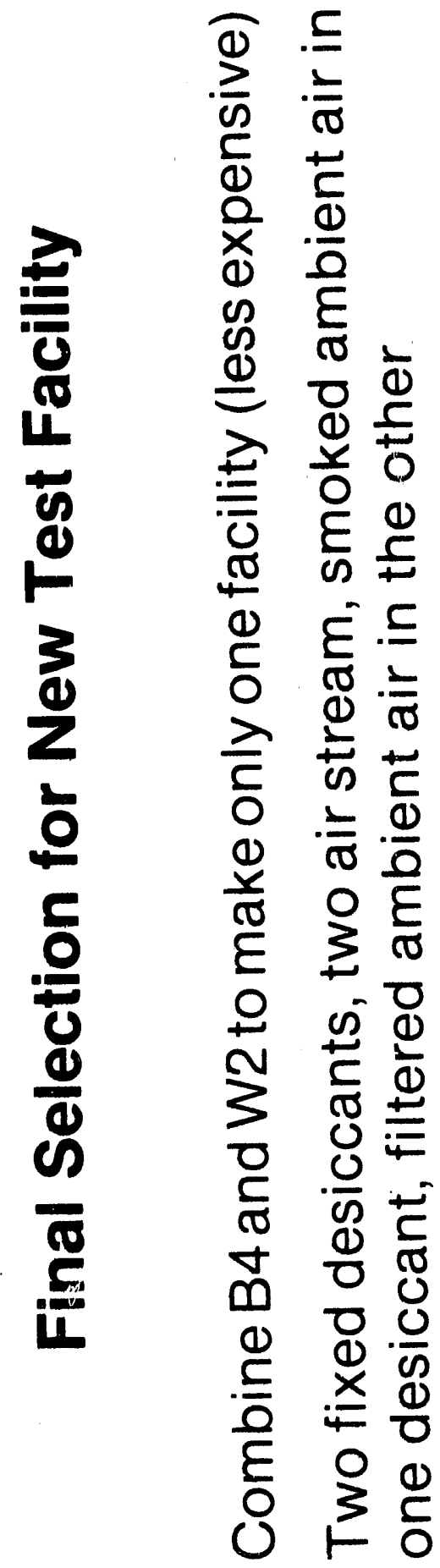




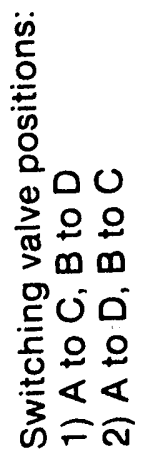

蒿:

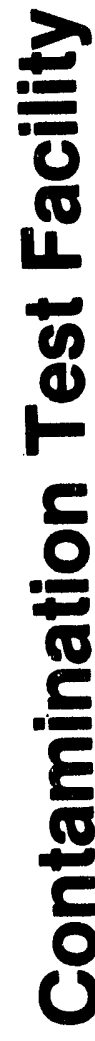
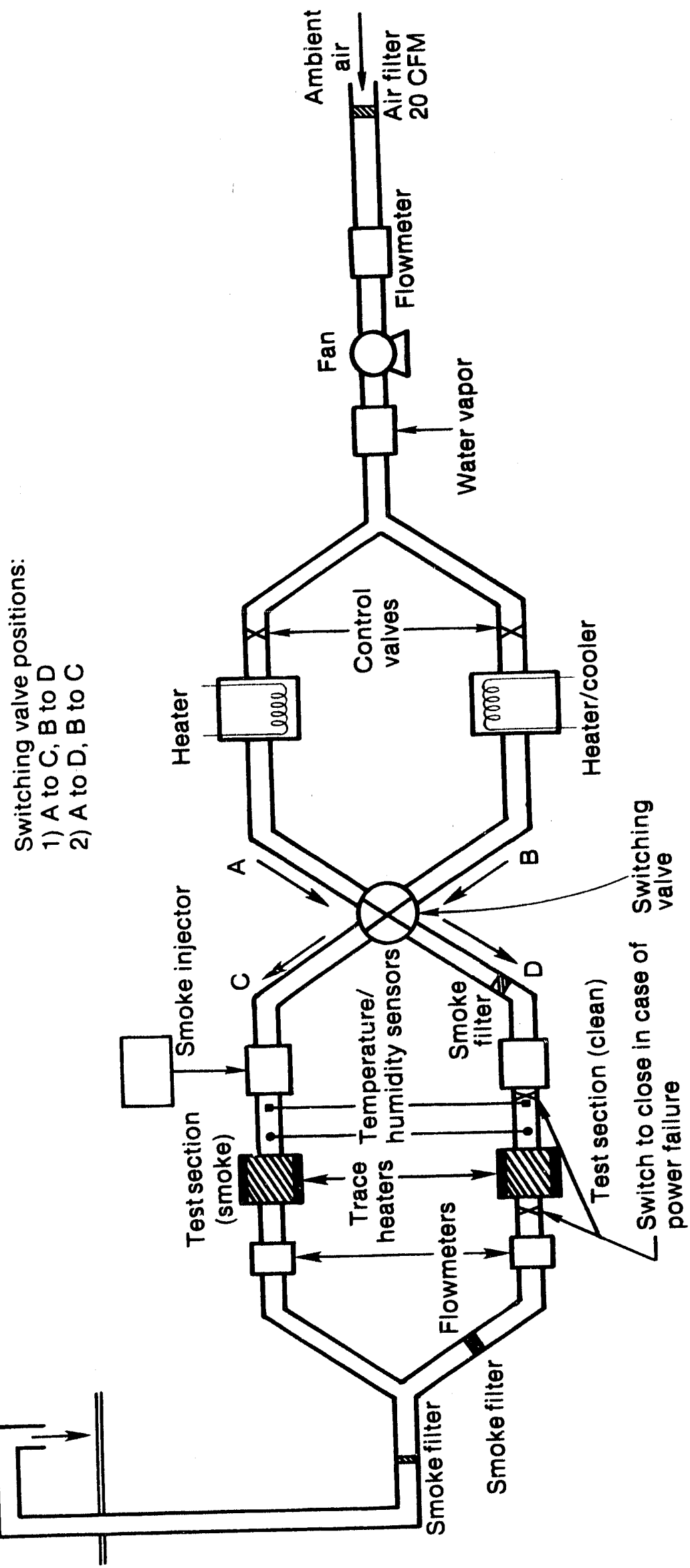


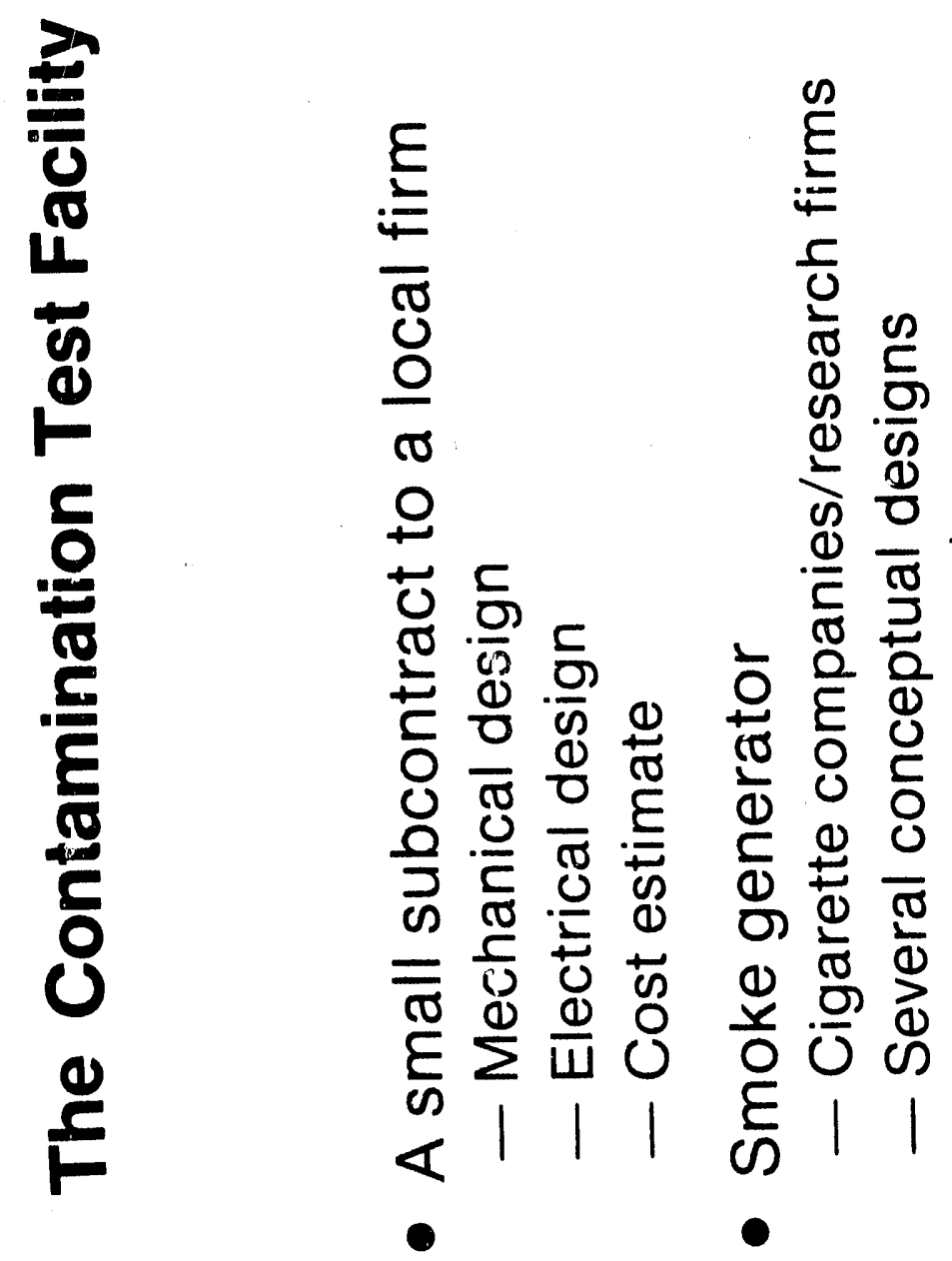




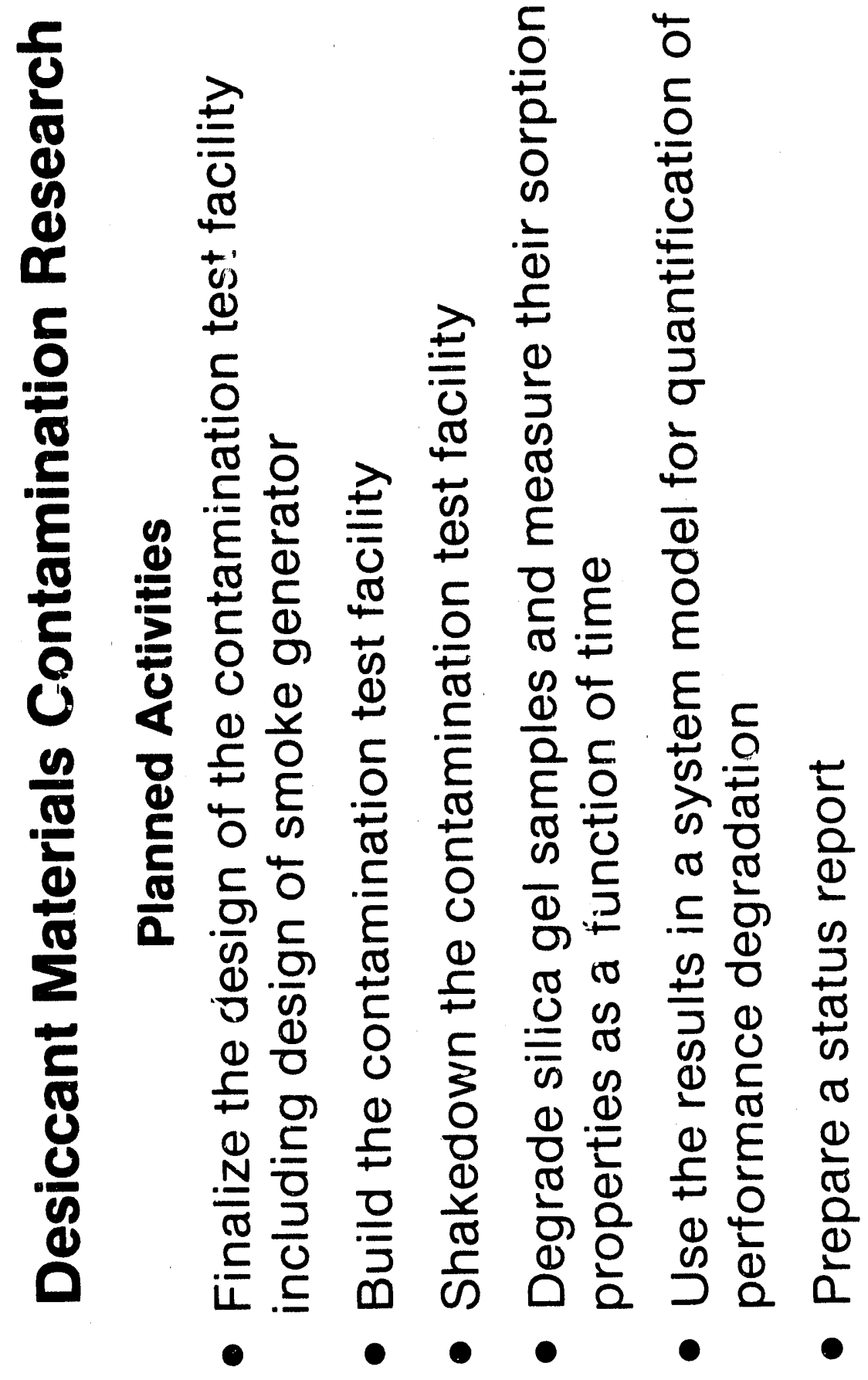



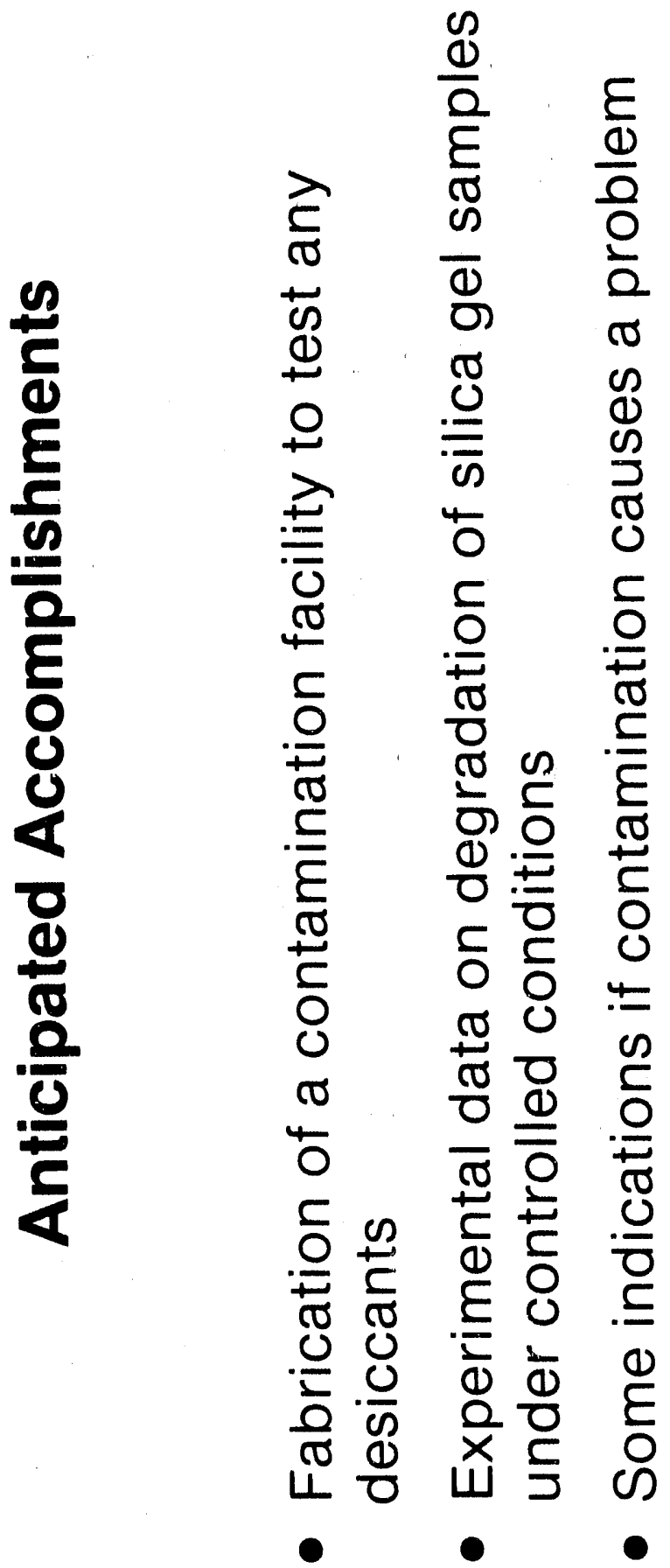


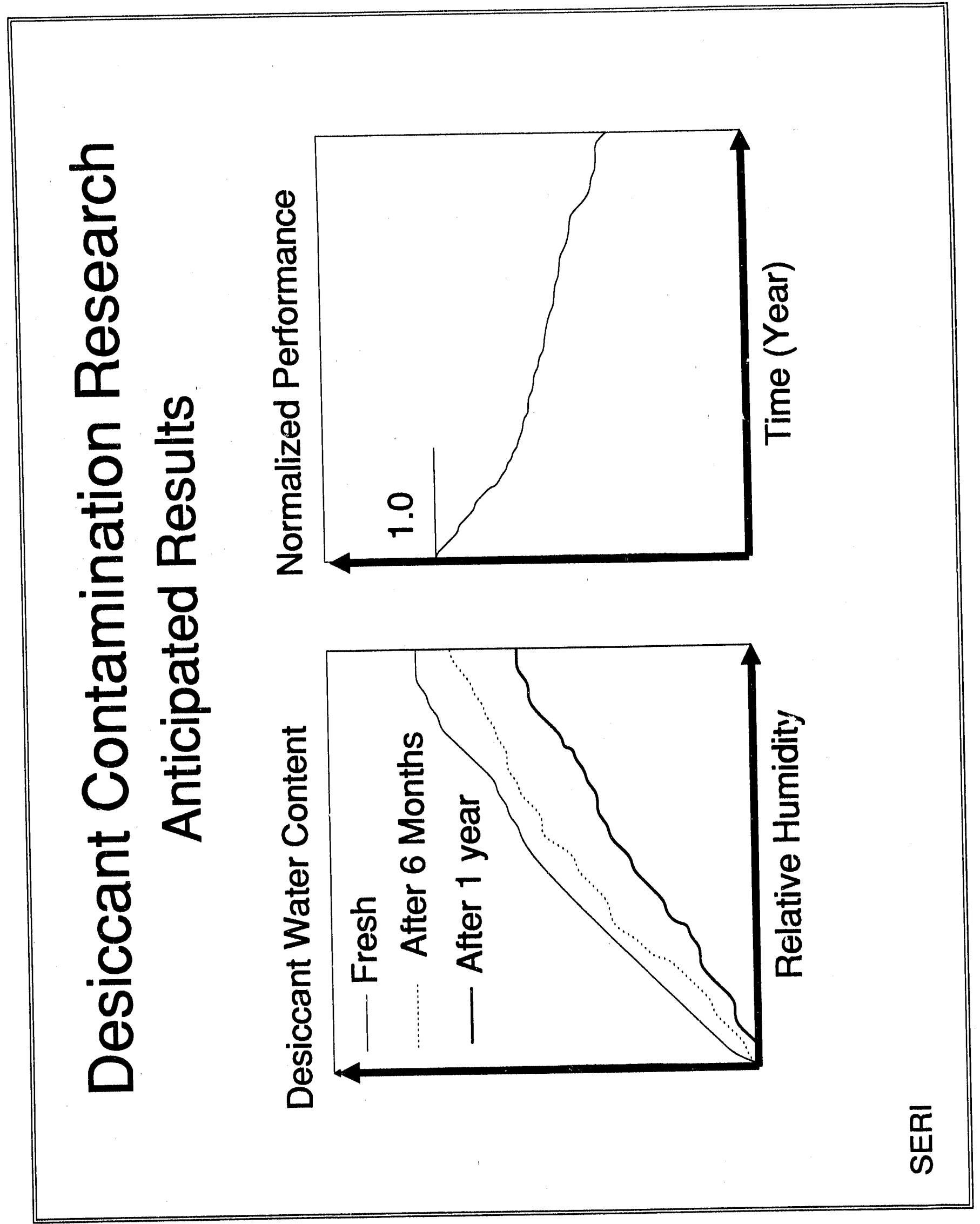




\section{APPENDIX B}

ELECTRICAL DIAGRAMS OF THE DESICCANT CONTAMINATION TEST FACILITY 


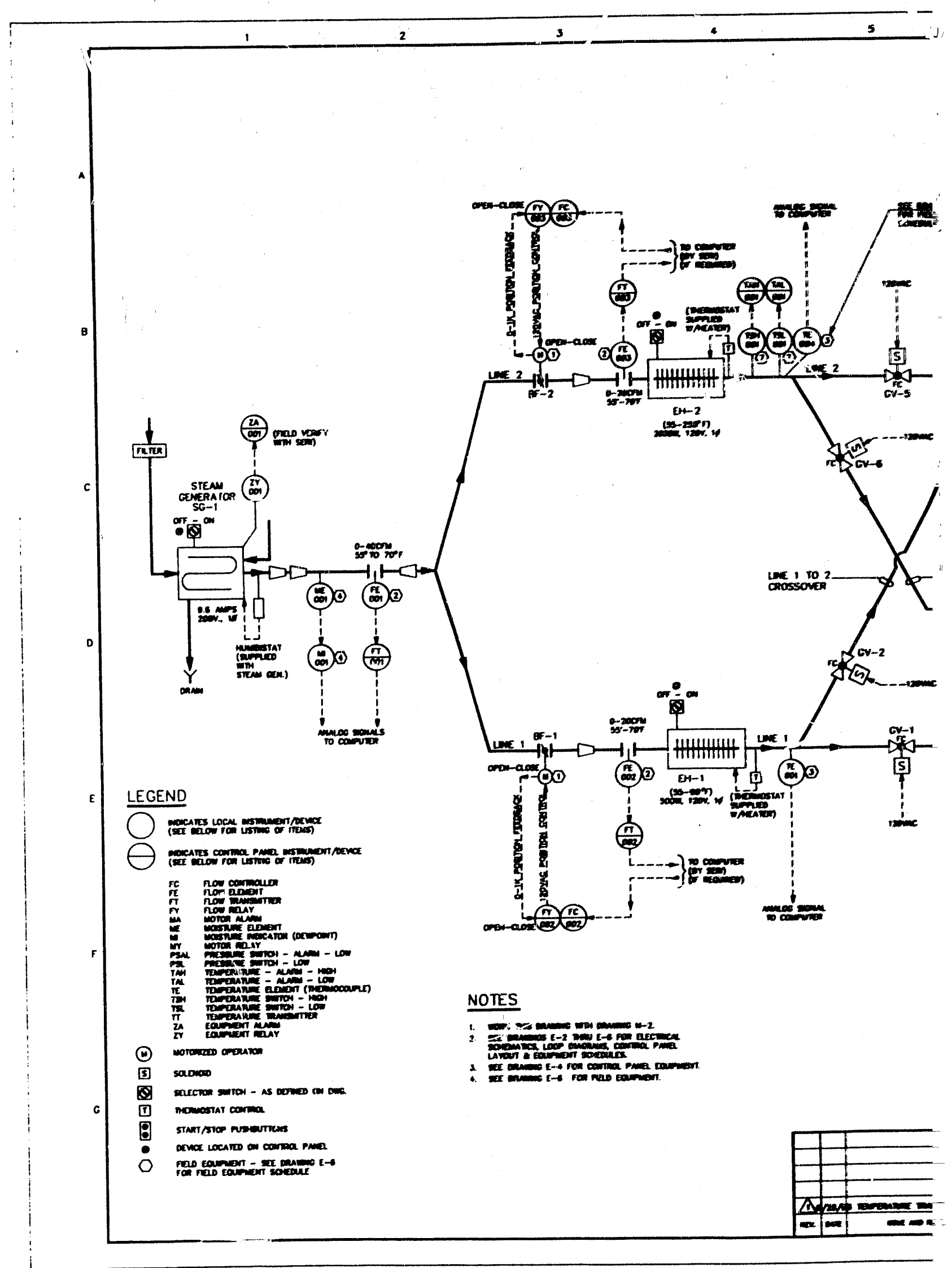


TP-3457

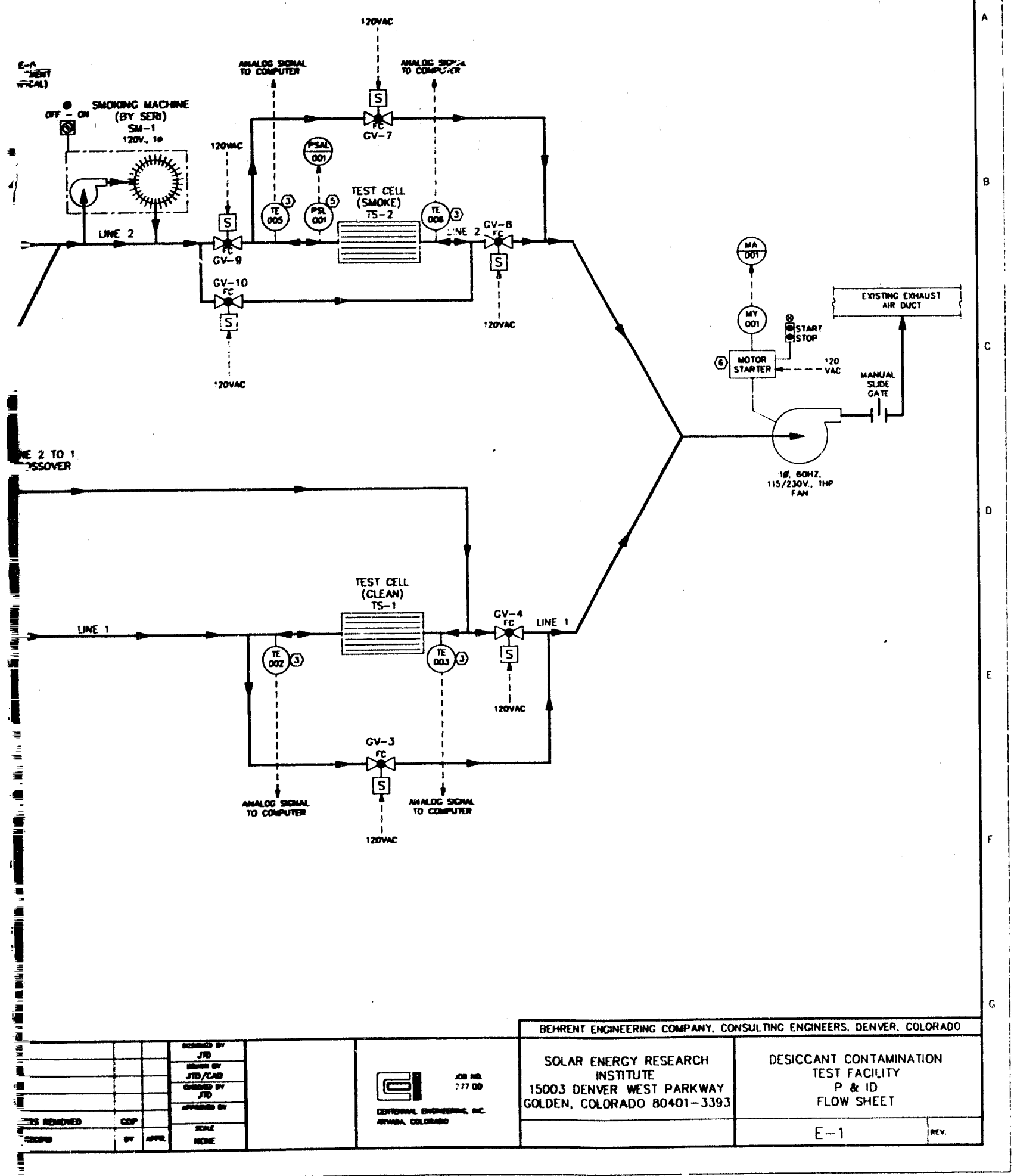

Figure B-1. Destocent contemingtten tegt fec!!ty electrical schematic_P\&ID flow sheet 


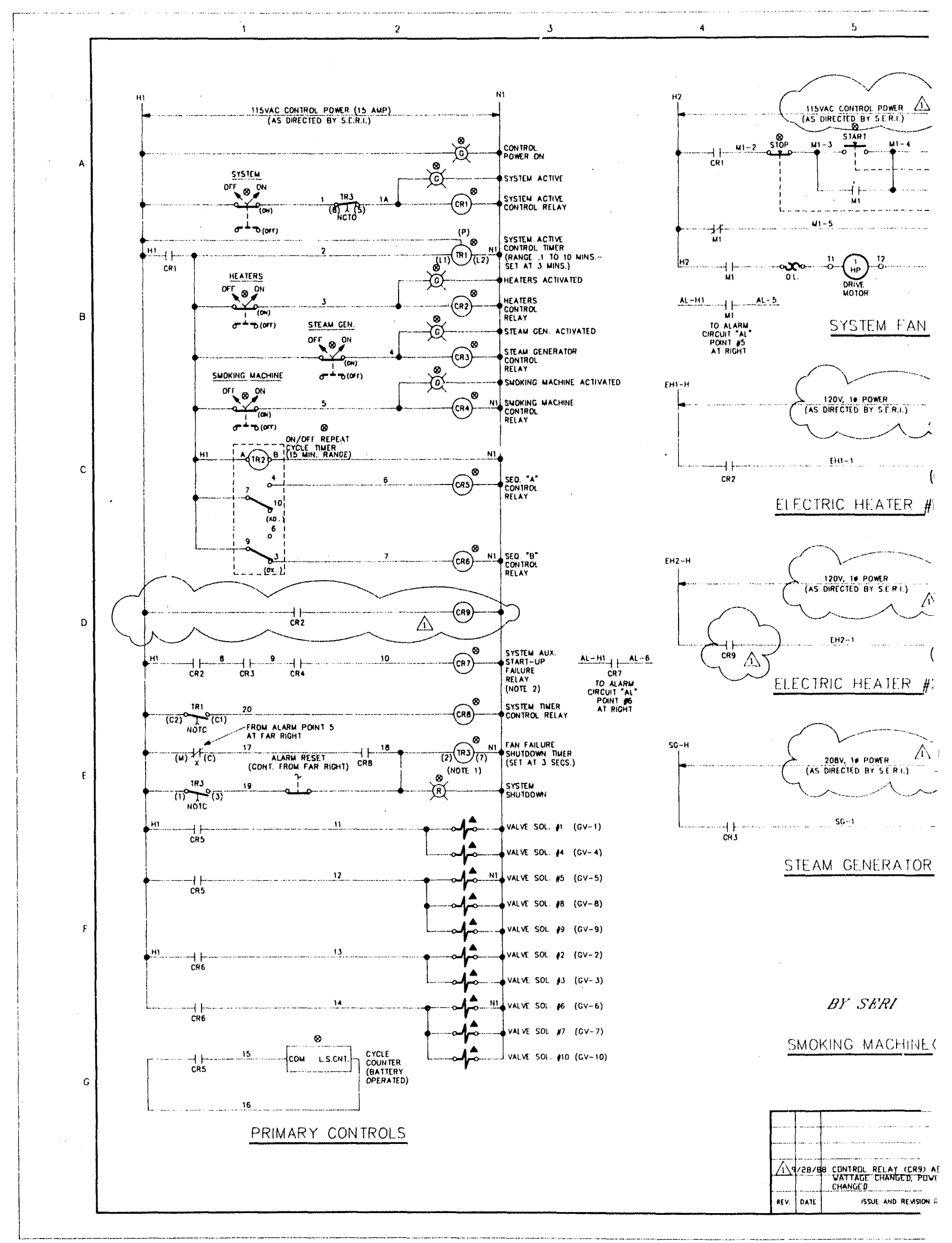



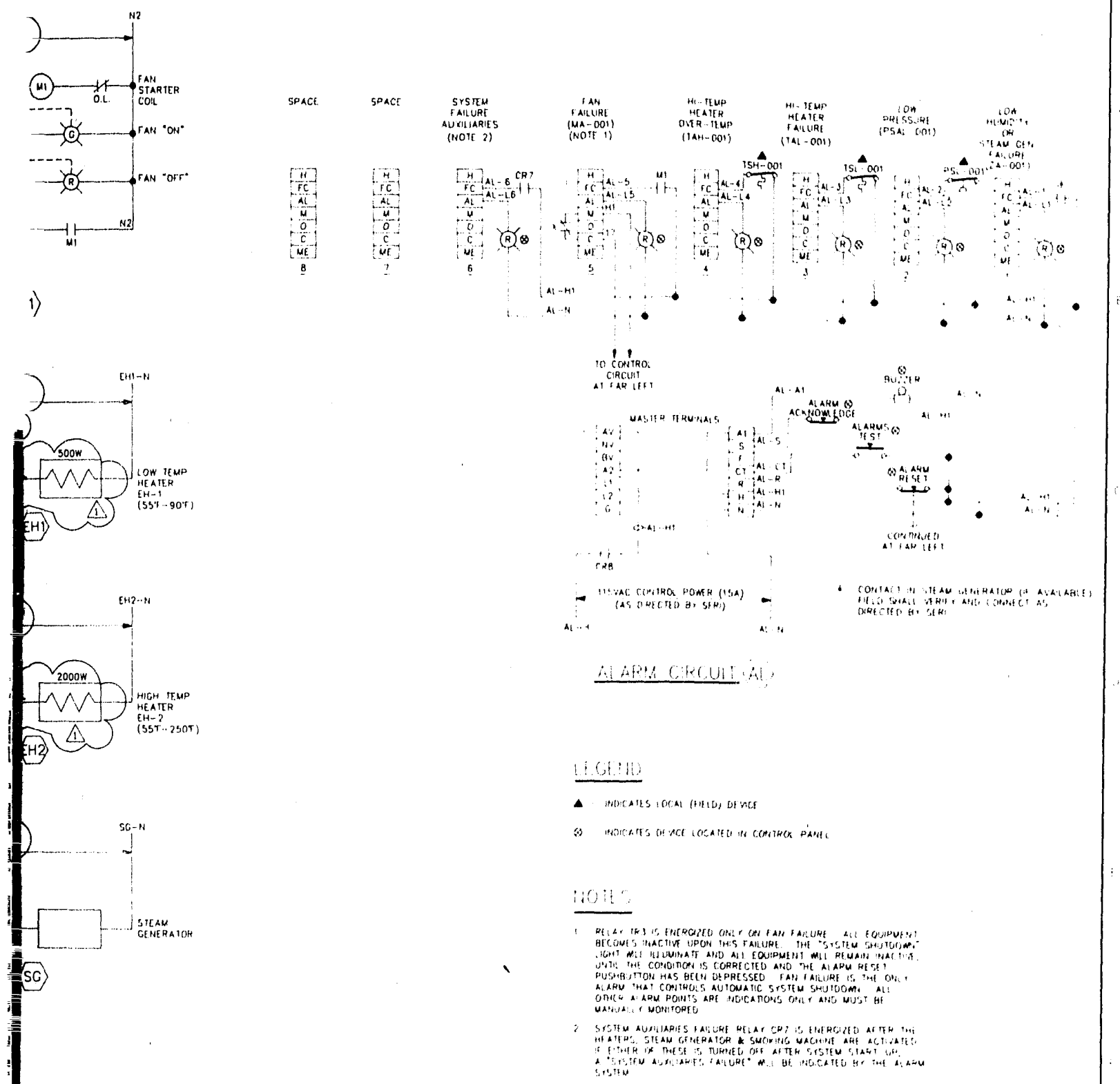

Figure B-2. Desiccant contamination test facility electrical schematic-schematic diagrams 


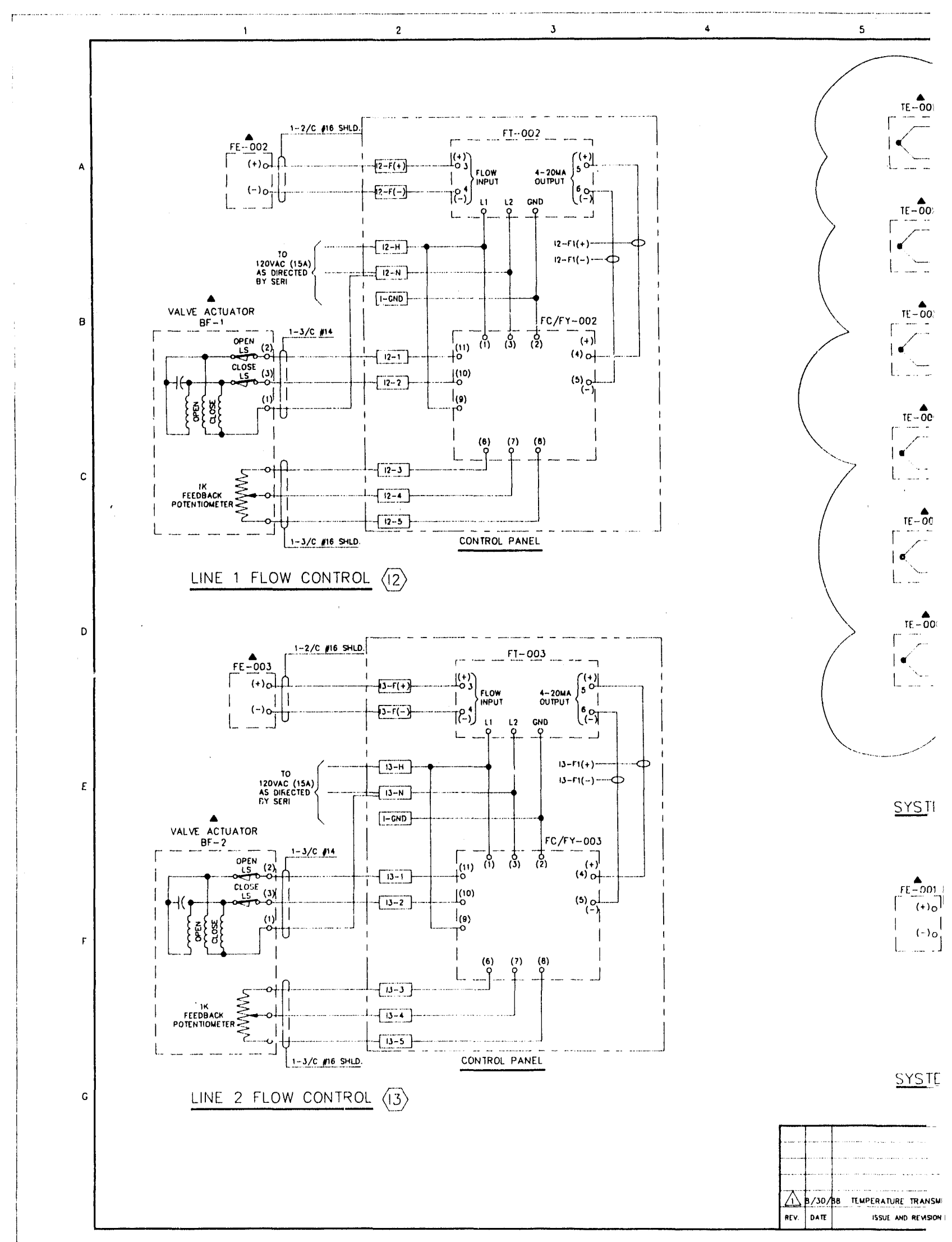




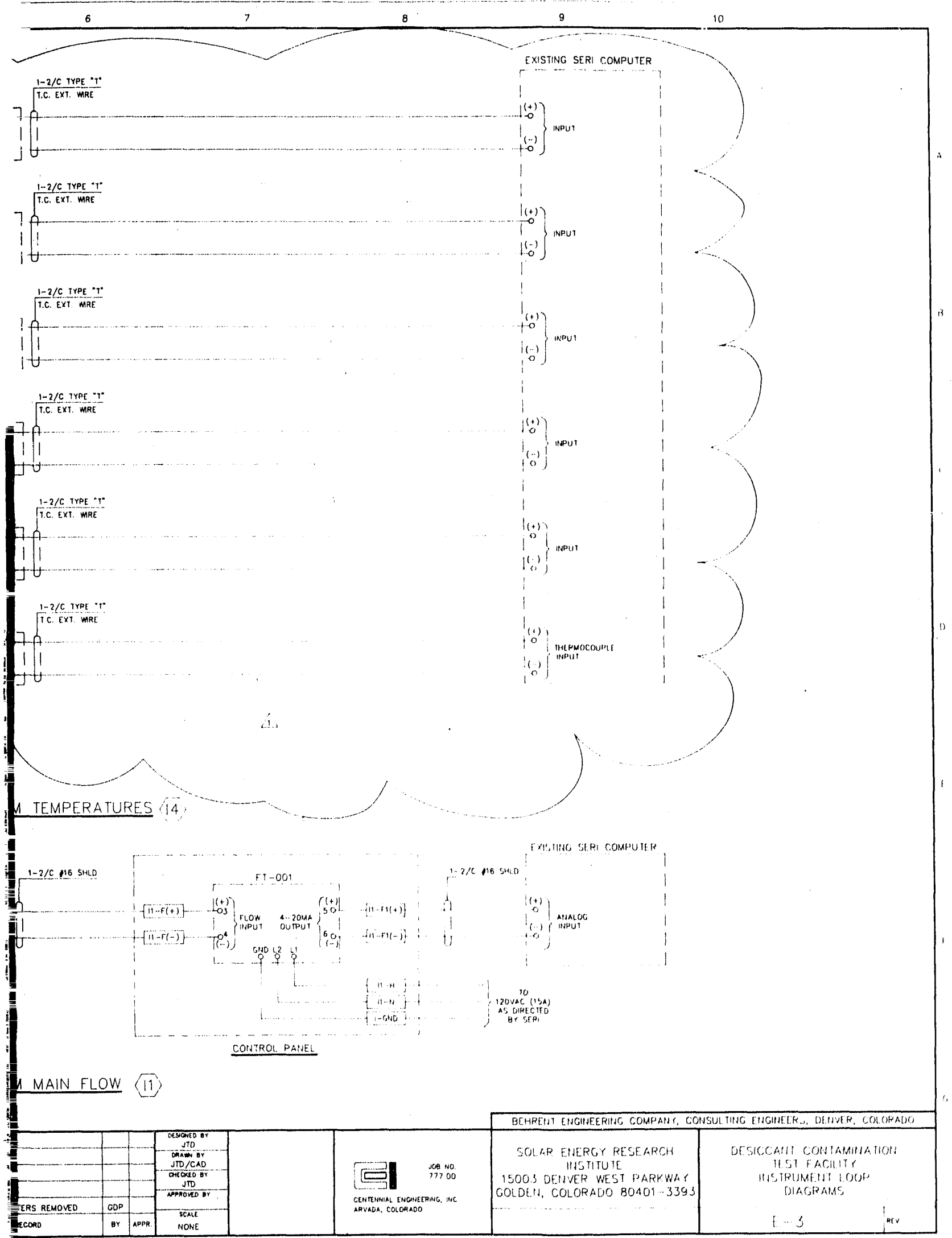

Figure B-3. Desiccant contamination test facillty electrical schematic-Instrument loop diagrams 


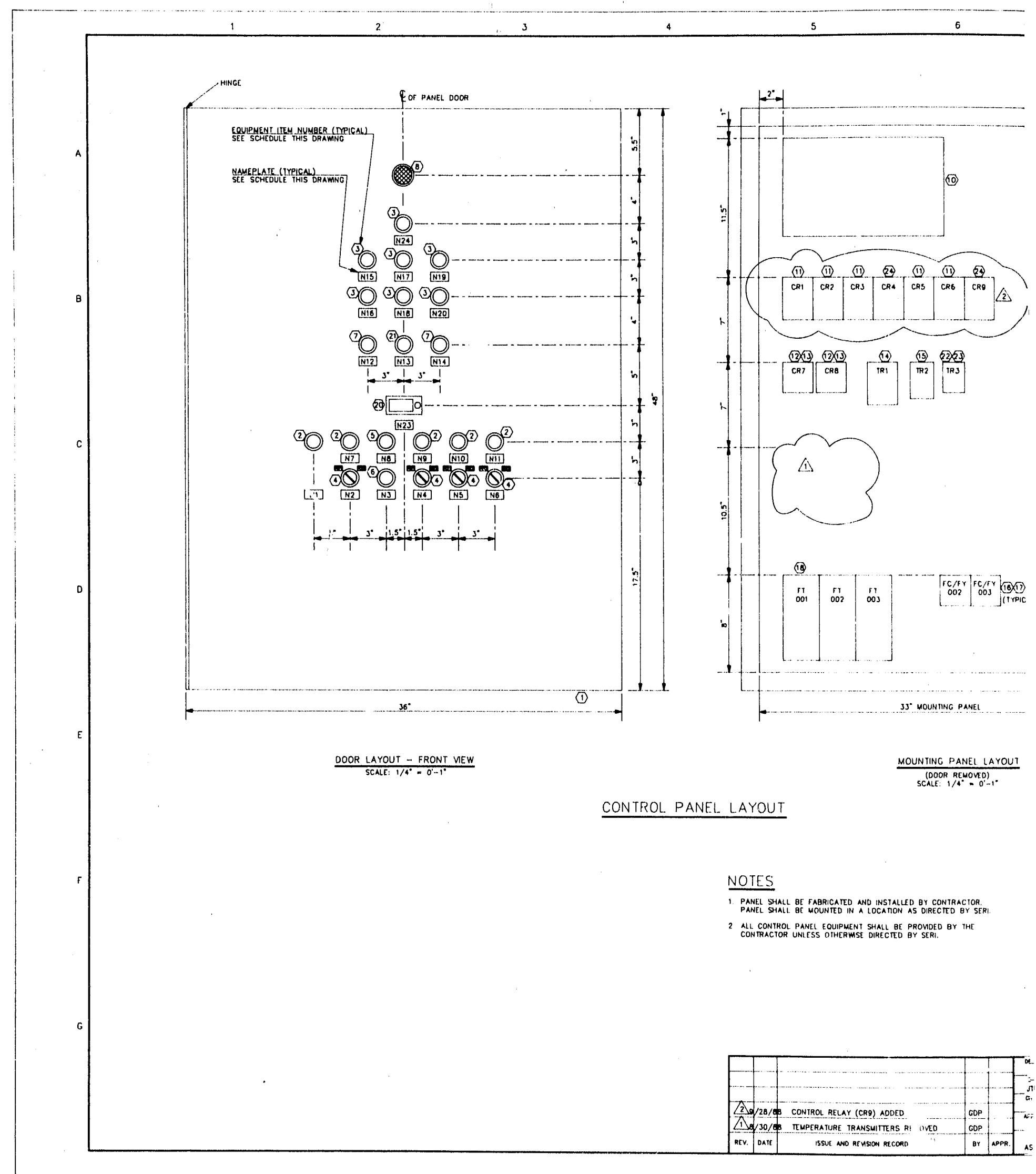




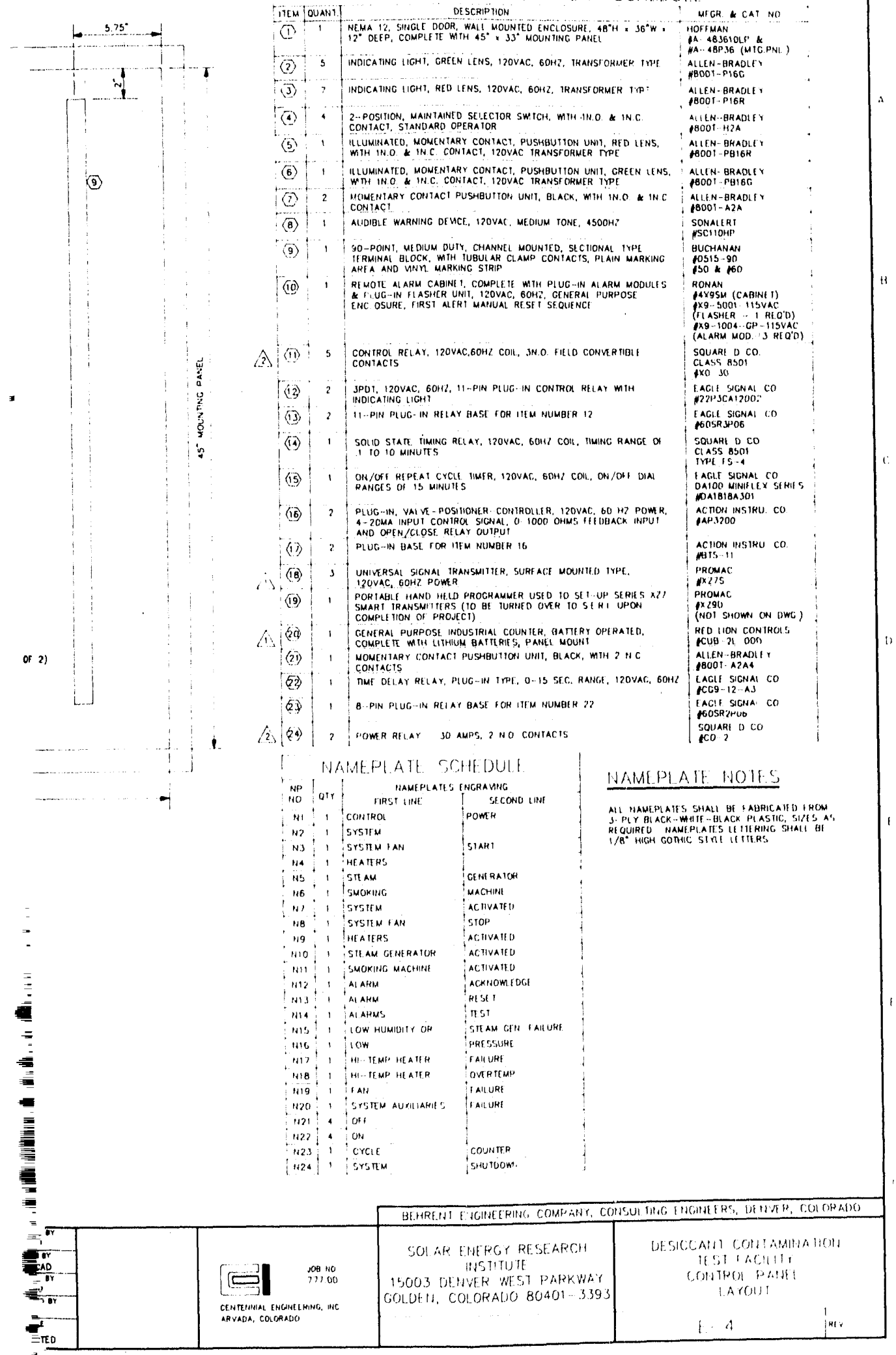
CONTROL PANEL EQUIPMENT SCHEDUUIF

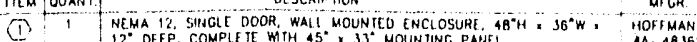

(1)

$1800 \mathrm{t}+12 \mathrm{~A}$

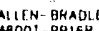

ALIST BRAOLY

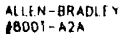

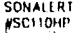

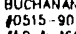

(a)

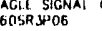

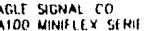

Dabibasol

shomen on DWe)

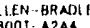

nameplatt ocheduli

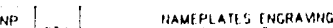

sian

ins

STIAM GRI IALUH

pressumi

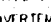

Tal.uRt

1120 : 190

$1221+1010$

ni23 1 creas

WAMEPLAIE NOIFS

TABPICAITIS:ROM J. Pr riack.

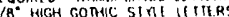




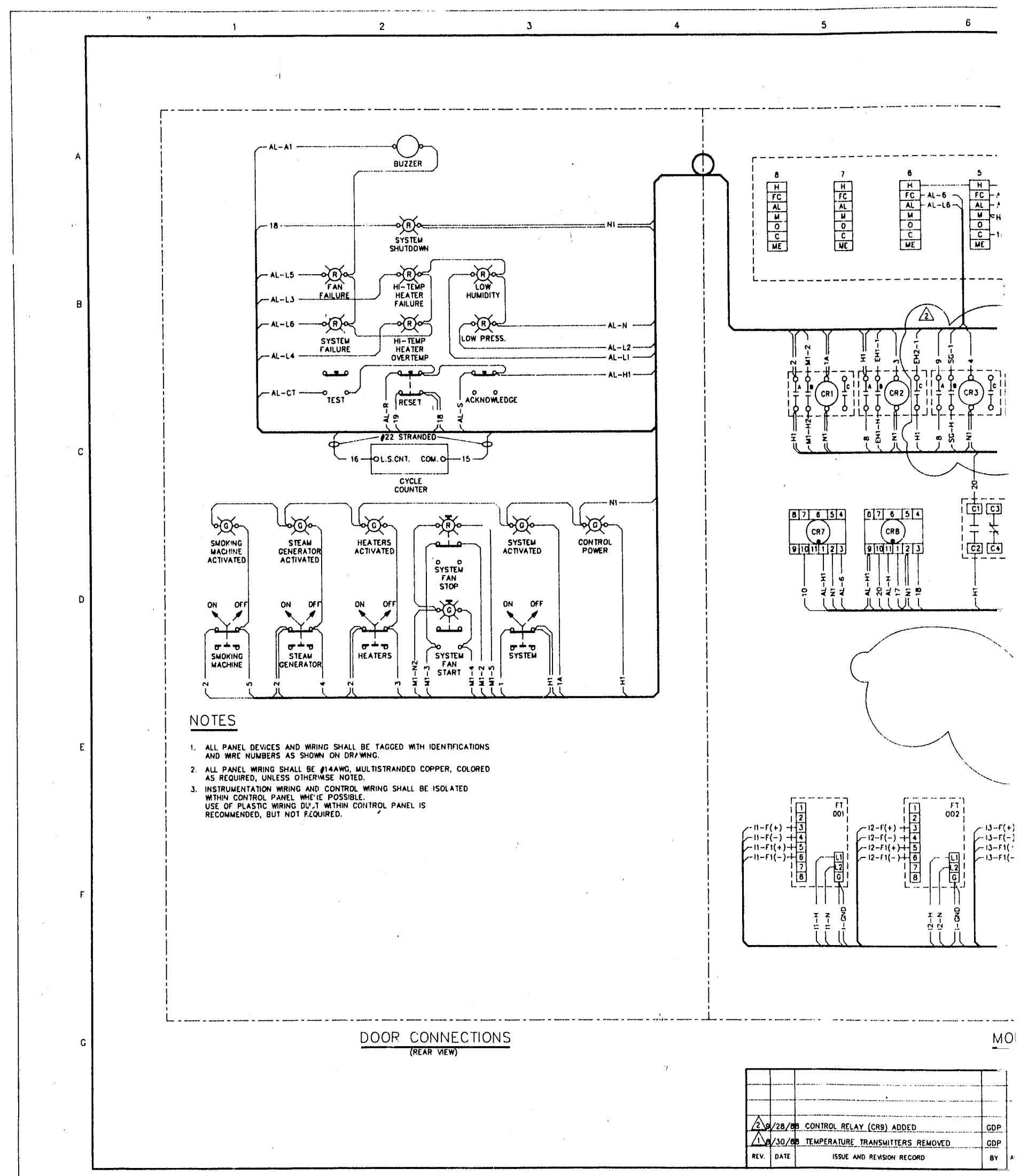




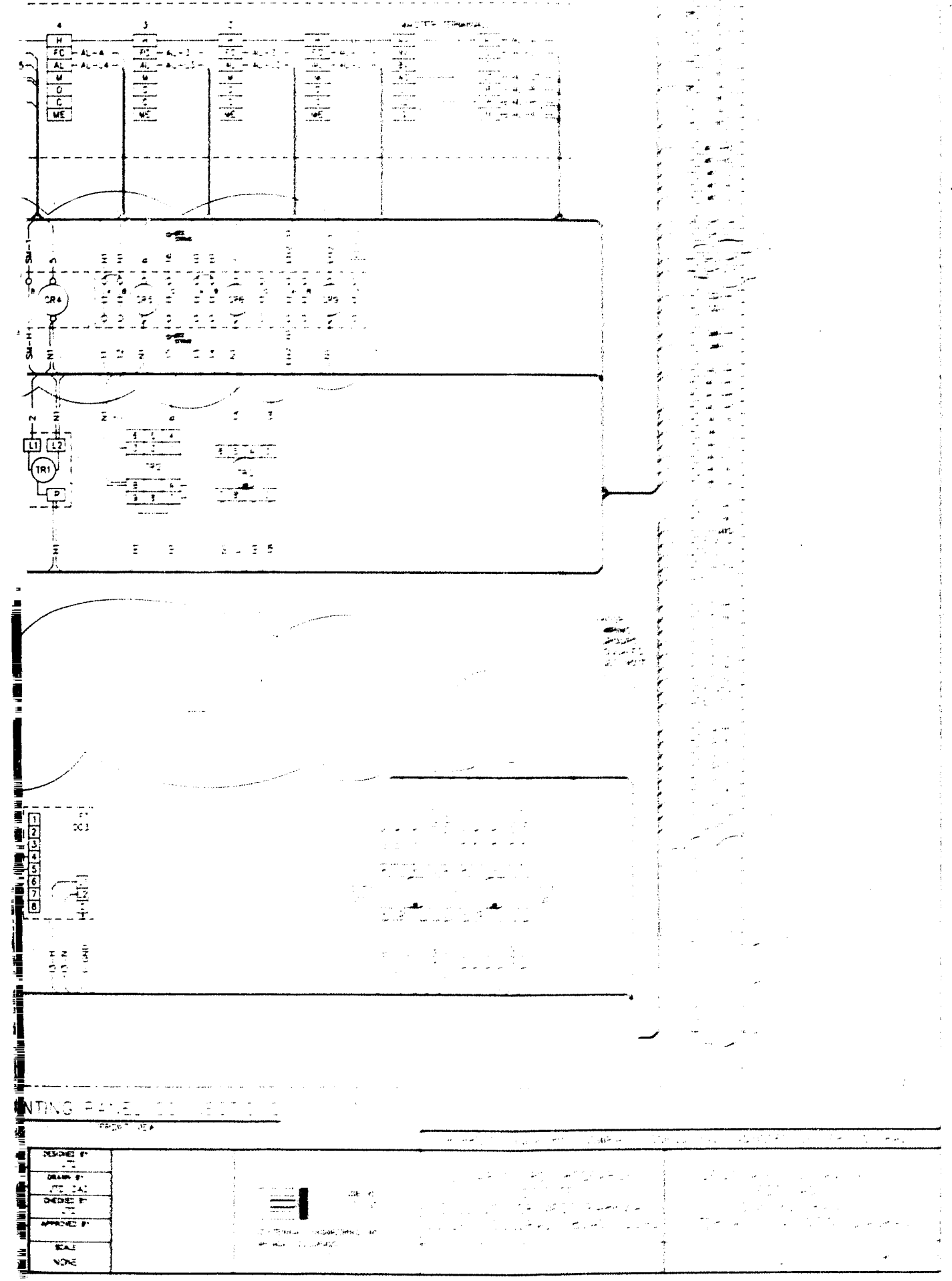

Figure B-5. Desiccant contamination test tacitity electrical schematic-control panel imternal connection diegram 


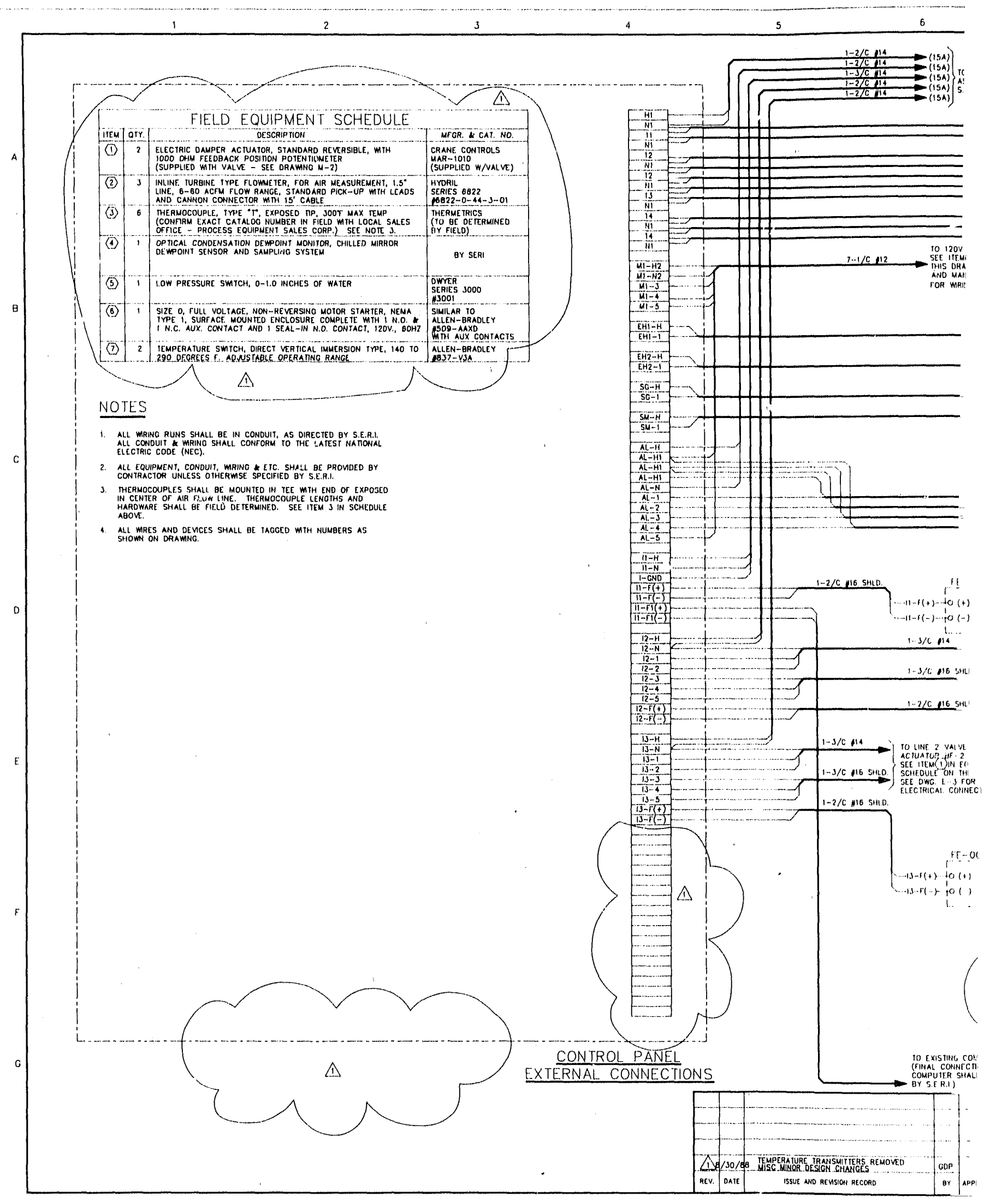




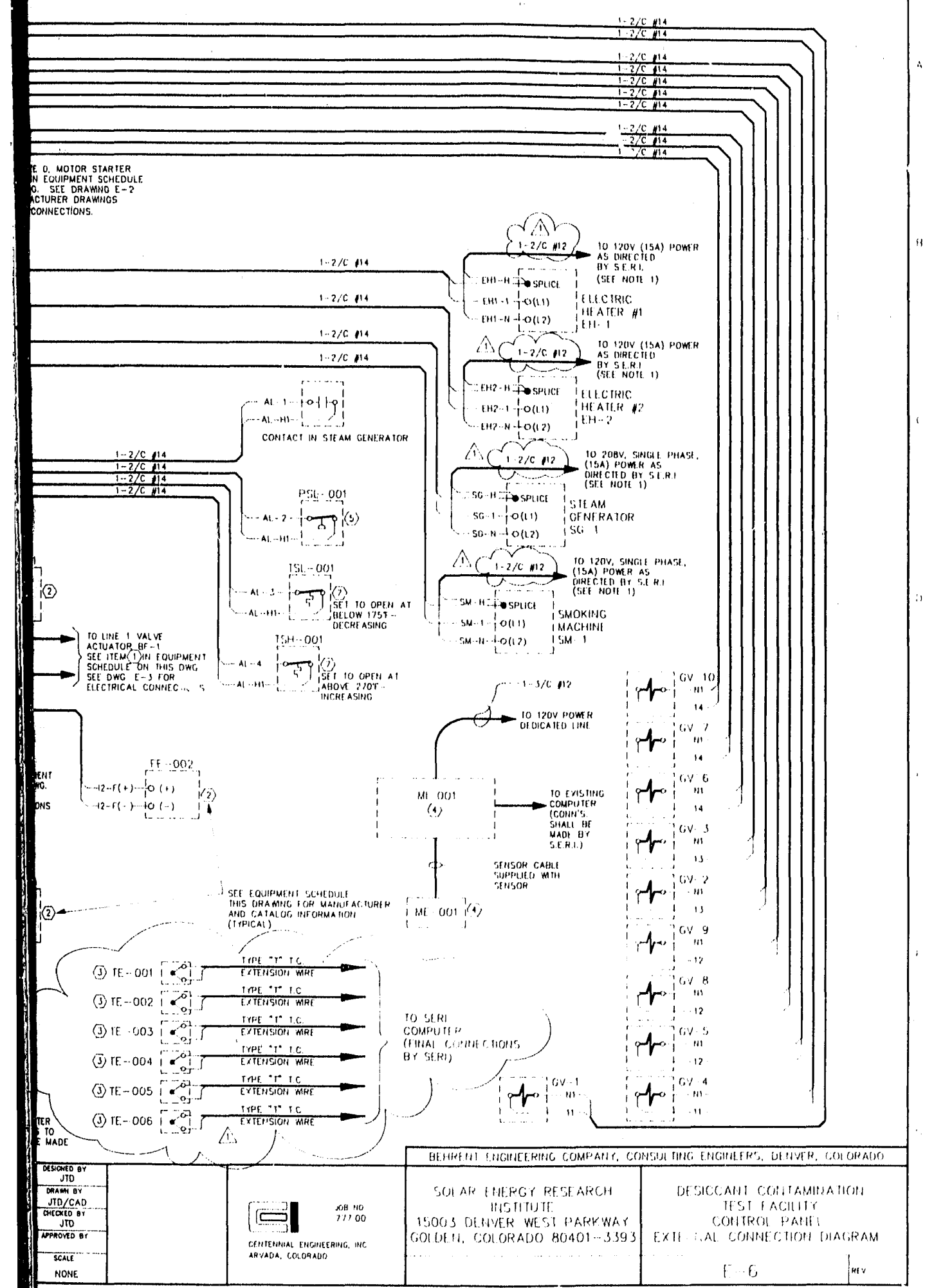

Figure B-6. Desiccant contamination test facility electrical schematlc-control panel external connectlon dlagram 


\section{APPENDIX C \\ SELECTED DISTRIBUTION LIST}

C-1 
Carl Bergt

Trane Systems Engineering Co. 6200 Troup Highway

Tyler, TX 75711

Steve Brickley

Cargocaire Engineering Corp.

79 Monroe St.

Amesbury, MA 01913

Barry Cohen

Thermal Products Division

ThermoElectron Corporation

45 First Avenue

Waltham, MA 02154

Kirk Collier

Florida Solar Energy Center

300 State Road, 401

Cape Canaveral, FL 32920

Michael Epstein

Fauske \& Associates, Inc.

162070 West 83rd Street

Burr Ridge, IL 60521

Phillip Fairey

'Morida Solar Energy Center

300 State Road, 401

Cape Canaveral, FL 32920

A. Hunter Fanney

National Bureau of Standards

Bldg. 226, Room B310

Washington, DC 20234

Stephen D. Fitch

Bry-Air

P.O. Box 795

Sunbry, OH 43074

Paul Gandhidasan

Dept of Mechanical Engineering

Texas A\&M University

College Station, TX 77843
John Goldsmith

U.S. Department of Energy

Route CE-421, Room 5H065

1000 Independence Ave., S.W.

Washington, DC 20585

William C. Griffiths

Midland Ross Corporation

P.O. Box 791

New Brunswick, NJ 08903

Robert Hasset

U.S. Department of Energy

CE 421, Room 5H-407

1000 Independence Ave., S.W.

Washington, DC 20585

Anthony Hines

1010 Engineering Building

University of Columbia

Columbia, Missouri 65211

Doug Hittle

Colorado State University

Solar Energy Applications Laboratory

Fort Collins, CO 80523

Robert Hughey

U.S. Department of Energy

San Francisco Operations Office

1333 Broadway

Oakland, CA 94612

Robert Jones

Los Alamos National Laboratory

P.O. Box 1663

Mail Stop H577

Los Alamos, NM 87545

Zalman Lavan

Illinois Institute of Technology

Department of Mechanical Engineering

Illinois Institute of Technology Center

Chicago, IL 60616 
George Lof

Colorado State University

Solar Energy Applications Laboratory

Fort Cullins, CO 80523

Esher Kweller

U.S. Department of Energy

CE-422, 5 H098

1000 Independence Ave., S.W.

Washington, DC 20585

Ian Maclaine-cross

University of New South Wales

School of Mechanical and Industrial

Engineering

P.O. Box 1

Kensington, NSW 2033 Australia

J.uin Mitchell

University of Wisconsin-Madison

Engineering Research Building

1500 Johnson Drive

Madison, WI 53706

Davor Novosel

Gas Research Institute

8600 West Bryn Mawr Avenue

Chicago, IL 60631

Steve Procter

Teledyne WaterPik

1730 East Pmspect St.

Fort Collins, CO 80525

Suresh Relvani

IIT Research Institute

10 West 35th Street

Chicago, IL 60616
D.M. Ruthven

University of New Brunswick

P.O. Box 4400

Fredericton, N.B.

CANADA E58 5A3

Ken Schultz

Honeywell Inc.

10701 Lyndale Avenue South

Bloomington, Minnesota 55420

M. Wahlig

Lawrence Berkeley Laboratories

University of California

1 Cyclotron

Berkeley, CA 94720

Byard Wood

Department of Mechanical \& Aerospace

Engineering

Arizona State University

Tempe, AZ 85287

William Worek

Department of Mechanical Engineering

$\mathrm{M} / \mathrm{C} 251$

900 Science and Engineering Offices

Box 4348

Chicago, IL 60680 


\begin{tabular}{|c|c|c|c|}
\hline Document Control Page & $\begin{array}{l}\text { 1. SERI Report No. } \\
\text { SERI/TP-254-3457 }\end{array}$ & $\begin{array}{l}\text { 2. NTIS Accession No. } \\
\text { DE91002193 }\end{array}$ & 3. Recipient's Áccession No. \\
\hline \multirow{2}{*}{\multicolumn{3}{|c|}{$\begin{array}{l}\text { 4. Title and Subtitle } \\
\text { Desiccant Contamination Research: Report on the Desiccant Contamination Test } \\
\text { Facility }\end{array}$}} & $\begin{array}{l}\text { 5. Publication Date } \\
\text { July } 1991\end{array}$ \\
\hline & & & 6. \\
\hline \multicolumn{3}{|c|}{$\begin{array}{l}\text { 7. Author(s) } \\
\text { Ahmad A. Pesaran and Carl E. Bingham }\end{array}$} & 8. Performing Organization Rept. No. \\
\hline \multirow{2}{*}{\multicolumn{3}{|c|}{$\begin{array}{l}\text { 9. Performing Organization Name and Address } \\
\text { Solar Energy Reset ch Instituie } \\
1617 \text { Cole Blvd. } \\
\text { Golden, CO } 80401\end{array}$}} & $\begin{array}{l}\text { 10. ProjectTaskWork Unit No. } \\
\text { BE112043 }\end{array}$ \\
\hline & & & $\begin{array}{l}\text { 11. Contract (C) or Grant (G) No. } \\
\text { (C) } \\
\text { (G) }\end{array}$ \\
\hline \multicolumn{3}{|c|}{ 12. Sponsoring Organization Name and Address } & $\begin{array}{l}\text { 13. Type of Report \& Period Covered } \\
\text { Technical Report }\end{array}$ \\
\hline \multicolumn{4}{|l|}{ 15. Supplementary Notes } \\
\hline \multicolumn{4}{|c|}{$\begin{array}{l}\text { 16. Abstract (Limit: } 200 \text { words) } \\
\text { The objective of this project is to fabricate a test facility to investigate the impact of desiccant contamination from airbornt } \\
\text { pollutarts on the sorption properties of desiccant materials. The results will be used to estimate the impact of desiccan } \\
\text { degradation on the performance of solar desiccant cooling systems. This report focuses only on the effort to build the desiccan } \\
\text { contamination test facility. The experimental results are documented in FY } 1989 / 1990 \text { reports. }\end{array}$} \\
\hline \multicolumn{4}{|c|}{$\begin{array}{l}\text { 17. Document Analysis } \\
\text { a. Descriptors } \\
\text { desiccant contamination ; desiccant degradation ; sorption ; desiccant cooling ; cigarette smoke ; thermal cycling }\end{array}$} \\
\hline \multicolumn{4}{|l|}{$\begin{array}{l}\text { c. UC Categories } \\
231\end{array}$} \\
\hline \multirow{2}{*}{\multicolumn{2}{|c|}{$\begin{array}{l}\text { 18. Availabllity Statement } \\
\text { National Technical Information Service } \\
\text { U.S. Department of Commerce } \\
\text { 5285 Por Royal Road } \\
\text { Springfield. VA } 22161\end{array}$}} & & $\begin{array}{l}\text { 19. No. of Pages } \\
114\end{array}$ \\
\hline & & & $\begin{array}{l}\text { 20. Price } \\
\text { A06 }\end{array}$ \\
\hline
\end{tabular}

Form No. 0069E (6-30-87) 

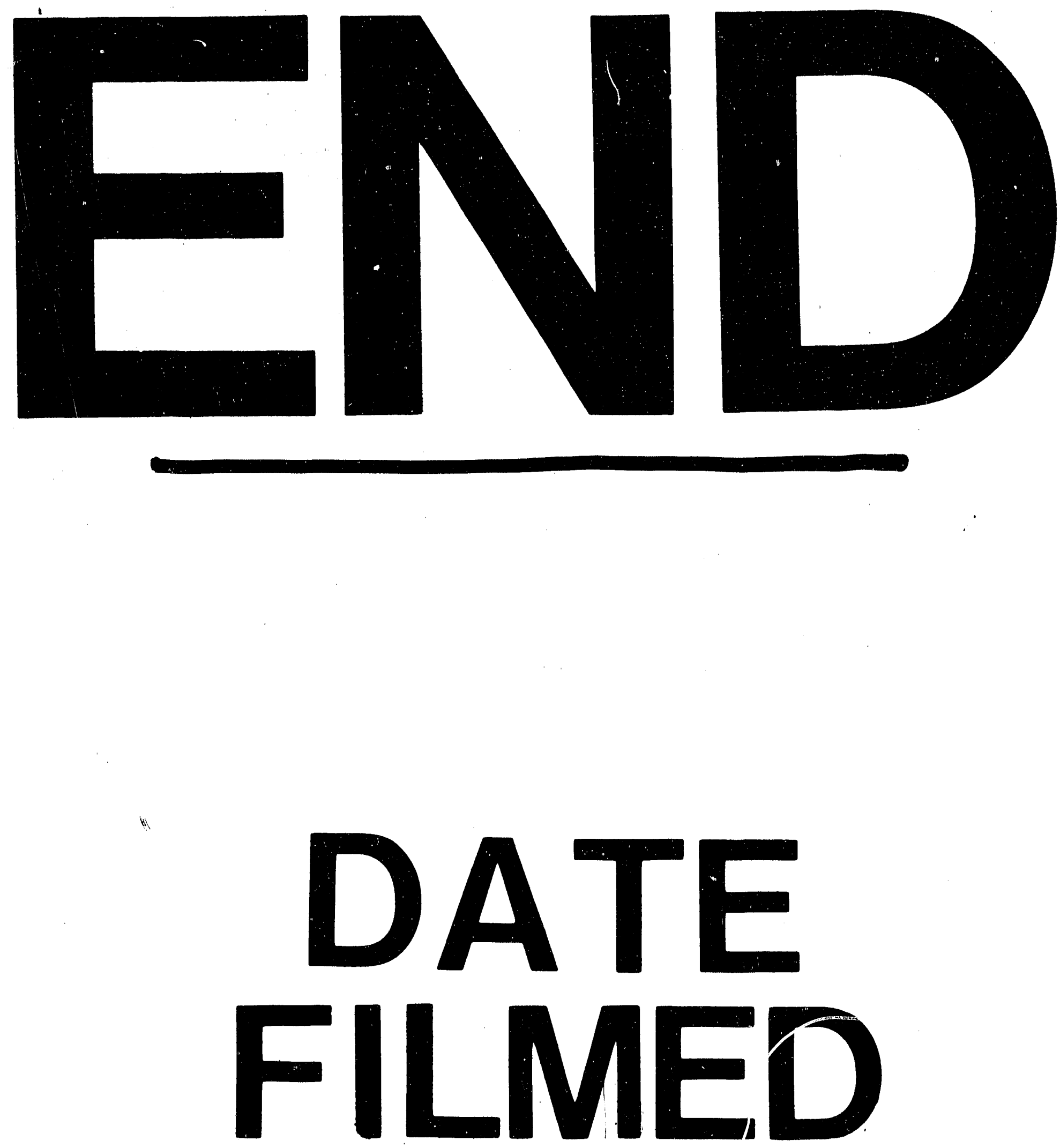

$10 \mid 15 / 91$

$I$ 

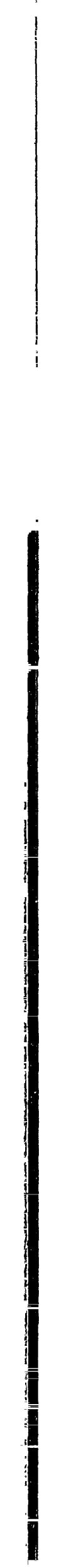